\title{
Revisiting a Historic Manuscript: Vere Huddleston's Report on East Place (3CL21) Excavations
}

Mary B. Trubitt

Arkansas Archeological Survey, HSU Research Station

Linda Evans

Follow this and additional works at: https://scholarworks.sfasu.edu/ita

Part of the American Material Culture Commons, Archaeological Anthropology Commons, Environmental Studies Commons, Other American Studies Commons, Other Arts and Humanities Commons, Other History of Art, Architecture, and Archaeology Commons, and the United States History Commons

Tell us how this article helped you.

This Article is brought to you for free and open access by the Center for Regional Heritage Research at SFA ScholarWorks. It has been accepted for inclusion in Index of Texas Archaeology: Open Access Gray Literature from the Lone Star State by an authorized editor of SFA ScholarWorks. For more information, please contact cdsscholarworks@sfasu.edu. 
Revisiting a Historic Manuscript: Vere Huddleston's Report on East Place (3CL21) Excavations

\section{Creative Commons License}

\section{(c) (1) (8)}

This work is licensed under a Creative Commons Attribution-NonCommercial 4.0 International License 


\title{
REVISITING A HiSTORIC MANUSCRIPT: VERE Huddleston's Report on EAst Place (3CL21) EXCAVATIONS
}

\section{Mary Beth Trubitt and Linda Evans}

\begin{abstract}
Vere L. Huddleston was one of several amateur archaeologists who excavated Caddo sites in Clark County, Arkansas, during the 1930s and 1940s. Huddleston took better notes about the sites and contexts of his finds than many of his contemporaries. His large collection of artifacts is now part of the Joint Educational Consortium's Hodges Collection in Arkadelphia. A manuscript on his excavations at the East Place - the largest Caddo mound group in Clark County - is presented here with new vessel documentation and grave lot information. Since many of these artifacts have appeared in previous publications with little description, this work provides context for interpreting the site and its placement in the Caddo Indian history of this region.
\end{abstract}

\section{Editors' Introduction}

Ancestral Caddo Indians lived and farmed along the Ouachita, Caddo, and Little Missouri rivers in Clark County, Arkansas, between at least 1100 and 1700 A.D. (Early 2002a, b, c, d; Early, ed., 1993). Large populations in the Mid-Ouachita region during this time are evidenced by the large numbers of recorded mounds, sites, and cemeteries (Early 1982; Girard et al. 2014; Trubitt 2012a, b). The archaeological residues of these past communities have attracted interest and research for over two centuries. In 1804, William Dunbar and George Hunter, charged by President Thomas Jefferson to lead an expedition up the Ouachita River, stopped at a saline near present-day Arkadelphia. Digging two holes there, the men found "several pieces of Indian earthen pots, probably used by them in making salt," (Berry et al. 2006:87; archaeological sites such as Bayou Sel, 3CL27, and Hardman, 3CL418, were later recorded in this vicinity, Early, ed., 1993).

Archaeological sites and the Caddo pottery in this area drew the attention of museums and collectors across the country, and digging was viewed as a source of income to some residents even before the Depression. A note by Vere Huddleston relates that "according to L. E. Tenneson of Arkadelphia, he and another student of Henderson Brown (College) excavated enough pottery from these sites in the 1890s and sold it to a museum in Chicago, to pay their way through college," (Hodges Collection, SG 41-04). Some farmers would find artifacts while plowing their fields, and often the pots would be destroyed. Many pots were dug from burial mounds and sold to collectors (Evans 2011:3).

During the Depression, a group of amateur archaeologists from Arkadelphia, Arkansas, made attempts to preserve these artifacts, keep them in this area, and make a record of the sites where they were found. Vere Huddleston, Robert Proctor, Charlie Richardson, as well as Dr. Thomas L. and Charlotte Hodges of Bismarck, were important figures in the history of Caddo archaeology in Arkansas (Girard et al. 2014). Some of our knowledge of this pottery, these archaeological sites, and the Caddo Indians who once lived in Clark County comes as a result of this Depression-era work by amateurs who not only preserved the pottery, but also took notes on their excavations. At this time, the concept of stewardship was in its early development, but in some cases these amateurs were early adherents to many of the ethical principles that American archaeologists follow today (Early 1986; Evans 2012). Robert Proctor, Charlie Richardson, and others donated 
many of the artifacts they collected to the Henderson State University (HSU) Museum, under the directorship of Dr. P. G. Horton in the 1950s. Dr. Cynthia Weber and Dr. Ann Early managed the museum between the 1970s and 1990s as part of their duties as Arkansas Archeological Survey's HSU Research Station archaeologists, and researched and documented Caddo vessels in the collections (e.g., Early 2012; Weber 1972). Since the HSU Museum closed, its American Indian artifact collection has been on loan to the Historical Arkansas Museum in Little Rock (Historic Arkansas Museum 2014).

Vere Huddleston was one of the amateur archaeologists active in Clark County during the 1930s-1940s (Figure 1). "Mr. Huddleston was the only member of his group to keep substantive records of his discoveries, and Huddleston's notes, along with his artifacts, are another invaluable and irreplaceable corpus of primary data about regional archeology," (Early 1986:4). After Huddleston's death in 1946, his collection of pottery and extensive site notes and papers were sold to Dr. and Mrs. Hodges. The Hodges collection was acquired by the Joint Educational Consortium (JEC) in 1977, and has been curated by the Arkansas Archeological Survey's HSU Research Station ever since (Early 1978, 1986; Trubitt 2007). Among Huddleston's notes, now in the HSU Archives, was an unpublished article on his excavations at the East Place, a multiple mound site now recorded as 3CL21. The lack of published data about this important site led us to revisit this manuscript in an attempt to glean new information about the archaeology of this region.

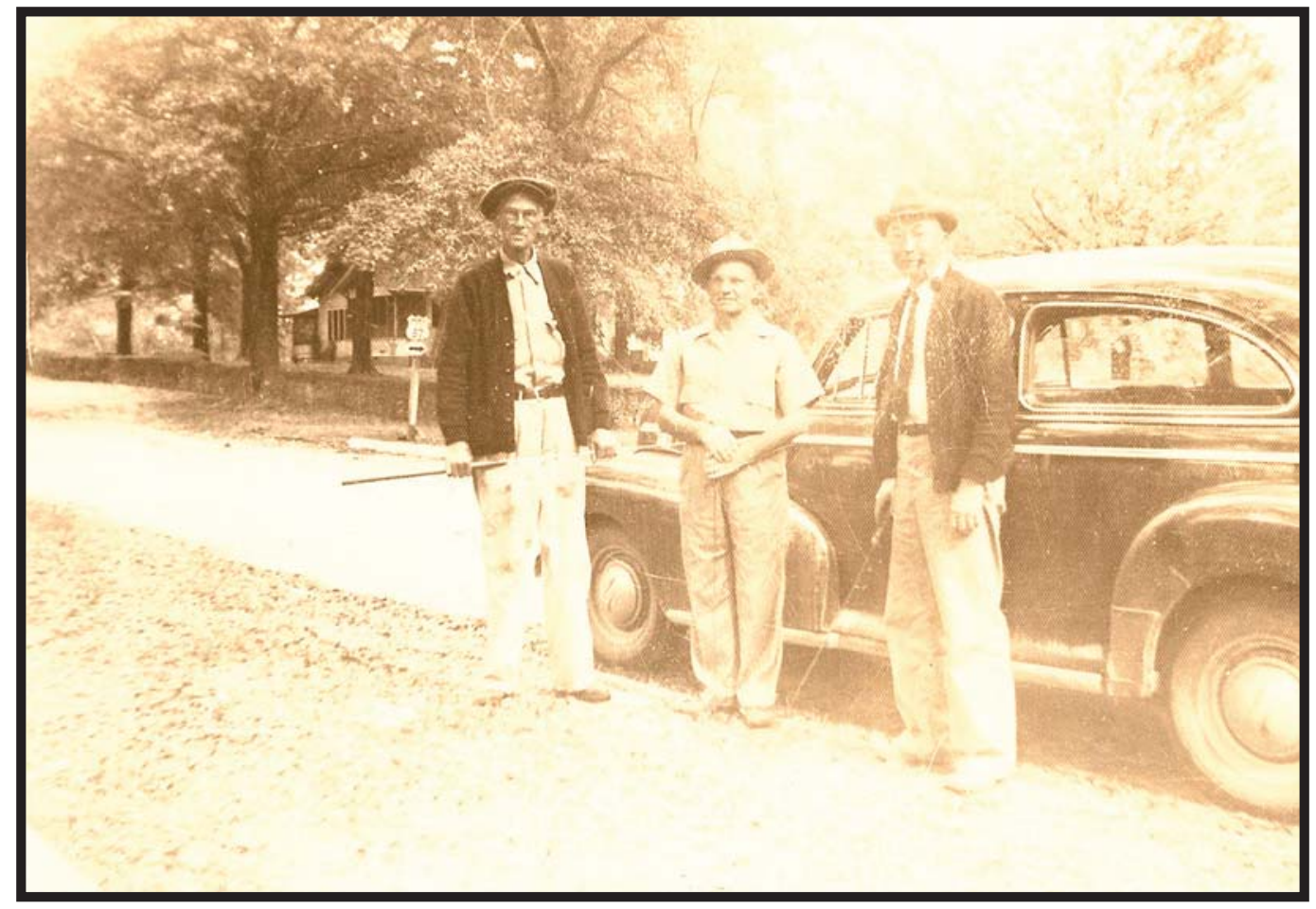

Figure 1. The Three Amateur Archeologists of Arkadelphia, 1940 (inscription on reverse also identifies, left to right, Charles Richardson, artist, Vere L. Huddleston, principal, Arkadelphia High School, and Prof. Robert Proctor, HSTC; Henderson State University Archives, Hodges Collection, SG 41/04 F7).

Vere Huddleston was born on the $23^{\text {rd }}$ of December, 1898, to Minnie C. and Flemon Huddleston, farmers who lived in Hale, in Garland County, Arkansas (Evans 2012:14). He married Mary in 1922, and by the 1930 census, he was a teacher in a public school in Arkadelphia, Arkansas. At the time of his death in 1946, he was the principal of Arkadelphia High School (Evans 2012:14). He was "an authority on Arkansas Indians, particularly the Caddo tribe ... and his collection of Indian relics included several thousand individual items, including 1,000 pieces of pottery which had been catalogued. Mr. Huddleston was one of the pioneer archaeologists of the Caddo Indians," (Richter 1992:564). Huddleston (1943) published one article, "Indians in Clark County," in the Arkansas Historical Quarterly. 
Huddleston's artifact collection and notebooks became part of the Hodges collection after his death, and Dr. and Mrs. Hodges included the Huddleston material (then tabulated at 400 vessels) in their published descriptions of pottery from the Middle Ouachita River region (Hodges and Hodges 1945; the Hodges catalogue from 1946 notes the purchase of Huddleston's collection of "approx. 350 pieces of pottery," so the 1000 pieces mentioned above seems to be inaccurate). The Hodges Collection, now owned by the Joint Educational Consortium, is important because most of the artifacts came from a cluster of sites in Clark and Hot Spring counties in west-central Arkansas. It is also historically significant for Caddo archaeology because Philip Phillips of Harvard University and Alex Krieger of University of Texas visited Thomas and Charlotte Hodges, Vere Huddleston, and Robert Proctor, and photographed pottery vessels in their collections. Some of these were used to illustrate types in the Handbook of Texas Archeology (Suhm and Jelks 1962; see also Early 1986; Newell and Krieger 1949:vii). Phillips' photographs of many of the Hodges Collection vessels in 1939, along with his note cards (on file at the Arkansas Archeological Survey's HSU Research Station), were instrumental in Early's (1978) identification of artifact provenience in the JEC Hodges Collection after 1977.

Based on notes now in the HSU Archives, Vere Huddleston dug graves at East Place (3CL21, see Figure 2) between April, 1939, and January, 1943. While a sketch map exists, his location descriptions are vague. Most of the graves were dug in and adjacent to a mound on the site's west side. Grave lot associations are clearer, and by matching dates, descriptions, and catalogue numbers, it has been possible to reconstruct grave lots for 18 graves dug by Huddleston (Table 1). In some cases, artifacts from a grave were divided between the excavators (typically Huddleston, Proctor, and Richardson), and therefore vessels from the same grave may be separated between the JEC Hodges and the HSU Museum collections.

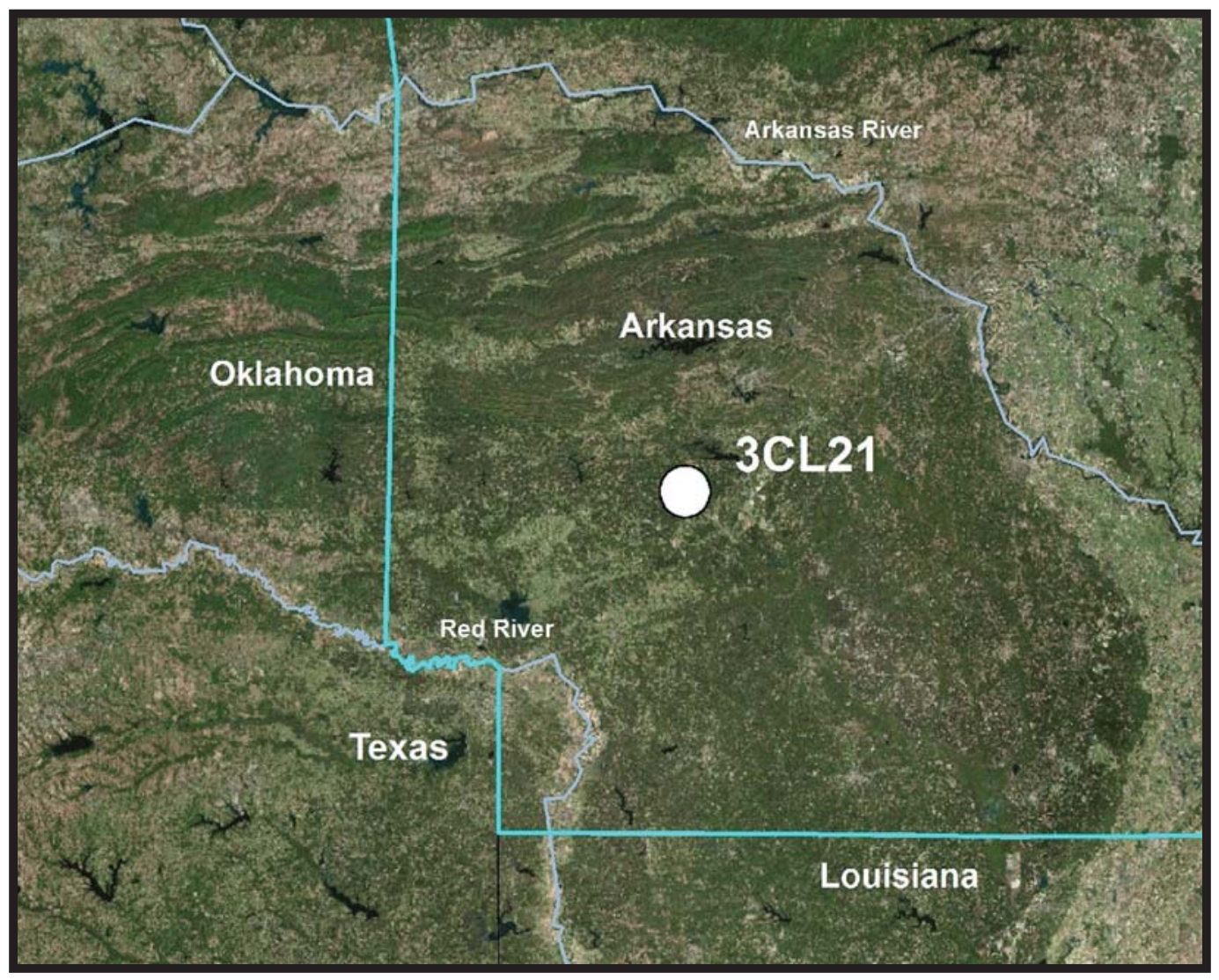

Figure 2. Approximate location of East Place (3CL21) in southwest Arkansas (map created by Katie Leslie, Arkansas Archeological Survey, 2014). 
Table 1. Reconstructed Grave Lots from Huddleston's East Site Excavations.

\begin{tabular}{|c|c|c|c|c|c|c|}
\hline \multirow[b]{2}{*}{ Grave Number } & \multicolumn{2}{|c|}{ Huddleston/Hodges } & \multirow[b]{2}{*}{ Huddleston Description } & \multirow{2}{*}{\multicolumn{2}{|c|}{$\begin{array}{l}\text { 3CL0021: } \\
\text { Prov/Item }\end{array}$}} & \multirow{2}{*}{$\begin{array}{l}\text { AASurvey Documentation } \\
\text { Vessel Form }\end{array}$} \\
\hline & Cat. \# & $\begin{array}{r}\text { Cat. } \\
\#\end{array}$ & & & & \\
\hline \multicolumn{7}{|l|}{ First set: } \\
\hline Grave 1 and/or 2 & 197 & 1374 & & 1 & 48 & bowl, carinated \\
\hline $4 / 29 / 1939$ & 198 & 1375 & & 1 & 49 & bowl, carinated \\
\hline \multirow[t]{2}{*}{ [late Social Hill to Deceiper phase] } & 199 & 1376 & engraved red ware carinated bowl (sketched) & 1 & 36 & bowl, carinated, tall rim \\
\hline & 200 & 1368 & whole piece (sketch - bottle) & 1 & 12 & bottle \\
\hline Grave 3,20 " deep on original soil & 201 & 1380 & 1 of 3 broken pieces (sketch - jar) $[201=1380 ?]$ & 1 & 41 & jar, tall rim \\
\hline $4 / 29 / 1939-5 / 5 / 1939$ & 202 & 1373 & 1 of 3 broken pieces, cazuela / hanging bowl with scalloped rim & 1 & 34 & bowl \\
\hline \multirow[t]{6}{*}{ [late Social Hill to Deceiper phase] } & 203 & & 1 of 3 broken pieces, cazuela & & & \\
\hline & 204 & 1379 & cazuela & 1 & 32 & bowl, carinated \\
\hline & 205 & & jar & & & \\
\hline & 206 & & jar & & & \\
\hline & 207 & 1371 & bottle, perfect (sketch) & 1 & 13 & bottle, pedestalled \\
\hline & 208 & 1372 & human effigy bottle, perfect (sketch) & 1 & 50 & bottle, effigy, pedestalled \\
\hline Grave 4,6 ' east of other graves & 222 & & badly broken, part of deep bowl & & & \\
\hline $5 / 27 / 1939$ & 223 & & badly broken, jar & & & \\
\hline \multirow[t]{7}{*}{ [late Mid-Ouachita to Social Hill phase] } & 224 & 1412 & badly broken, large jar 1412 [224=1412?] & 1 & 42 & jar, tall rim \\
\hline & 225 & & small vase & & & \\
\hline & 226 & 1388 & deep bowl, small, notched rim [226 $=1388 ?]$ & 1 & 35 & bowl, simple \\
\hline & 227 & 1384 & deep bowl, large, notched rim [227 = 1384?] & 1 & 39 & bowl, simple \\
\hline & 228 & & plain water bottle, neck broken & & & \\
\hline & 229 & 1387 & badly broken cazuela (sketch, 228 almost ident.) [229 = 1387?] & 1 & 38 & bowl, carinated \\
\hline & 230 & & badly broken cazuela & & & \\
\hline Grave 4 A, 5/27/1939 & 231 & & Ritchie ruined one with shovel, Huddleston recovered it & & & \\
\hline \multicolumn{7}{|l|}{ South of other graves: } \\
\hline Grave 5 , no trace of bone, 24 " deep, 2 graves? & 232 & & pipe, broken (sketch) & & & \\
\hline \multirow[t]{4}{*}{ 6/7/1939 } & 233 & & bottle (sketch) [Crockett Curvilinear-Incised] & & & \\
\hline & 234 & & pot (sketch) [cogged rim bowl?] & & & \\
\hline & & & pot, to Whaley & & & \\
\hline & & & bottle, Glendora ware, to Ritchie & & & \\
\hline \multicolumn{7}{|l|}{ West side of the mound/next to the slough: } \\
\hline Grave 6,12 " deep & 235 & & bottle, crushed (sketch) [Keno Trailed] & & & \\
\hline \multirow[t]{7}{*}{$6 / 10 / 1939$} & 236 & & cazuela, cone-shaped, partial (sketch) & & & \\
\hline & 237 & & vessel, partial & & & \\
\hline & 238 to 240 & & 3 bone awls & & & \\
\hline & 241 & & bottle, Glendora ware, crushed (sketch) & & & \\
\hline & 242 & & vessel, whole & & & \\
\hline & 243 & & skull & & & \\
\hline & & & broken bowl, to Whaley & & & \\
\hline \multicolumn{7}{|l|}{ Base of Mound C: } \\
\hline Grave 7, shallow & 1 & & & & & \\
\hline $8 / 5 / 1939$ & 2 & & & & & \\
\hline \multirow[t]{3}{*}{ [late Social Hill to Deceiper phase] } & $244-4$ & 2098 & cone shaped cazuela (sketched) & 1 & 33 & bowl, carinated \\
\hline & $245-3$ & 2097 & water bottle, Glendora ware & 1 & 16 & bottle, pedestalled \\
\hline & 245 & & small bowl covered with 6 rim projections (sketched) & & & \\
\hline
\end{tabular}




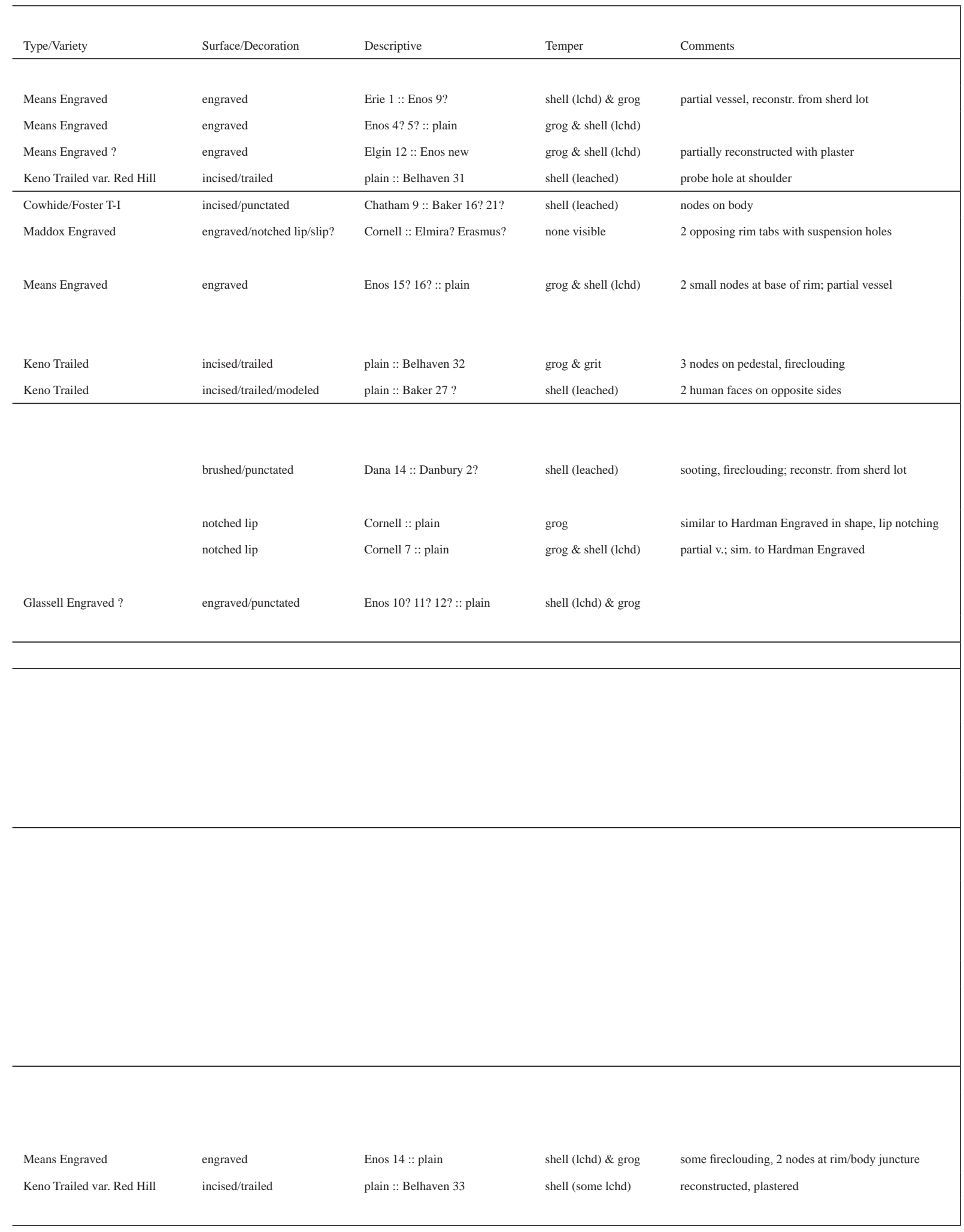


Table 1. Reconstructed Grave Lots from Huddleston's East Site Excavations (cont.).

\begin{tabular}{|c|c|c|c|c|c|c|}
\hline Grave $\mathrm{X}$, no bone, 4 crushed pots & & 2490 & incised red slip bowl (sketched) & 1 & 9 & bowl, simple \\
\hline $5 / 9 / 1941$ & & 2491 & & 1 & 1 & bowl, simple \\
\hline \multirow[t]{2}{*}{ [East phase] } & & 2492 & incised red slip bowl (sketched) [sketch does not match 2492] & 1 & 5 & beaker \\
\hline & & 2493 & incised/punctated jar (sketched) & 1 & 28 & jar, short rim \\
\hline \multicolumn{7}{|l|}{ On ramp or saddle between mounds: } \\
\hline Grave $\mathrm{X}$ or $\mathrm{Y}$, tooth crowns, 3 pots, 40 " deep & 1 & 2511 & crushed pot & & & \\
\hline $12 / 6 / 1941$ & 2 & 2512 & crushed pot & 1 & 23 & bottle \\
\hline [Mid-Ouachita phase] & 3 & 2513 & crushed pot & 1 & 47 & bottle \\
\hline \multicolumn{7}{|l|}{ In small burial mound just $N$ of the 4 large mounds: } \\
\hline found by Dr. Ritchie, May 1942 & & 2641 & wood duck head, carved wood, semi-charcoal state, pigment & 1 & 11 & effigy adorno, carved wood \\
\hline \multicolumn{7}{|l|}{ No provenience noted: } \\
\hline September, 1942 [East phase] & & & Labeled "East Sept. 42" on base & 1 & 10 & jar, short rim \\
\hline \multicolumn{7}{|l|}{ No location indicated: } \\
\hline Grave XX, 18 ” deep, trace bone, 4 pots, red ochre & & 2642 & perfect / incised red ware (sketched) & 1 & 22 & jar, tall rim \\
\hline $9 / 19 / 1942$ & & 2643 & struck with shovel and needs repairing / incised jar (sketched) & 1 & 21 & jar, short rim \\
\hline \multirow[t]{2}{*}{ [East to Mid-Ouachita phase] } & & & Mr. Charlie took bottle, plain, with small tall neck & & & \\
\hline & & & Mr. Proctor took small slip bowl similar to Hudd 1305 & & & \\
\hline \multicolumn{7}{|l|}{ In mound: } \\
\hline Grave A, 6' deep, 1 crushed bottle, skull in ash & & & crushed bottle & & & \\
\hline $11 / 14 / 1942$ & & 2693 & skull (from Grave A?) & & & \\
\hline Grave A' (next to A, depth 6' $6^{\prime \prime}$ ) 15 pots, no bone & & 2688 & plain bottle of red slipware (sketched) & 1 & 30 & bottle \\
\hline $11 / 14 / 1942$ & & 2689 & incised jar (sketched) & 1 & 4 & jar, tall rim \\
\hline \multirow[t]{7}{*}{ [East phase] } & & 2690 & engraved red ware (sketched) & 1 & 19 & beaker \\
\hline & & 2691 & & 1 & 46 & jar, tall rim \\
\hline & & 2692 & bottle, engraved red ware (sketch) & 1 & 31 & bottle \\
\hline & & & Proctor took large beautiful bowl about a gallon capacity & & & \\
\hline & & & (another 9 vessels originally in grave, no info) & & & \\
\hline & & & long stemmed platform pipe & & & \\
\hline & & & celt & & & \\
\hline \multicolumn{7}{|l|}{ No location indicated: } \\
\hline Grave B, 18 " deep, 8 pieces of pottery ( 3 effigies) & & 2694 & effigy pot / incised red slip effigy bowl (sketched) & 1 & 14 & effigy bowl \\
\hline $11 / 21 / 1942$ & & 2695 & engraved beaker (sketched) & 1 & 3 & beaker \\
\hline \multirow[t]{8}{*}{ [East phase] } & & 2696 & bottle, engraved (sketched) & 1 & 2 & bottle \\
\hline & & 2697 & celt & 1 & 45 & celt \\
\hline & & $\begin{array}{r}2698 \text { to } \\
2707\end{array}$ & 10 small points (10 to Hudd, 10 to Mr C, 9 to Mr Proctor) & & & \\
\hline & & & pot, $\mathrm{MrC}$ & & & \\
\hline & & & effigy pot, $\mathrm{MrC}$ & & & \\
\hline & & & effigy pot, Mr P & & & \\
\hline & & & pot, Mr P & & & \\
\hline & & & pipe, $\mathrm{Mr}$ Proctor & & & \\
\hline
\end{tabular}




\begin{tabular}{|c|c|c|c|c|}
\hline East Incised & red slipped/incised & Barrington $10::$ plain & grit & rim tabs, abrasion on base \\
\hline \multirow[t]{3}{*}{ East Incised } & red slipped/incised & Barrington 9 :: plain & grog \& grit & 2 incised rim tabs \\
\hline & plain & :: plain & grog \& grit & badly broken, missing rim \\
\hline & incised/punctated & Caldwell 3 ? :: Claflin & grog & reconstructed; related to Sinner Linear-Punctated? \\
\hline \multirow[t]{2}{*}{ Adair Engraved } & engraved/appliqued & Eagle 3 :: Eric 1 & grog & \\
\hline & engraved & plain :: Elmira 60 ? Elmhurst 9? & grog & sherd lot, not reconstructed \\
\hline Karnack Brushed-Incised? & incised & plain :: Antioch 3 & grog \& grit & fireclouds \\
\hline Pease Brushed-Incised? & incised/applique & Butler 1 :: Alma 3? & grog & 7 nodes around body, sooting \\
\hline sim. to Military Road Inc. & brushed/incised/punctated & Dana 4 :: Altus 4 & grog & broken rim; related to Sinner Linear-Punctated? \\
\hline
\end{tabular}

\begin{tabular}{lllll}
\hline Smithport Plain & red slipped & plain :: plain & grog \& claygrit & fireclouds \\
Pease Brushed-Incised? & incised/punctated & Caldwell $15::$ Antioch 14 & grog \& grit & or Dunkin Incised? \\
East Incised & red slipped/incised & Barrington $7::$ plain & grog \& claygrit & suspension holes \\
& punctated/brushed & Andes? :: Danbury 1 & grog & reconstr. from sherd lot \\
Hickory Fine Engraved & engraved & plain :: Erie 13 & grog \& bone & fire clouds
\end{tabular}

$\begin{array}{lllll} & & & \\ \text { East Incised } & \text { red slipped/incised/effigy } & \text { Bates } 15 \text { or Barrington 5::plain } & \text { grog } & \text { animal head \& tab on rim, reconstr. with plaster } \\ \text { East Incised? } & \text { incised } & \text { Bates } 16:: \text { plain } & \text { grog \& grit } & 2 \text { suspension holes } \\ \text { Spiro Engraved? } & \text { red slipped/engraved } & \text { plain :: Evangel } 1 & \text { grog \& grit } & 3 \text { circular panels of curvilinear engraving/excising }\end{array}$


Table 1. Reconstructed Grave Lots from Huddleston's East Site Excavations (cont.).

\begin{tabular}{|c|c|c|c|c|c|}
\hline Grave C, 5 ' deep, 4 pots & 2708 & bottle & 1 & 25 & bottle \\
\hline $12 / 12 / 1942$ & 2709 & pipe stem, bowl deteriorated & 1 & 15 & long stem pipe \\
\hline \multirow[t]{5}{*}{ [East phase] } & 2710 & perforated jar/beaker type jar, incised red ware (sketched) & 1 & 18 & beaker \\
\hline & $\begin{array}{r}2711 \text { to } \\
2724\end{array}$ & small point (14 of 19 to Hudd) & & & \\
\hline & & bottle to Proctor & & & \\
\hline & & perforated jar/beaker jar to Proctor & & & \\
\hline & & celt, Proctor & & & \\
\hline \multicolumn{6}{|l|}{ Mound, west of center of mound: } \\
\hline Grave $\mathrm{D}, 5^{\prime}$ deep, no trace of bone & 2725 & bottle, crushed, Coles Creek ware, plain-red slip (cat card/sketch) & 1 & 7 & bottle \\
\hline $12 / 13 / 1942$ & 2726 & vase, crushed/ incised redware (sketched) & 1 & 17 & beaker \\
\hline \multirow[t]{2}{*}{ [East phase] } & 2727 & copper covered artifact & & & \\
\hline & & pot, Proctor (urn-shaped pot in good condition?) & & & \\
\hline \multicolumn{6}{|l|}{ Mound: grave on top of the mound: } \\
\hline Grave $\mathrm{E}$, in hard clay, only trace of bone & 2729 & pot, crushed / incised jar (sketched) & 1 & 20 & jar, tall rim \\
\hline $12 / 18 / 1942$ & 2730 & large crystal & 1 & 27 & quartz crystal \\
\hline \multirow[t]{5}{*}{ [East phase] } & 2731 & arrow & & & \\
\hline & 2732 & copper covered object & & & \\
\hline & & good pot to Proctor & & & \\
\hline & & pipe to Proctor & & & \\
\hline & & large crystal to Proctor & & & \\
\hline \multicolumn{6}{|l|}{ No location indicated: } \\
\hline Grave $F, 6$ ' deep & 2742 & bottle, in good shape (sketched) & 1 & 24 & bottle \\
\hline $1 / 1 / 1943$ & 2743 & pot, crushed & & & \\
\hline \multirow[t]{10}{*}{ [East phase] } & 2744 & pot, crushed / incised jar (sketched) & 1 & 29 & jar, tall rim \\
\hline & 2745 & pot, crushed / engraved jar (sketched) & 1 & 8 & jar, tall rim \\
\hline & 2746 & pot, crushed & 1 & 44 & bowl \\
\hline & 2747 & pot, crushed & 1 & 43 & beaker \\
\hline & 2748 & crystal & 1 & 26 & quartz crystal \\
\hline & $\begin{array}{r}2749 \text { to } \\
2755\end{array}$ & small point ( 7 to Hudd, 7 to Proctor) & & & \\
\hline & & bottle, in good shape, to Proctor & & & \\
\hline & & pot, crushed, to Proctor & & & \\
\hline & & celt to Proctor & & & \\
\hline & & crystal to Proctor & & & \\
\hline \multicolumn{6}{|l|}{ Mound, on top of mound: } \\
\hline Grave G, 4' deep & 2756 & vase incised with punctates from rim to base (sketched) & 1 & 37 & jar, short rim \\
\hline $1 / 16 / 1943$ & 2757 & vase with inward sloping sides, rim perforations (sketched) & 1 & 6 & beaker \\
\hline \multirow[t]{2}{*}{ [East to Mid-Ouachita phase] } & $\begin{array}{r}2758 \text { to } \\
2765\end{array}$ & 8 small points, Hudd & & & \\
\hline & & water bottle, to Proctor, beautiful red ware bottle & & & \\
\hline \multicolumn{6}{|l|}{ No provenience noted: } \\
\hline ? date [East phase?] & & No number, no info & 1 & 40 & jar, short rim \\
\hline
\end{tabular}




\begin{tabular}{|c|c|c|c|c|}
\hline sim. to Hickory Fine Engr. & incised (dry paste) & Bates $9::$ plain & grog & pedestal base \\
\hline East Incised & incised & Bates $3::$ plain & grog & 2 suspension holes \\
\hline
\end{tabular}

\begin{tabular}{lllll}
\hline & & & \\
Smithport Plain ? & red slipped $?$ & plain :: plain & grog \& grit & heavily mended bottle \\
East Incised & incised & Barrington $1::$ plain & grog & suspension holes (2)
\end{tabular}

Pease Brushed-Incised $\quad$ incised/punctated $\quad$ Andes 10?:: Alma $3 \quad$ grog reconstructed

\begin{tabular}{|c|c|c|c|c|}
\hline Smithport Plain & plain & plain :: plain & grog \& claygrit & fireclouds, black residue on body \\
\hline Pease Brushed-Incised & incised & Beloit 1 :: Alpha 2 & grog & residue on base/ext. \\
\hline Pease or Karnack B-I & incised/punctated & Case 8 :: Claflin 8 & grog & heavily mended, 2 opposable rim tabs \\
\hline East Incised & incised & Bates 3 or Barrington $1::$ plain & grog & reconstr. from sherd lot \\
\hline East Incised & incised/red slipped & Bates $17 ?::$ plain & grog & partial vessel, suspension hole \\
\hline Military Road Incised & incised/punctated & Beloit $2::$ Clinton 12, Bard 2? & grog \& claygrit & fireclouds, slightly castelated rim; pigment assoc.? \\
\hline East Incised? & engraved & Eckerd $2::$ plain & grog \& grit & 2 suspension holes \\
\hline sim. to Smithport Plain ? & red color from ochre? & plain :: plain & grog \& grit (mica) & human bone fragments in jar, no info \\
\hline
\end{tabular}


Phillips photographed eight of Huddleston's vessels from East Place. Krieger examined and photographed East Place vessels from both the Proctor and the Huddleston collections, the latter owned by the Hodgeses by that point, and illustrated several plates of East vessels in the George C. Davis monograph (Newell and Krieger 1949:vii, Fig.63-65). The description of East in the Davis monograph was brief since "[d] etails on the mound and graves are lacking" (Newell and Krieger 1949:210). Clarence Webb included East pottery in his description of the type Dunkin Incised and the Bossier focus, crediting Dr. and Mrs. T. L. Hodges and Alex Kreiger (Webb 1948:106). Again, the description of the site is brief. "Pottery from the East Mound, a Haley focus site on Antoine River in southern Arkansas, includes a number of vessels which have shapes similar to Pease vessels and decoration consisting of incised fields, often herringbone, separated by incisions, nodes or lines of punctates," (Webb 1948:113). Huddleston and his contemporaries referred to Caddo pottery and earlier pre-Caddo wares similar to Marksville or Coles Creek complexes; Webb and the Hodgeses used the Midwest Taxonomic System and referred to Haley and Mid-Ouachita foci (Girard et al. 2014).

By the late $20^{\text {th }}$ century, archaeologists were defining phases that had geographic as well as temporal boundaries, reinforced by radiocarbon dates. In an unpublished paper on East Place ceramics based on vessels in the HSU Museum from the Horton, Proctor, Richardson, and Whaley collections, Cynthia Weber (1972) emphasized that there were multiple components at the site, not just the Early to Middle Caddo period material illustrated in earlier publications. Despite the lack of published information, East became the type site for the East phase, initially described by Weber (1972) and later defined by Early (ed., 1993; Early 2002a). A sequence of phases -- East, Mid-Ouachita, Social Hill, and Deceiper -- have been defined for the Middle Ouachita River region between A.D. 1100-1700 (Early 2002a, b, c, d; Early, ed., 1993).

In addition to the East Place vessels in the HSU Museum collections (Early 2002a; Weber 1972), there is a set of vessels excavated from East by Odis and Nell Sullivan in the 1950s to 1970s, recently donated to the Arkansas Archeological Survey (Morrow et al. 2014). Ann Early created a topographic map of the site in 1980, and she and Daniel Wolfman collected two samples for archaeomagnetic dating. The dates, EA 89-90, from baked clay structure floors within two mounds at East, returned dates of $1270 \pm 20$ and $1400 \pm 25$ (Wolfman 1982). This helped establish that the East phase was a Middle Caddo period manifestation. The site was used into the Late Caddo period as well. A future project will bring together available information from these different sources on East, and provide a clearer discussion of the history of site use.

Here, we present Vere Huddleston's manuscript describing his East Place excavations. The typed manuscript and several pages of an earlier handwritten version are in the HSU Archives (Hodges Collection, 41/04D 43-50, 41/04E 1-2). The manuscript, written about 1945, is accompanied with several pages of artifact sketches (Figures 3, 4, 5) that include Huddleston's vessels as well as those of Richardson, Proctor, Ritchie, Whaley, and Horton. For this article, we have edited lightly (corrected spelling, changed endnotes to in-text citations, and added several headings), deleted locational information to protect archaeological sites from further disturbance, and made several editors' notations. Our detailed discussion and documentation of Huddleston's East vessels follows the manuscript. 


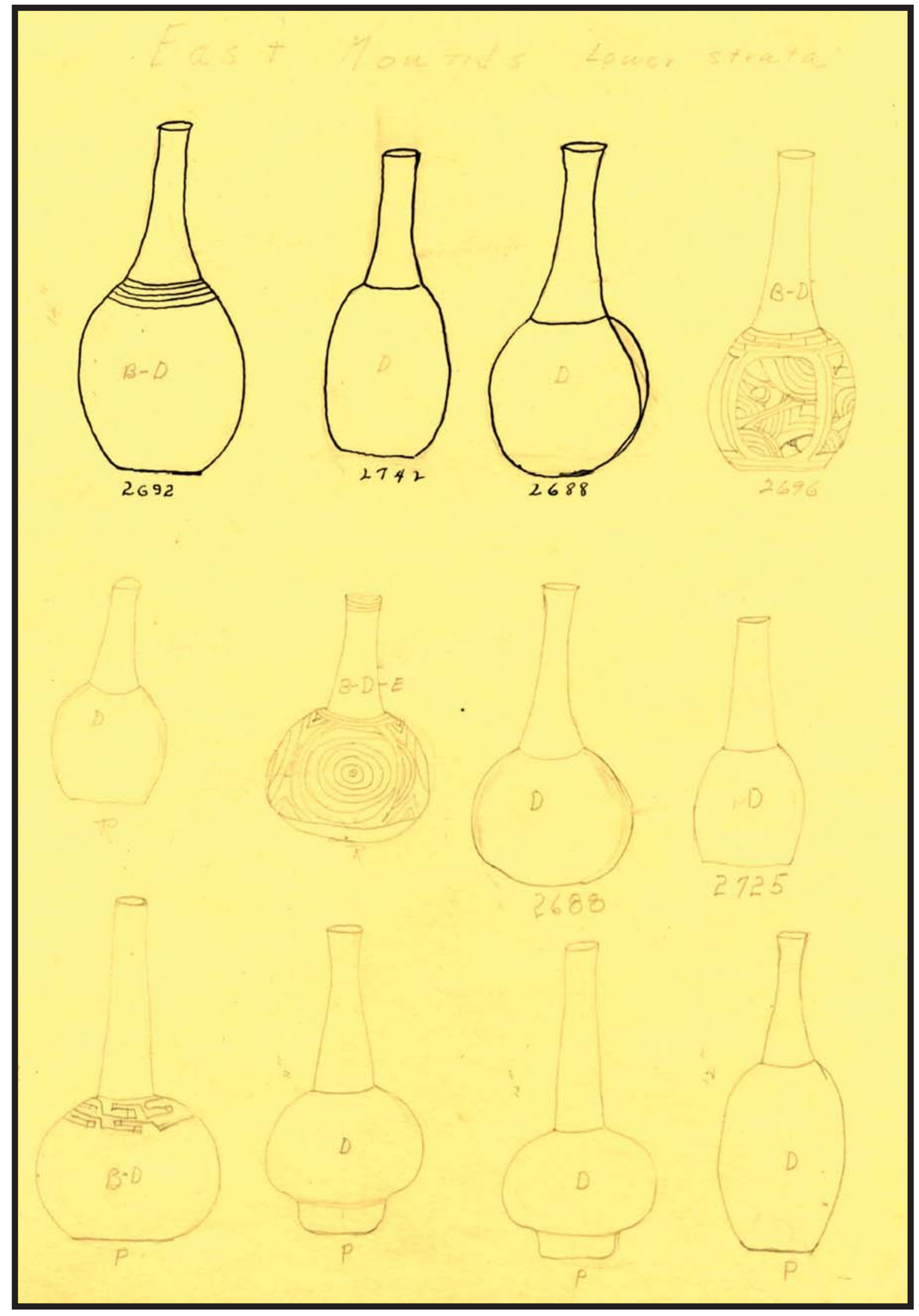

Figure 3. Huddleston's sketches of bottles from East Place (HSU Archives, Hodges Collection, 41/04D-62). 


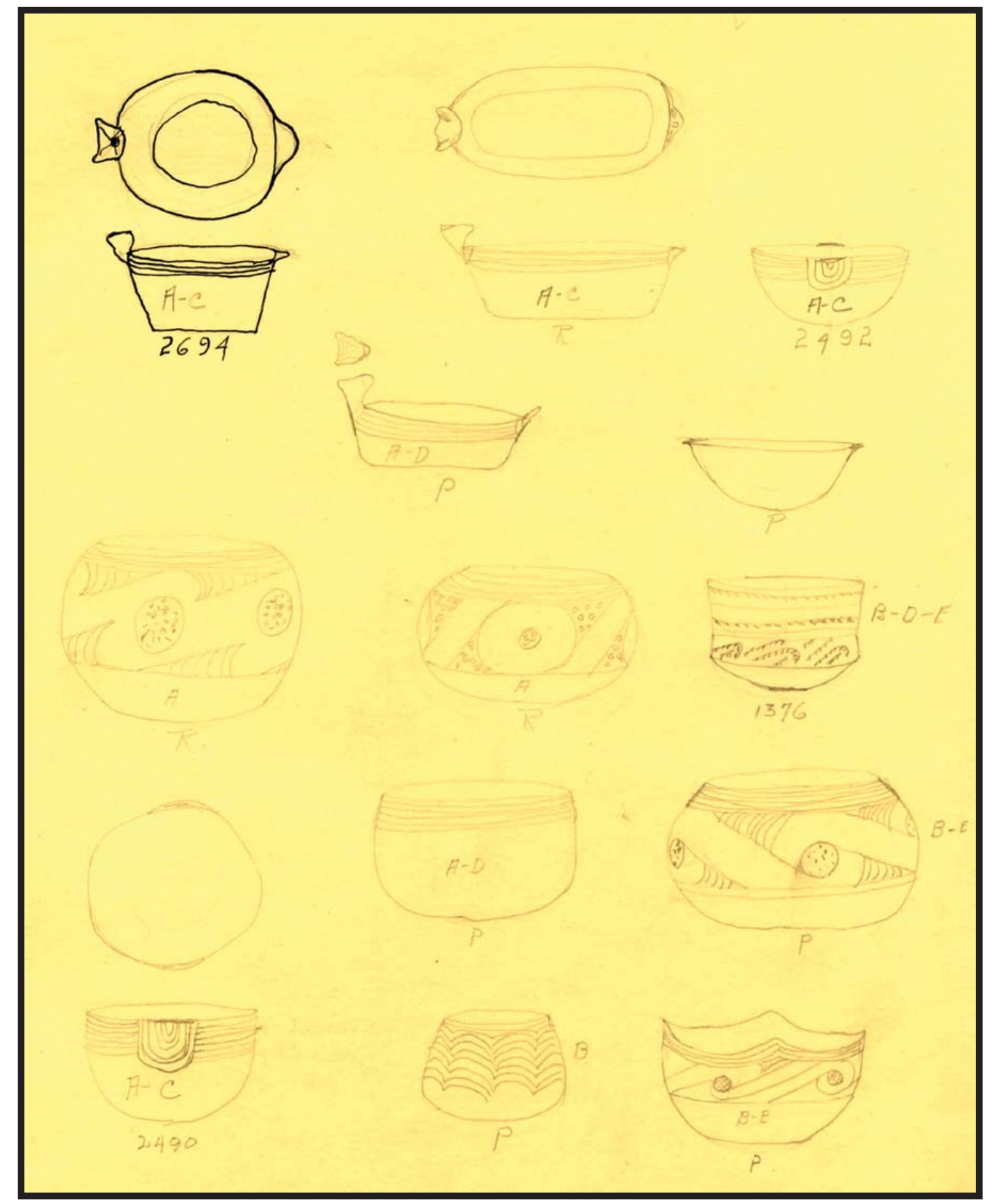

Figure 4. Huddleston's sketches of bowls from East Place (HSU Archives, Hodges Collection, 41/04D-40). 


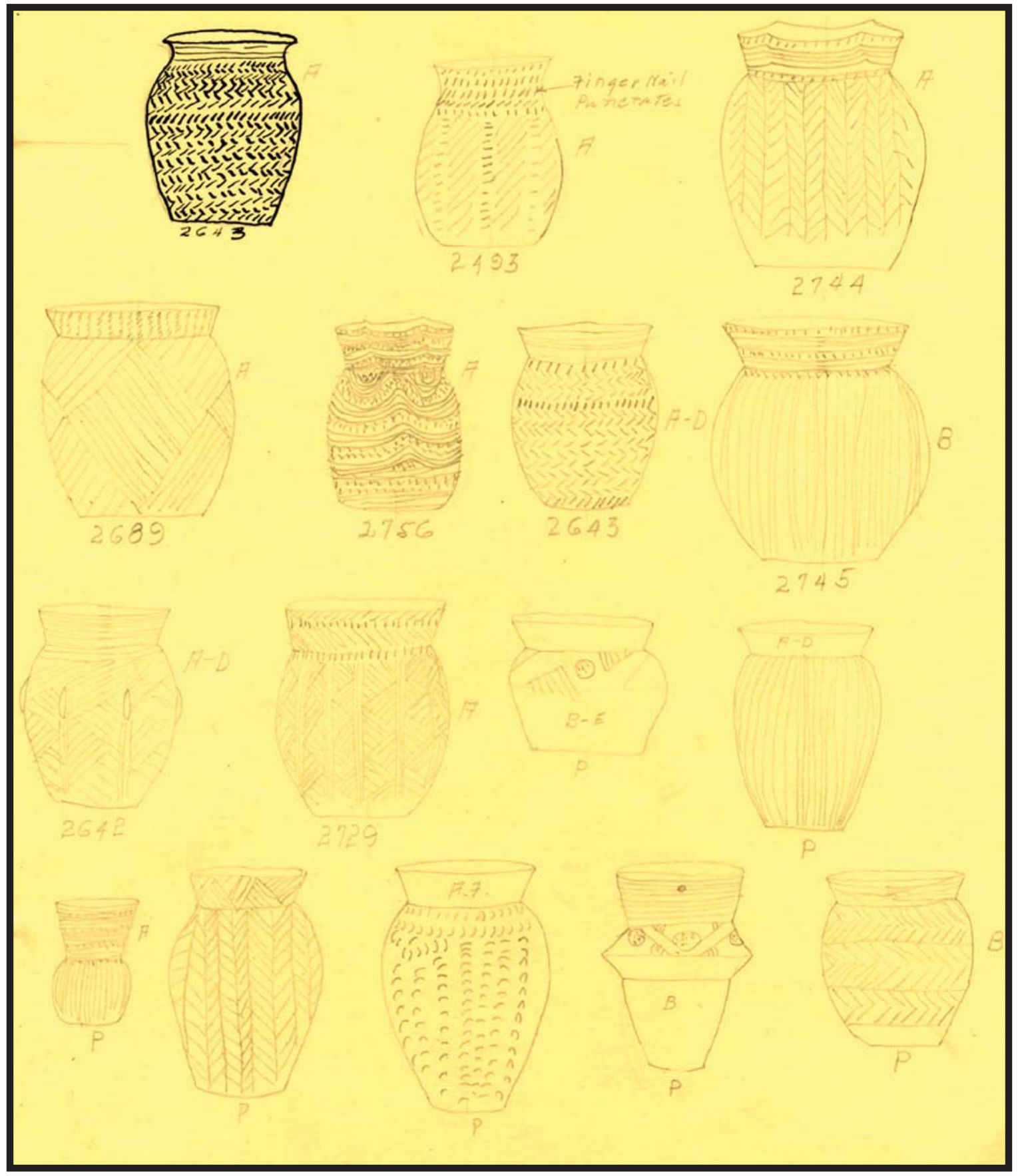

Figure 5. Huddleston's sketches of jars from East Place (HSU Archives, Hodges Collection, 41/04D-61). 


\section{Vere Huddleston's “Ancient Village Sites on Antoine River in Clark County, Arkansas"}

There is in the western part of Clark County on the W. B. East farm on the Antoine

River, a mound site which from all indications is very early Caddo. The name Pre-Columbian Caddo has been given to the culture the pottery indicates by C. H. Webb of Shreveport, Louisiana (personal conference April 10, 1945).

The site is part of a long series of mounds and village sites extending from above the present village of Antoine, on the Antoine River, to a point about five miles down the Antoine to its confluence with the Little Missouri, and some two miles down the Little Missouri. Most of the mounds are on the east or Clark County side of the river. One large mound is on Buren Hardin's farm .... [Eds.: locations deleted in this paragraph and next; descriptions indicate archaeological sites 3NE68, 3CL60, and 3CL29]. Sherds and stone artifacts picked up on this site indicate a possible Marksville culture.

About ... miles above the East site is considerable evidence of a camp site area and a large conical mound approximately twenty feet high. About ... miles below is the Kirkham site excavated by Lemley and Dickenson in 1932 (Dickinson and Lemley 1939).

Nowhere in the Ouachita Valley has the writer seen a mound site area similar to the East site. It is located ... on an old bank of the Antoine River .... The site covers between twenty and thirty acres and consists of fifteen mounds that are still quite noticeable and possible remnants of others that the river and the plow have long since obliterated. All but four are from a few inches to three or four feet in height. These four are much larger than the others and are arranged in a semicircle and connected by lower saddles or ramps. The tallest is about fifteen feet high, and is near the center of the semicircle.

The topography of the site and its size makes it likely to conclude that this is the Quipana mentioned in the travels of De Soto as narrated by the Gentleman of Elvas (Swanton 1939:230, 255). [Eds.: While the Swanton Commission placed Quipana on the Antoine or Little Missouri River, modern reconstructions of the De Soto route places both Tula and Quipana further north in the Ouachita Mountains (Early 1993). The Spanish may have passed through the Little Missouri region on their way west after visiting Chaguate in the Middle Ouachita River region, however (Girard et al. 2014; Schambach 1993).]

The first excavation known to the author was made in 1933 by Lemley and Dickinson (personal conference with S. D. Dickinson, 1943). This was merely a superficial visit and only one excavation was made in one of the connecting ramps. Nothing was found.

On April 29, 1939, the author in company with Dr. Otis Whaley and Dr. William Ritchie, both of the faculty of Henderson State Teachers College, visited the site and found on the south slope of a mound a burial area which yielded several graves ranging in depth from a few inches to thirty inches. There were in all about twenty graves in this group, some so close to the surface that the plow had wrecked the tops of the pottery. All the pottery, the stone and bone artifacts, and the two pipes recovered were of the typical Caddo ware so common to the Ouachita Valley area. Skeletal material was either completely deteriorated or so soft as to be beyond recovery with one exception; this was a very shallow grave at some 
distance down the west slope of the mound and isolated from the other graves. The skull and some of the other bones were well preserved. With this burial were three Glendora bottles arranged around the head, two cone-shaped bowls near the right hand, and a broken food jar between the outstretched legs. Near the right elbow were three beautifully worked and polished bone awls. All the pots were crushed. [Eds.: Huddleston notes 7 graves (Table 1: Graves 1-7) that he dug in 1939; this description refers to his Grave 6, but neither the human remains nor the objects from this grave have been identified in the JEC Hodges Collection.]

All these graves were in black kitchen midden and had been buried in all directions with the majority facing east. There was a larger percentage of Glendora bottles than in any other typical Caddo site known to the author. Of some possible significance is the fact that no seed jars were found. Of the two pipes found one was of elbow pattern and the other a modified platform type, similar to the long stemmed pipes found later. The stem was four inches long and the projection of the stem beyond the bowl was pointed. Both types are common in typical Caddo burials. In all some eighty-five pieces of pottery were taken out but about three-fourths were badly crushed or wrecked by the plow. [Eds.: About 37 vessels were mentioned in Huddleston's notes from the 1939 excavations (Table 1), 15 of which have been identified in the JEC Hodges Collection. His figure of 85 pieces of pottery presumably also includes pots from graves dug by Whaley and Ritchie.]

About a year after excavation of the above described area we by accident discovered on top of the same mound, a grave thirty inches deep that yielded a type of pottery which we recognized immediately as something distinctly different from the typical Caddo pottery. [Eds.: This is Huddleston's Grave X, excavated 5/9/1941.]

The area in which the burials were found yielding this type of pottery covered roughly a spot about thirty feet square. The burials ranged in depth from two and one-half to seven feet. All were the same in that it was necessary to excavate through hard packed clay to reach them, and most of them were on a level of between six and seven feet deep.

There was only an occasional sherd or piece of charred wood to indicate the soil had ever been disturbed. All the burials were intrusions in a previously undisturbed clay seems to have been used [Eds.: Huddleston may have meant 'that seems to have been unused.'].

Occasionally a layer of ashes mixed with clay would be encountered. In all the deep graves there was a layer of silt deposit two inches thick and approximately thirty inches above the grave floor level. As it was uniform in thickness and about the same depth in all the burials it seems to indicate a break period in the construction and use of the mound as a burial site. In all, four burials were found above this silt deposit which contained the same type pottery. A total of twenty-four graves were excavated. In addition to the three people mentioned in the first of this paper as assisting in the excavation the following people also took part: Mr. R.T. Proctor, Mr. Charlie Richardson, Dr. P.G. Horton and Dr. Erwin. The twentyfour graves yielded on hundred and twenty pieces of pottery, six celts or fist hatchets, five crystals, five quivers of arrows containing a total of over one hundred points, one pair slate ear spools, one wood effigy wood duck head, five long stem pipes and one platform pipe, one piece of galena and several traces of copper artifacts. [Eds.: Huddleston's notes describe 
about 11 graves dug by him between May 1941 and January 1943, with about 54 pottery vessels (Table 1); 30 of these vessels, along with 1 celt, 1 pipe, 2 quartz crystals, and the wooden duck head adorno (Figure 6) have been identified in the JEC Hodges Collection.] There was no skeletal material found in any of the graves except one which showed evidence of cremation, only the skull remained. In most of the graves not a trace of bone remained. Possible skeletal positions could be determined only by the position of artifacts.

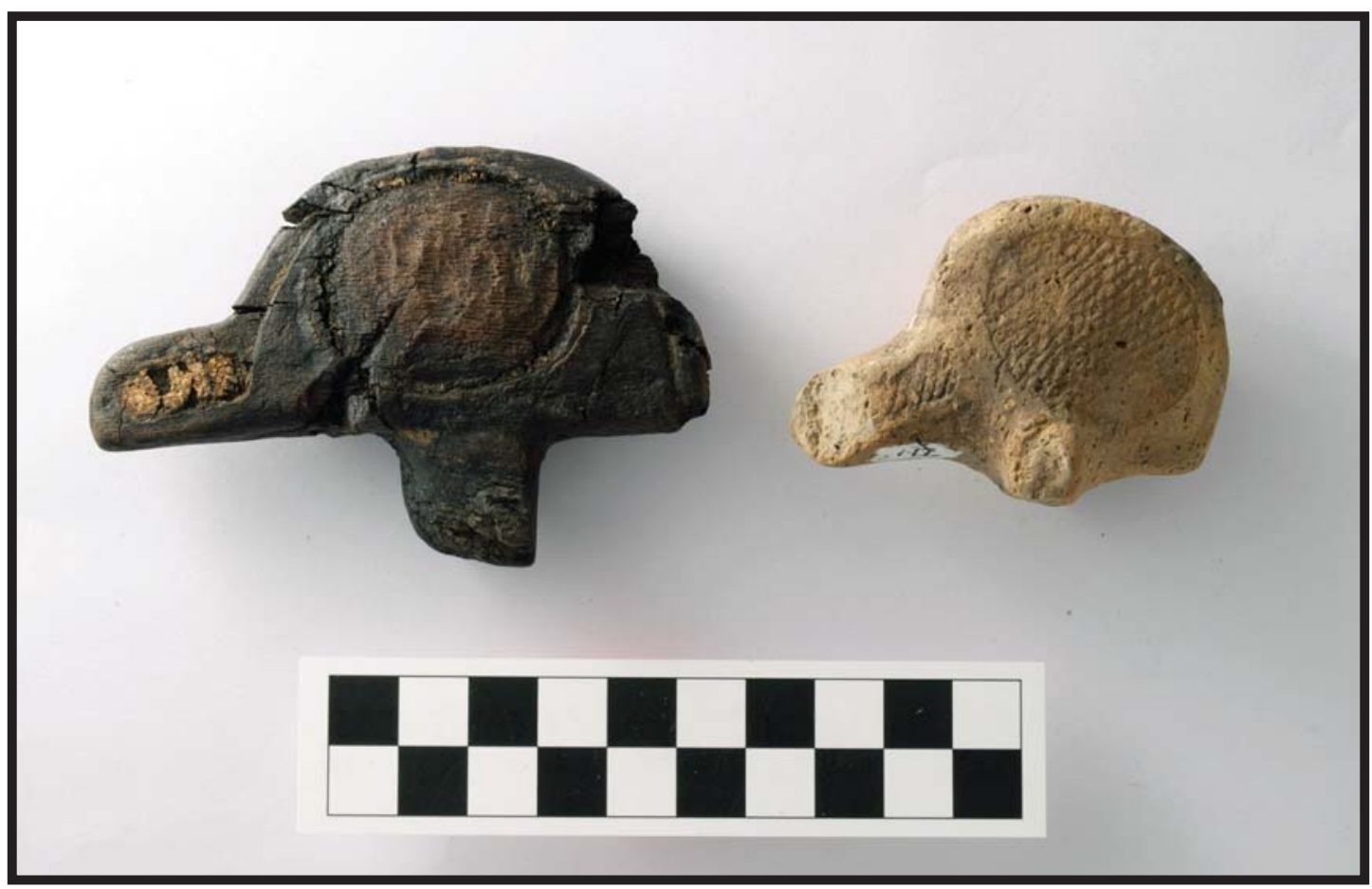

Figure 6. Duck head effigy adornos, JEC Hodges Collection: left, carved wooden artifact from East Place, 77-1/1-11; right, ceramic effigy, no provenience, 77-1/X

(Arkansas Archeological Survey digital photograph AASHSUD_N8995).

Two burials contained portions of charred remains of what appeared to have been cane mats that had been placed over the body and burial furnishings. There are six other sites known in the Ouachita Valley where similar artifacts and burial conditions have been found - the Crenshaw site (Dickinson 1936), Haley Place (Moore 1912:527-564), Ozan (Harrington 1920), Gahagan mound site (Webb and Dodd 1939), and two other sites in Clark County from which similar pottery has been taken by the author. [Eds.: Crenshaw (3MI6), Haley (3MI1), and Gahagan (16RR1) are in the Red River valley in Arkansas and Louisiana while the sites near Ozan, including Ozan 1, 3HE37, and Washington, 3HE35, are between the Little River and Little Missouri River drainages in Arkansas. The Clark County sites he refers to may have been 3CL40 and 3CL84, based on several East Incised, Sinner Linear Punctated, and Smithport Plain vessels that have been documented in the JEC Hodges Collection.]

Pottery. The pottery is characterized by the following: a predominance of red ware or red slip ware; absence of seed jars; beaker type vessels with pierced rims; tall necked bottles which gradually enlarge from the top to the base; bottles with bases; no shell tempered ware; a good percentage of flat bottom pieces; few effigies (only three in all); and most of the decoration of rather simple lines or punctates. The decoration consisted of 
both incised and engraved lines, punctates, raised or pinched designs, fingernail punctates, scalloped rims, and what appears to be an attempt to imitate stamped ware in at least two pieces. There were several semi-globular bowls similar to those described by Harrington (1920) from the Ozan site.

Two of these bowls were unique in that both engraving and incised lines were used in executing the motif. In both, the potter had incised the characteristic four to six lines around the rim on a slightly thickened incurving portion of the vessel, this portion being just as wide as the space used for the lines. After this incising the vessel had been given a red slip coat and engraved with circles and semi-interlocking scrolls, the motif covering almost the entire outside of the vessel. [Eds.: Based on the accompanying sketches, at least one of these is a Crockett Curvilinear Incised bowl collected by Ritchie.]

Of the three effigies found all were most alike and in the same grave. They were all small bowls, the largest being five inches in diameter, the other two were boat shaped. Each consisted of the head of what may have been meant for a fox attached to the rim and looking into the bowl. On the opposite side of the rim is a small projection resembling a tail. The decorative motif in each was the same, four to six incised lines on a slightly thickened portion of the rim. All had also been treated with a red slip coat. [Eds.: These vessels were described in Huddleston's notes as coming from his Grave B, with one going to Mr. Charlie [Richardson], one to Mr. Proctor, and one retained by Huddleston (and now in the JEC Hodges Collection, 77-1/1-14). One of the boat-shaped effigy bowls is illustrated in Suhm and Jelks (1962:Plate 21E) and in Newell and Krieger (1949:Fig. 63H), but is not in the HSU Museum Collection.]

The bottles are characterized by having necks that are as tall or taller than the body of the bottle. All the necks are smaller at the top than at the base, but in a few cases there is a flare at the top. The tallest bottle was fourteen inches. All were red slipped and most of them were plain. In the decorated bottles, the motif consisted of either engraved or incised lines around the top of the body of the bottle. The body of one is entirely decorated with incised parallel lines which extend from the base of the neck to the bottom of the bottle. The lines are about one-fourth inch apart and are heavy. Another bottle has four broken engraved lines circling the top of the body and the remainder of the body divided into four sections each surrounded with two concentric circles. Within the circles there are interlocking angular lines and semicircles with no apparent motif.

There were a number of beaker shaped jars or bowls having all most perpendicular sides with flat bottoms. About three-fourths of them were decorated and always in the same manner; four to six lines around the top on a slightly thickened portion of the rims. All of these beakers were treated with a red slip and have pierced rims for suspending. Harrington (1920:Plate LXIX-LXXX) shows similar forms from the Washington site. Lines are overhanging as in the Coles Creek Culture (Ford 1936:172-218). Five similar pieces were semi-globular in shape but in ware, decoration, and piercing of the rims, were the same.

The vase forms ranged in size from three inches tall to ten inches. All were incised using as motifs alternate meandering lines and punctates, herringbone motifs, or parallel lines. The body of one is completely covered with small punctates arranged in rows parallel 
to the base. [Eds.: Sentence missing? Discussion shifts from jars to East Incised bowls.] They ranged in diameter from four to eight inches and all but one were decorated with a rich red slip and parallel lines around the rim on a thickened wall. These bowls have two rim projections opposite each other which consists of a flattened top wide enough to permit the incising of a circle with a triangle on each side and a shrinking of the outside of the rim just under this flat top. In incising seven of the slip pieces the slip was applied often by pipe. [Eds.: Meaning unclear.]

Pipes. All the pipes found were similar with one exception. Harrington (1920:Plate CIV) found one similar to this from the Hot Springs site. [Eds.: Harrington visited several sites in the Upper Ouachita River drainage near Hot Springs, Arkansas.] Five of the long stem type were found; the shortest was five inches and the longest twenty three inches. These pipes are very delicate and the bowl is very small. They were probably for ceremonial purposes only. All had been treated with a red slip and showed evidence of use. Harrington (1920) and Lemley [Eds.: either refers to Dickinson and Lemley 1939 or Lemley 1936] and Moore (1912) found similar types. All the pipes had apparently been stood against the wall of the grave near the head. One had either fallen into or had been placed in a bowl.

Arrowpoints. In all, seven graves yielded caches of arrows ranging in number from nine to thirty eight. In every case they were pointing in the same direction. All points were very expertly and delicately chipped of red, brown, gray, and white flint and novaculite and ranged in length from one-half to two and one-half inches. Similar types have been found at Gahagan (Webb and Dodd 1939), Haley Place (Moore 1912), Crenshaw site [Eds.: either refers to Dickinson 1936 or Lemley 1936], and Mineral Springs (Harrington 1920). In one small beaker with pierced rim there were ten small arrows. [Eds.: While Huddleston's notes indicate caches of arrowpoints were found in Graves B, C, F, and G, none have specifically been identified in the JEC Hodges Collection. Similar caches of arrowpoints or quivers of arrows have been described from deep graves at several of these other sites (as well as at Cahokia's Mound 72, later in the $20^{\text {th }}$ century [Fowler et al. 1999]).]

Copper. Traces of copper were found in four graves. In no case was there enough left to indicate its usage other than a part of clothing. Under one piece there were two short pieces of twisted cord possibly part of a robe. There were two semi-spherical objects which appeared to be halves of nuts that had been covered with copper. [Eds.: Huddleston's notes indicate two copper-covered objects in Graves D and E, not identified in JEC Hodges Collection.]

Polished Stone. Six graves yielded beautifully polished celts which apparently had been placed near the hand of the body but bone was so completely gone as to make this only a guess. In four graves there were large crystals placed in about the same position; these ranged in length from five to nine inches and were from three-fourths to one and one-fourth inches in diameter. There was one pair of round slate ear spools three and one-half inches in diameter. Both showed evidence of having been copper covered.

Skeletal Material. Evidences of skeletons were observed in only one grave. This appeared to be a cremation. Only the skull remained so that it could be preserved. A 
considerable amount of ash and charcoal was packed on the grave floor and around the bones and artifacts. The skull was badly crushed. [Eds.: Huddleston's notes indicate a crushed vessel and skull in ash were found in Grave A; the skull was given a catalog number, but has not been linked with human remains in the JEC Collection. The human remains tentatively identified from East in the collection were found in vessel 1-40 with no further information (Table 1).]

Other Materials. A piece of galena was found in one grave. It was about the size of a walnut and unworked except for a hole pierced through the thin side. One wood ornament was found. [Eds.: This wood artifact (77-1/1-11, Figure 6) was apparently found by Dr. Richie in 1942.] It had been burned and was about the consistency of charcoal which would account for its preservation. It is probably walnut and was carved to represent a wood duck head. Lines across the top and on the sides had been filled with yellow red and white ocher. There was a projection from the underneath side suggesting a neck which was probably the means of fastening it to a hollow cane or stick.

Summary. Contrasts with the usual Caddo burials of the surrounding area:

a. Most of the pottery is either red slip or red ware.

b. All tempering is either sand or grit, no shell.

c. Tall necked bottles with tapering sides from top to base.

d. Large crystals in burials.

e. Arrows are excellently chipped and shaped considerably different from those found on Caddo sites or graves.

f. Pipe stems are long and delicately made with the portion of the stem extending beyond the bowl cut square off. In Caddo burials where similar pipes have been found the stems are larger and extend to a point beyond the bowl.

g. Copper covered ear spools and other copper covered objects.

h. Beaker shaped vessels with pierced rims.

i. Caho Ka type arrow points. [Eds.: Huddleston footnotes "Cahoaka" but does not provide a reference on the Cahokia site.]

j. Parallel lines around rim of vessels similar to Coles Creek (Ford 1936).

k. Mound arrangement not typically Caddo.

I. No seed jars or cazuellas.

\section{Editors' Discussion: Documentation of Huddleston's East Vessels}

A total of 45 of Huddleston's vessels from East Place (3CL21) have been identified in the JEC Hodges Collection (the Hodges Collection was accessioned as 77-1, each site was coded with a number, such as 1 for 3CL21, and each artifact identified to 3CL21 was assigned a unique number, $-1,-2,-3$; see Appendix). These have been documented using a protocol first developed by Ann Early for use on the HSU Museum vessel collections and recently revised by Early and Leslie Walker (2014) as part of the Arkansas Archeological Survey's digital vessel database initiative. The record form includes attributes of form and shape, paste and temper, measurements, decorative treatment, evidence of use, and associations. The East Place vessels were documented between 1999 and 2014 at the Arkansas Archeological Survey's HSU Research Station, first under Ann Early's and then under Mary Beth Trubitt's supervision. While there have been some changes in the recording protocol during this time (for example, "grit" often referred to "claygrit" or grog rather than crushed rock temper in earlier years), the results are comparable. Decorative treatments to vessel rim and 
body use the collegiate or descriptive system, developed for use on Caddo vessels in southern Arkansas (e.g., Early, ed., 1993; Schambach and Miller 1984), that uses named patterns and numbered design variations within each pattern. Some of the East vessels represent "type examples" for specific design variations (Figure 7). Type and variety names follow Early (ed., 1993) and Suhm and Jelks (1962). While black and white photographs were taken in 1977-1978, documentation of vessels in the JEC Hodges Collection at the Arkansas Archeological Survey's HSU Research Station since 1999 has also included color slides and digital photographs. Site collections that include Huddleston vessels and records have been prioritized, with an effort made to identify associated funerary objects that can be linked with human remains in the JEC Hodges Collection (Trubitt 2012b).

$$
\text { JEC Hodges Collection Vessel } \frac{77-1}{1-2}
$$

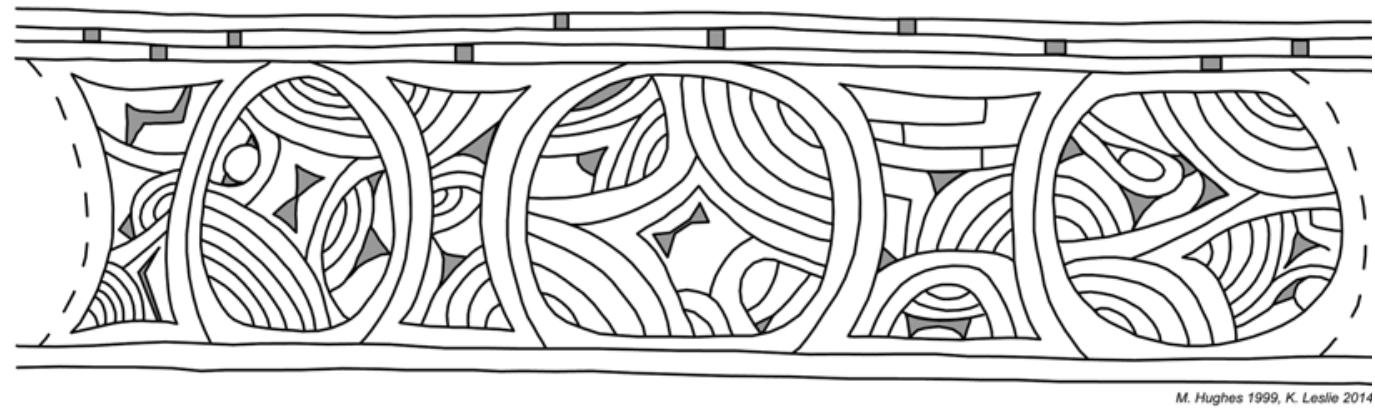

M. Hughes 1999 K K Leslio 2014

Figure 7. Illustration of new Evangel 1 pattern and design from engraved bottle 77-1/1-2, Huddleston's Grave B
(roll-out drawing by Milton Hughes and Katie Leslie, Arkansas Archeological Survey, 1999 and 2014).

The JEC's Hodges Collection contains about 55,000 objects, most of which are stone tools and broken pottery pieces. The collection also includes about 1300 whole, partial, or reconstructed vessels (Early 1978). JEC Hodges Collection artifacts were first exhibited at the HSU Museum in 1981; displays on the campuses of Henderson State University and Ouachita Baptist University began in 1996, and there are currently four venues with exhibits from this collection in Arkadelphia. Following the passage of the Native American Graves Protection and Repatriation Act or NAGPRA in 1990, inventories and notifications were done for HSU Museum and Arkansas Archeological Survey collections. The Joint Educational Consortium, made up of Henderson State University and Ouachita Baptist University (and the Ross Foundation at one time), initially maintained that their collection was outside the scope of NAGPRA, but did send a summary to the Caddo Nation in 1995. More recently, JEC officials have consulted with and met with representatives of the Caddo Nation about the collection.

Based on his notes, Vere Huddleston dug graves at East Place (3CL21) between April, 1939, and January, 1943. In 1939, Huddleston dug 7 graves that included pottery styles that he had previously seen on other sites in the Middle Ouachita River region (Table 1, Graves 1-7). Fifteen vessels from these graves have been identified in the JEC Hodges Collection. Shell and grog-and-shell temper predominates in vessels in the four grave lots represented. Vessel shapes (carinated bowls described as cone-shaped by Huddleston, bottles with short spool necks and everted lips, sometimes pedestalled), and types (Means Engraved, Keno Trailed variety Red Hill) indicate late Social Hill or Deceiper phase assignment (Early 2002c, d; Early, ed., 1993) for Huddleston's Grave 1/2, 3, and 7 (Figure 8). There are similarities with Middle Ouachita River sites such as Hardman (Early, ed., 1993). One grave lot (Huddleston's Grave 4, with a brushed/punctated jar, a carinated 
Glassell Engraved bowl, and two notched rim bowls similar to Hardman Engraved but plain) probably dates to the late Mid-Ouachita or Social Hill phase (Early, ed., 1993). Bottles ( $n=4)$ and carinated bowls ( $n=6$, of 15) are the most common vessel form in this set, but there are vessels from these graves that are missing (possibly in HSU Museum Collections).
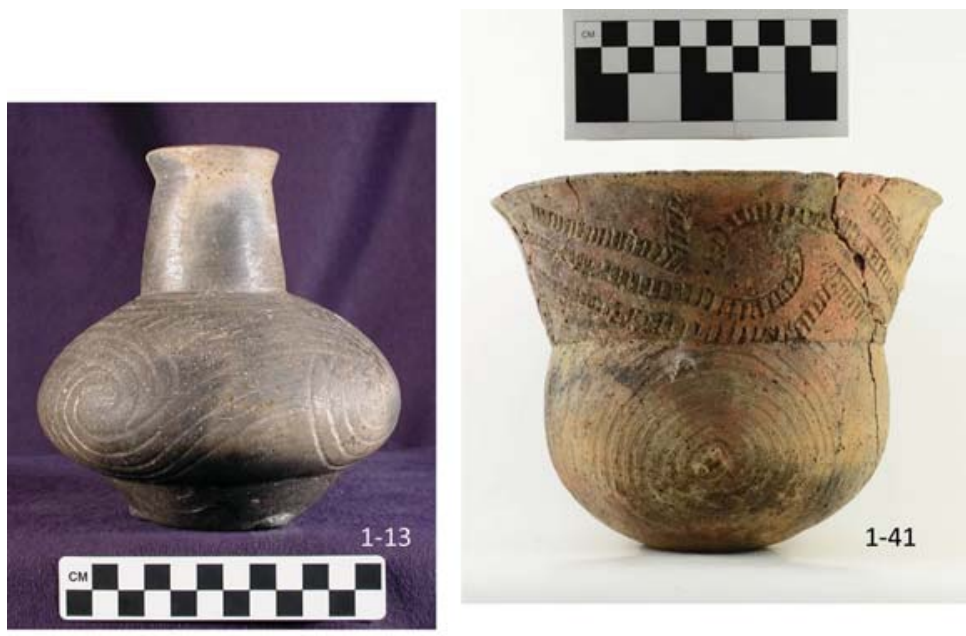

3CL21 - Huddleston Grave 3 (4/29/1939)

(late Social Hill to Deceiper phase)
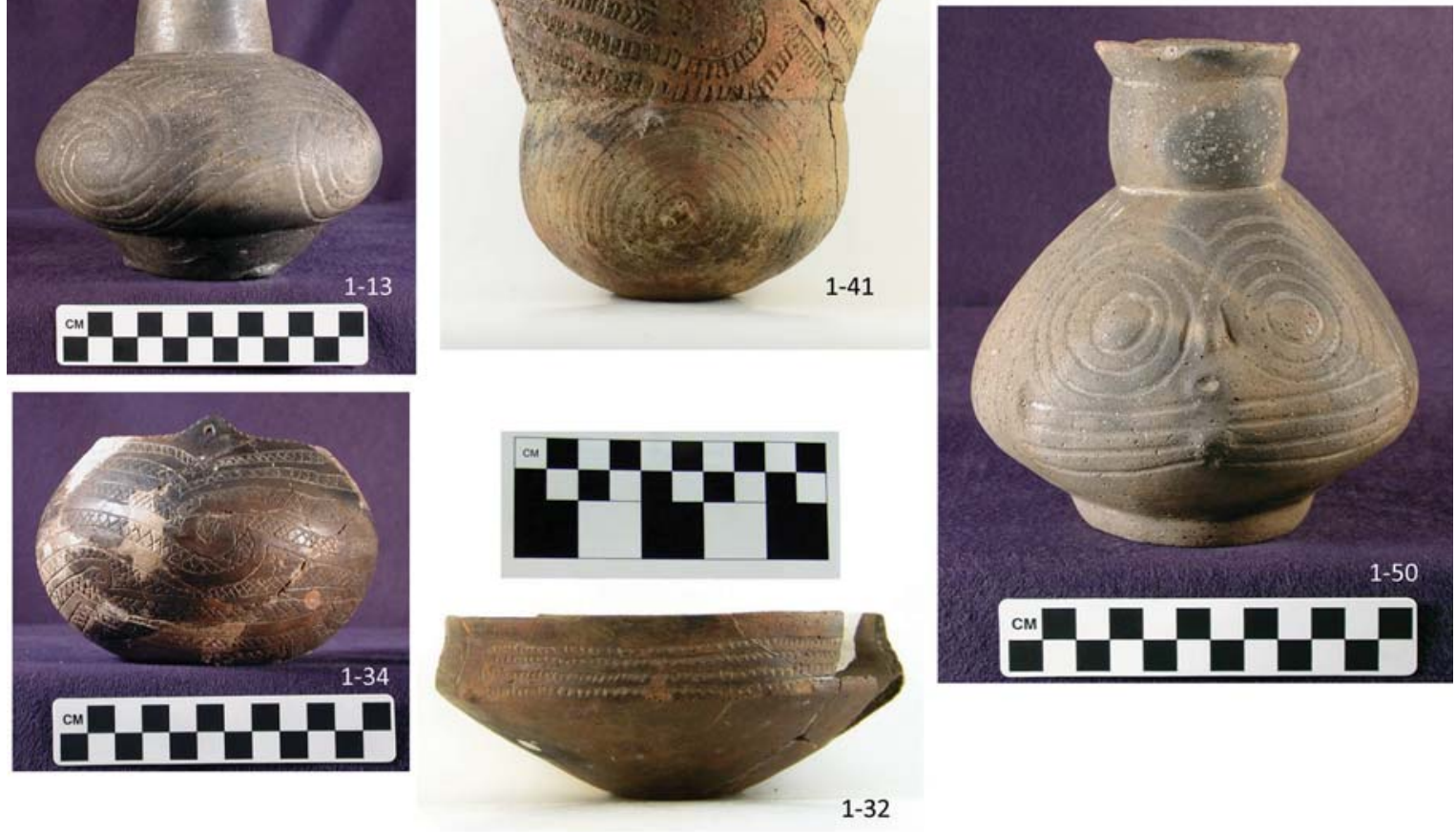

Figure 8. JEC Hodges Collection vessels linked to Huddleston's Grave 3, excavated from East Place in 1939 (Arkansas Archeological Survey digital photographs).

Between May of 1941 and January of 1943, Huddleston dug 11 graves at East, several of which were in a mound or mounds, sometimes deep (4-6' below surface) but occasionally shallow (18"). Huddleston recognized that the artifacts represented a different and earlier time period in the site's occupational history. Thirty vessels from this group have been identified in the JEC Hodges Collection, as well as 1 celt, 1 pipe, and 2 quartz crystals. The vessels are predominantly tempered with grog and include tall plain or red-slipped Smithport Plain, Hickory Fine Engraved, and Spiro Engraved bottles, East Incised bowls and beakers, and jars with rectilinear incising and punctating typed as Pease Brushed-Incised (Figure 9, 10). Most of these grave lots indicate an East phase component at the site (Early 2002a; Early, ed., 1993), or early Mid-Ouachita phase (grog-tempered Military Road Incised, Adair Engraved). Jars ( $n=11)$, bottles $(n=8)$, and beakers ( $n=7$, of 30) are the most common vessel form of this set, but again, all the vessels from these graves are not present in the JEC Hodges Collection. 


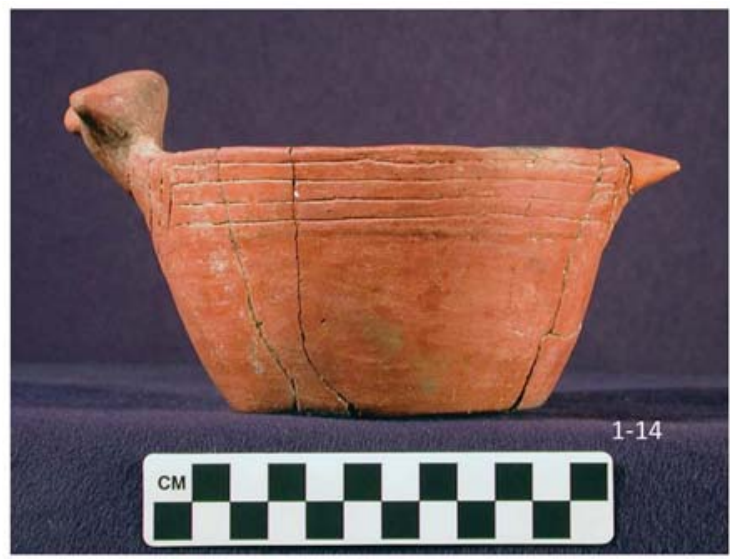

$3 \mathrm{CL} 21-$

Huddleston Grave B

$(11 / 21 / 1942)$

(East phase)
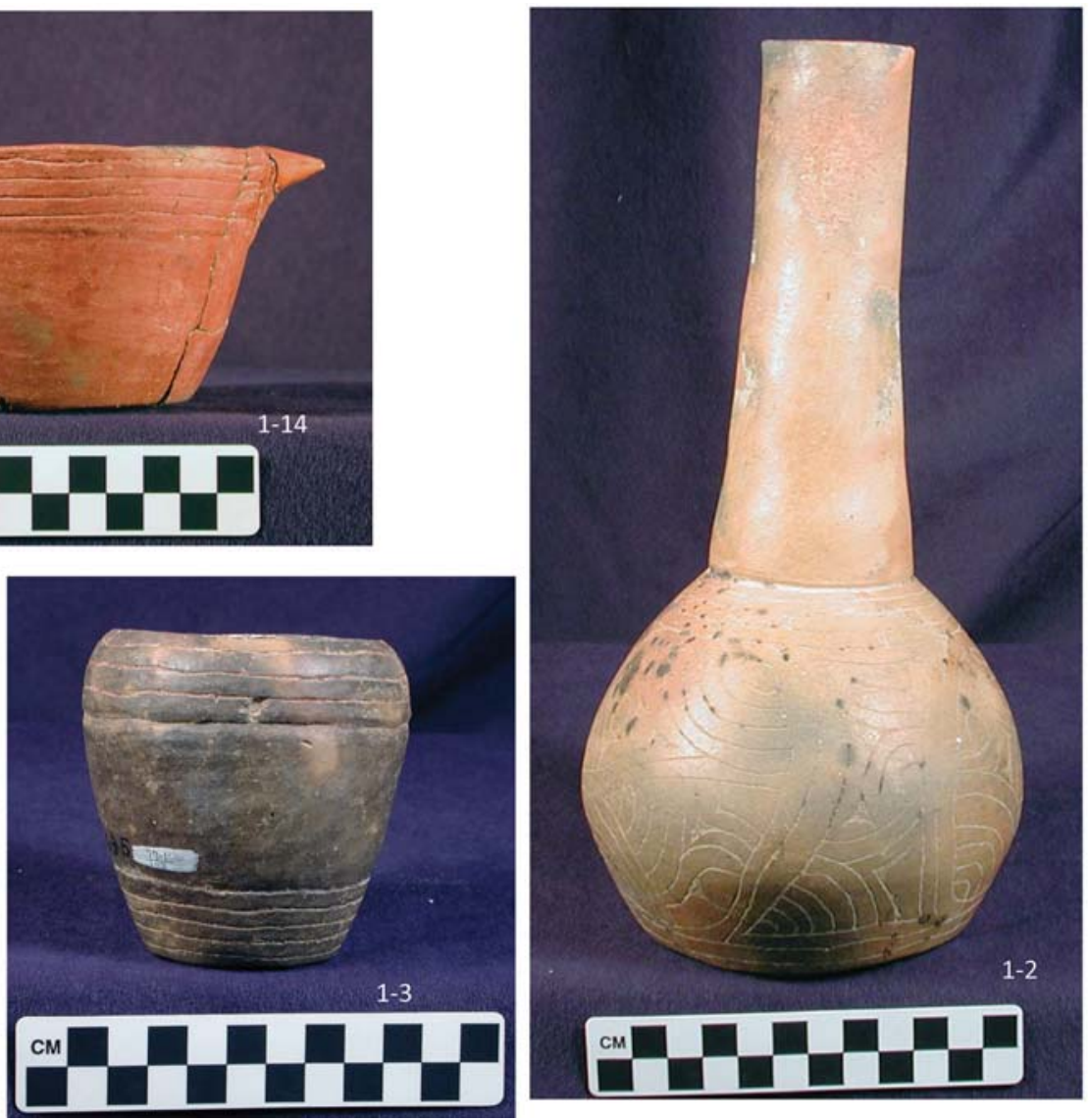

Figure 9. JEC Hodges Collection vessels linked to Huddleston's Grave B, excavated from East Place in 1942 (Arkansas Archeological Survey digital photographs).

One small jar (77-1/1-40) had no provenience or context information other than site. It is tempered with grog and grit (abundant mica), and plain, with red color from firing or possible red ochre rather than an applied slip. The shape is unusual for this region, and its assignment to 3CL21 may be in error. Human bone fragments were found in the jar that may have come from the same grave, but there is no identification or notes, so the context is unclear. The vessel and the human remains are interpreted as associated at this time. No other human remains in the JEC Hodges Collection have been identified or linked to East Place (3CL21).

There are similarities between the East phase burial vessels from East and vessels at Crenshaw (3MI6) in the Red River valley, as noted by Huddleston in his manuscript. Early Caddo vessels documented from Crenshaw by Perttula and colleagues (2014) also included East Incised, Hickory Engraved, Smithport Plain, and Spiro Engraved types, but that assemblage also included numerous Crockett Curvilinear Incised and Haley Complicated Incised vessels, not documented in this collection from East (although Huddleston's sketches show several examples in Proctor's collection from the site). Pease Brushed-Incised vessels were assigned to Middle Caddo contexts at Crenshaw (Perttula et al. 2014). Hickory Engraved bottles and Pease Brushed-Incised jars are also well represented in the assemblage excavated by Harrington from the Ozan sites and Washington, although Hempstead Engraved, Crockett Curvilinear Incised, Sinner Linear Punctated, and Haley Complicated Incised are found there and not in this East collection (Gonzalez et al. 2005; Harrington 1920). Hays Mound (3CL6), in the Little Missouri River valley, was salvaged as it was being leveled in 1971 (Weber 1973). With dates ranging between A.D. 1000-1400 and a sherd assemblage that includes many types and surface treatments seen at East, Hays is an important comparison but needs an updated artifact 


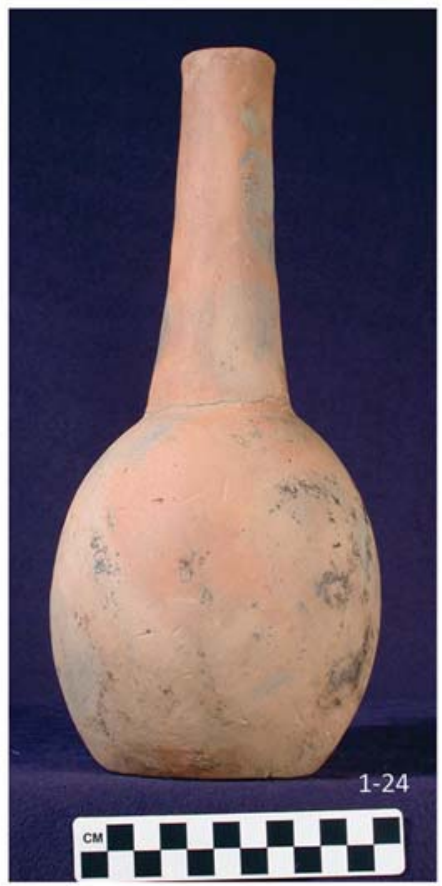

$3 \mathrm{CL} 21$ -

Huddleston Grave F (1/1/1943)

(East phase)
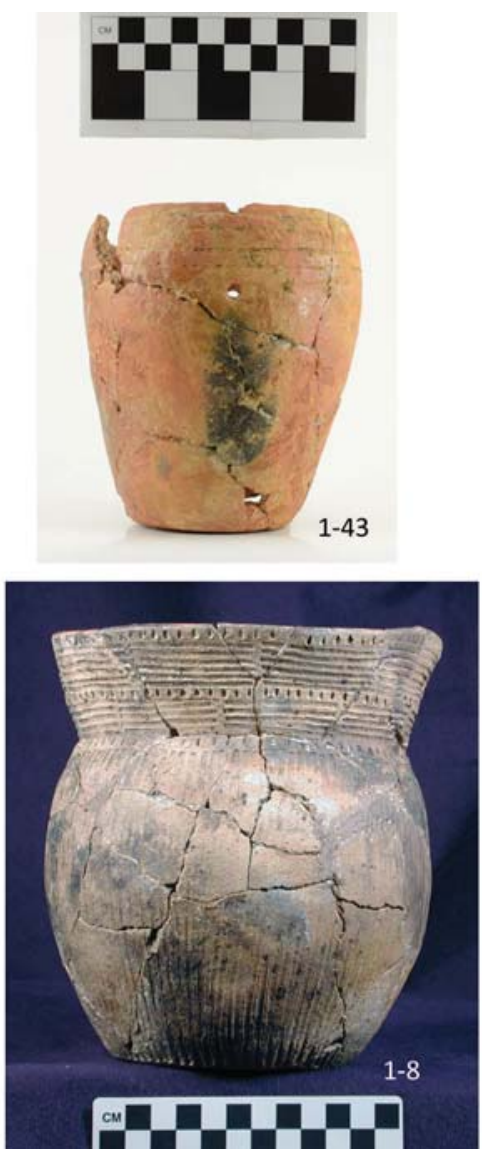
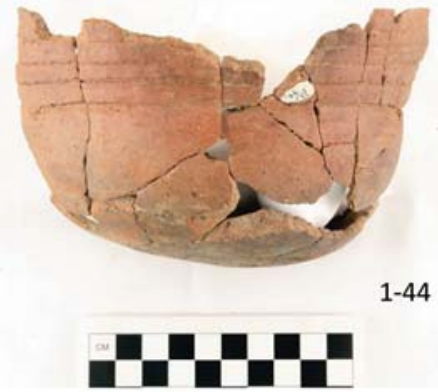

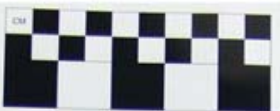

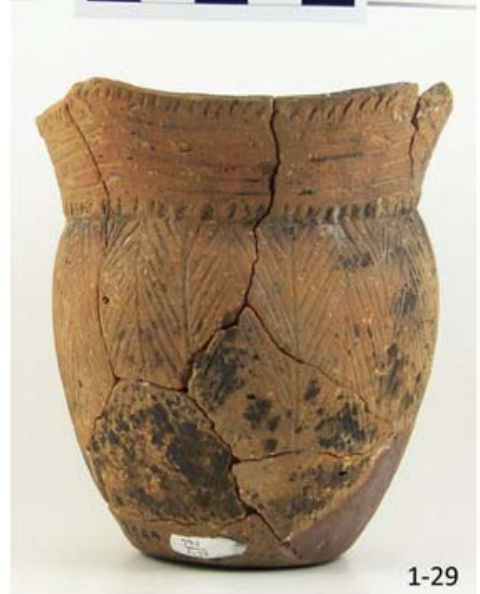

Figure 10. JEC Hodges Collection vessels linked to Huddleston's Grave F, excavated from East Place in 1943 (Arkansas Archeological Survey digital photographs).

analysis (Early 2002a; Trubitt 2009; Weber 1973). Excavations at 3CL401 (Ross), a mound site in the Little Missouri River valley, produced sherds of similar pottery (Early 1984). From the Middle Ouachita River valley, comparisons can be made with lower levels excavated at 3CL27 (Bayou Sel) and the lower structure and premound midden at 3CL593 (Caddo Valley Mound) (Trubitt 2009).

Huddleston's work at East Place (3CL21) has played an important role in the history of Caddo archaeology. Many of the vessels he and the other Arkadelphia amateur archaeologists dug from graves at the site in the 1930s-1940s were used to illustrate and later define the initial Caddo presence in the Middle Ouachita River region in Arkansas, now defined as the East phase, ca. 1100-1400 A.D. Based on the vessels and reconstructed Huddleston grave lots, it is clear that the use of the site extended to the Deceiper phase, ca. 1650-1700 A.D. The manuscript that Huddleston wrote, reproduced here, provides some context for the artifacts.

\section{Acknowledgements}

Original Huddleston and Hodges notes are curated at HSU Archives, and the JEC Hodges Collection artifacts are curated at Henderson State University in Arkadelphia, Arkansas. The East Place vessels were documented between 1999 and 2014 at the Arkansas Archeological Survey's HSU Research Station by Florence Davis, Mary Ann Goodman, Ann Early, Jeffrey Gaskin, Vanessa Hanvey, Jim Hudgins, Milton Hughes, Judy Thye, Mary Beth Trubitt, and Kate Wright. JEC Hodges Collection documentation has been funded in part by a 2006 grant from the Ross Foundation. We appreciate comments on an earlier version of this manuscript by Ann M. Early, as well as suggestions by the two reviewers prior to publication. 


\section{References Cited}

Berry, Trey, Pam Beasley, and Jeanne Clements

2006 The Forgotten Expedition, 1804-1805: The Louisiana Purchase Journals of Dunbar and Hunter. Louisiana State University Press, Baton Rouge.

Dickinson, S. D.

1936 The Ceramic Relationships of the Pre-Caddo Pottery from the Crenshaw Site. Bulletin of Texas Archeological and Paleontological Society 8:56-69.

Dickinson, S. D. and Harry J. Lemley

1939 Evidences of the Marksville and Coles Creek Complexes at the Kirkham Place, Clark County, Arkansas. Bulletin of the Texas Archeological and Paleontological Society 11:139-189.

Early, Ann M.

1978 A Guidebook to the T. L. Hodges Collection of Prehistoric and Historic Artifacts, Fossils and Minerals. Joint Educational Consortium, Arkadelphia, Arkansas. Ms. on file, Arkansas Archeological Survey, HSU Research Station, Arkadelphia.

1982 Caddoan Settlement Systems in the Ouachita River Basin. In Arkansas Archeology in Review, edited by Neal L. Trubowitz and Marvin D. Jeter, pp. 198-232. Research Series No. 15, Arkansas Archeological Survey, Fayetteville.

1984 Survey and Testing of the Ross Site (3CL401). Limited distribution report, on file at Arkansas Archeological Survey, HSU Research Station, Arkadelphia.

1986 Dr. Thomas L. Hodges and His Contribution to Arkansas Archeology. The Arkansas Archeologist 23-24:1-9.

1993 Finding the Middle Passage: The Spanish Journey from the Swamplands to Caddo Country. In The Expedition of Hernando de Soto West of the Mississippi, 1541-1543, edited by Gloria A. Young and Michael P. Hoffman, pp. 68-77. University of Arkansas Press, Fayetteville.

2002a Arkansas Prehistory and History in Review: The East Phase. Field Notes: Newsletter of the Arkansas Archeological Society 304:4-8.

2002b The Mid-Ouachita Phase. Field Notes: Newsletter of the Arkansas Archeological Society 305:10-13.

2002c Arkansas Prehistory and History in Review: The Social Hill Phase. Field Notes: Newsletter of the Arkansas Archeological Society 306:10-13.

2002d Arkansas Prehistory and History in Review: Deceiper Phase. Field Notes: Newsletter of the Arkansas Archeological Society 307:8-11.

2012 Form and Structure of Prehistoric Caddo Pottery Design. In The Archaeology of the Caddo, edited by Timothy K. Perttula and Chester P. Walker, pp. 26-46. University of Nebraska Press, Lincoln.

Early, Ann M., editor

1993 Caddoan Saltmakers in the Ouachita Valley: The Hardman Site. Research Series No. 43, Arkansas Archeological Survey, Fayetteville.

Evans, Linda

2011 Interview with Hoy Furr. Henderson State University Archives, Arkadelphia, Arkansas.

2012 Amateur Archeologists in the Ouachita River Valley during the Great Depression. Master of Liberal Arts thesis, Henderson State University, Arkadelphia, Arkansas.

Ford, James A.

1936 Analysis of Indian Village Site Collections from Louisiana and Mississippi. Anthropological Study Number 2, Department of Conservation, Louisiana Geological Survey, New Orleans, Louisiana.

Fowler, Melvin L., Jerome Rose, Barbara Vander Leest, and Steven R. Ahler

1999 The Mound 72 Area: Dedicated and Sacred Space in Early Cahokia. Illinois State Museum Reports of Investigations No. 54, Illinois State Museum Society, Springfield. 
Girard, Jeffrey S., Timothy K. Perttula, and Mary Beth Trubitt

2014 Caddo Connections: Cultural Interactions within and beyond the Caddo World. Rowman \& Littlefield, Lanham, Maryland.

Gonzalez, Bobby, Robert Cast, Timothy K. Perttula, and Bo Nelson

2005 A Rediscovering of Caddo Heritage: The W. T. Scott Collection at the American Museum of Natural History and Other Caddo Collections from Arkansas and Louisiana. Historic Preservation Program, Caddo Nation of Oklahoma, Binger.

Harrington, M. R.

1920 Certain Caddo Sites in Arkansas. Museum of the American Indian. Heye Foundation, New York.

Historic Arkansas Museum

2014 Museum Collection: Pottery of Caddo. Electronic document, http://www.historicarkansas.org/ collections/pottery-caddo.aspx, accessed December, 2014.

Hodges Collection

Thomas and Charlotte Hodges Collection - V. L. Huddleston papers, Local and HSU History Collections, RG41, SG04. Henderson State University Archives, Arkadelphia, Arkansas.

Hodges, T. L. and Mrs. [Charlotte]

1945 Suggestion for Identification of Certain Mid-Ouachita Pottery as Cahinnio Caddo. Bulletin of the Texas Archeological and Paleontological Society 16:98-116.

Huddleston, V. L.

1943 Indians in Clark County. Arkansas Historical Quarterly 2(2):110-115.

Lemley, H. J.

1936 Discoveries Indicating a Pre-Caddo Culture on Red River in Arkansas. Bulletin of the Texas Archeological and Paleontological Society 8:25-55.

Moore, Clarence B.

1912 Some Aboriginal Sites on Red River. Journal of the Academy of Natural Sciences of Philadelphia 14(4):483-638.

Morrow, Juliet E., Sarah Stuckey, and Claire Nix

2014 The Archeological Collections of Odis and Nell Sullivan: A Recent Donation to the Arkansas Archeological Survey. Paper presented at the 2014 Annual Meeting of the Arkansas Archeological Society, October, 2014, Springdale, Arkansas.

Newell, H. Perry and Alex D. Krieger

1949 The George C. Davis Site, Cherokee County, Texas. Memoir No. 5, Society for American Archaeology (published as American Antiquity vol. 14, no. 4, part 2).

Perttula, Timothy K., Bo Nelson, Mark Walters, and Robert Cast

2014 Documentation of Caddo Funerary Objects from the Crenshaw Site (3MI6) in the Gilcrease Museum Collections. Special Publication No. 19, Friends of Northeast Texas Archaeology, Pittsburg and Austin, Texas.

Richter, Wendy

1992 V. L. Huddleston. In Clark County Arkansas: Past and Present, edited by Wendy Richter, pp. 563564. Clark County Historical Association, Arkadelphia, Arkansas. 
Schambach, Frank F.

\section{References Cited (cont.)}

1993 The End of the Trail: Reconstruction of the Route of Hernando De Soto's Army through Southwest Arkansas and East Texas. In The Expedition of Hernando de Soto West of the Mississippi, 15411543, edited by Gloria A. Young and Michael P. Hoffman, pp. 78-105. University of Arkansas Press, Fayetteville.

Schambach, Frank F. and John E. Miller

1984 A Description and Analysis of the Ceramics. In Cedar Grove: An Interdisciplinary Investigation of a Late Caddo Farmstead in the Red River Valley, edited by Neal L. Trubowitz, pp. 109-170. Research Series No. 23. Arkansas Archeological Survey, Fayetteville.

Suhm, Dee Ann and Edward B. Jelks, editors

1962 Handbook of Texas Archeology: Type Descriptions. Special Publication No. 1, Texas Archeological Society, and Bulletin No. 4, Texas Memorial Museum, Austin.

Swanton, John R., chairman

1939 Final Report of the United States De Soto Expedition Commission. United States Government Printing Office Washington, D. C.

Trubitt, Mary Beth

2007 Documentation of the Joint Educational Consortium's Hodges Collection. Paper presented at the 49th Caddo Conference, March 15-18, 2007, Magnolia, Arkansas.

2009 Burning and Burying Buildings: Exploring Variation in Caddo Architecture in Southwest Arkansas. Southeastern Archaeology 28(2):233-247.

2012a Topographic Mapping of a Caddo Mound in Clark County. Field Notes: Newsletter of the Arkansas Archeological Society 364:9-11.

2012b New Information from Old Collections: Analyzing Caddo Mortuary Ceramics from the Middle Ouachita River Valley. Paper presented in symposium (co-organized by D. P. McKinnon and E. L. Dowd) at the $69^{\text {th }}$ Annual Meeting of the Southeastern Archaeological Conference, November, 2012, Baton Rouge, Louisiana.

Walker, Leslie

2014 Liminal River: Art, Agency and Cultural Transformation Along the Protohistoric Arkansas River. Ph.D. dissertation, Department of Anthropology, University of Arkansas, Fayetteville.

Webb, Clarence $\mathrm{H}$.

1948 Caddoan Prehistory: The Bossier Focus. Bulletin of the Texas Archeological and Paleontological Society 19:100-147.

Webb, C. H. and Monroe Dodd Jr.

1939 Further Excavations on the Gahagan Mound: Connections with a Florida Culture. Bulletin of the Texas Archeological and Paleontological Society 11:92-126.

Weber, J. Cynthia

1972 Ceramics of the East Mounds (3CL21). Unpublished ms., on file at the Arkansas Archeological Survey, Arkadelphia and Fayetteville.

1973 The Hays Mound, 3CL6, Clark County, South Central Arkansas. Report on research conducted under cooperative agreement between the National Park Service Southeast Region and the Arkansas Archeological Survey. Unpublished ms., on file at the Arkansas Archeological Survey, Arkadelphia and Fayetteville.

Wolfman, Daniel

1982 Archeomagnetic Dating in Arkansas and the Border Areas of Adjacent States. In Arkansas Archeology in Review, edited by Neal L. Trubowitz and Marvin D. Jeter, pp. 277-300. Research Series No. 15, Arkansas Archeological Survey, Fayetteville. 


\title{
Revisiting a Historic Manuscript: \\ Vere Huddleston's Report on East Place (3CL21) Excavations
}

\author{
Edited by \\ Mary Beth Trubitt (Arkansas Archeological Survey) and \\ Linda Evans (Henderson State University)
}

APPENDIX:

EAST PLACE VESSEL DOCUMENTATION 
JEC Hodges Collection, 77-1

East Place, 3CL21

Item No./Hodges Catalog

Vessel Form

AAS/HSU Digital Photo No.

Type

Decoration

Rim :: Body

Paste

Temper

Color, Core

Color, Exterior

Color, Interior

Overall Height cm

Weight g

Volume liters

Use/Wear/Condition

Shape / Description

Lip Treatment

Orifice Diameter $\mathrm{cm}$

Rim Height cm

Rim Thickness cm

Rim Surface Treatment

Rim Decorative Treatment

Rim/Neck Shape

Body Maximum Diameter cm

Body Height cm

Body Thickness cm

Body Surface Treatment

Body Decorative Treatment

Body Shape

Base Shape

Base Diameter $\mathrm{cm}$

Base Height cm

Base Surface Treatment

Base Decorative Treatment

Appendages

Notes

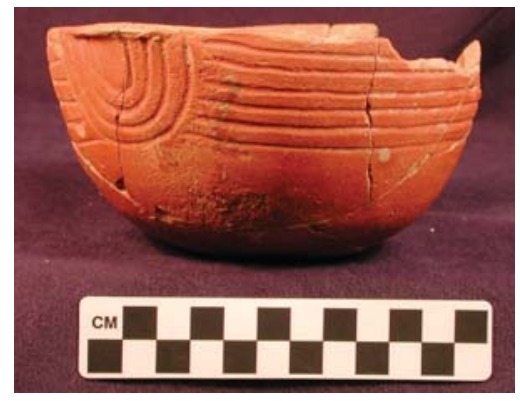

1-1, 2491

bowl, simple

1773

East Incised

red slipped/incised

Barrington 9 (type) :: plain

SOFT, SLIGHTLY CRUMBLY

GROG \& GRIT

GRAY

RED

STRONG BROWN

FIRECLOUD ON BASE; SOME SURFACE SCRATCHING ON INSIDE BOWL BOTTOM (RECENT?)

ROUND, SHORT; DIRECT RIM FROM ROUND, CONVEX BASE TO LIP

ROUNDED, NO ANGLE

14.4

7.5

.4

SMOOTHED \& SLIPPED \& INCISED

RED SLIP, 6 HORIZONTAL 2MM-WIDE INCISED LINES SPACED 4 CM APART; 4 NESTED U-SHAPED INCISED LINES UNDER RIM TAB

STRAIGHT, VERTICAL/DIRECT

CONVEX

CIRCULAR, CONVEX

7.5

HANDLES, 2 TABS AT RIM, INCISED ON TOP

Huddleston Grave X, 5/9/1941 (with 1-5, 1-9, 1-28), East phase 
JEC Hodges Collection, 77-1 East Place, 3CL21

\section{Item No./Hodges Catalog}

Vessel Form

AAS/HSU Digital Photo No.

Type

Decoration

Rim :: Body

Paste

Temper

Color, Core

Color, Exterior

Color, Interior

Overall Height cm

Weight g

Volume liters

Use/Wear/Condition

Shape / Description

Lip Treatment

Orifice Diameter cm

Rim Height cm

Rim Thickness cm

Rim Surface Treatment

Rim Decorative Treatment

Rim/Neck Shape

Body Maximum Diameter cm

Body Height cm

Body Thickness cm

Body Surface Treatment

Body Decorative Treatment

Body Shape

Base Shape

Base Diameter $\mathrm{cm}$

Base Height cm

Base Surface Treatment

Base Decorative Treatment Appendages

Notes

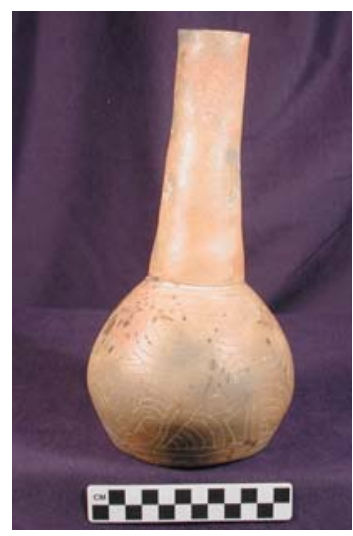

1-2, 2696

bottle

1783

Spiro Engraved?

red slipped/engraved

plain :: Evangel 1

HARD, FINE, COMPACT

GROG \& GRIT

REDDISH

STRONG REDDISH BROWN, TAN, LIGHT GRAY

FIRECLOUDS, RED SLIP WORN OFF IN PLACES, BOTTOM ROUGH LONG NECK BOTTLE W/ FLAT, ROUND BASE, GLOBULAR BODY ROUNDED, SLIGHTLY EVERTED

4.2

15.5

.5

SMOOTHED \& SLIPPED

RED SLIPPED

INSLOPING, LONG NECKED

13.2

10.6

SMOOTHED \& SLIPPED \& ENGRAVED

CURVILINEAR ENGRAVING/EXCISING, 3 CIRCULAR PANELS

GLOBULAR

CIRCULAR, FLAT

9.9

Huddleston Grave B, 11/21/1942 (with 1-3, 1-14), East phase; previous illustration Newell \& Krieger 1949: Fig. 65A 
JEC Hodges Collection, 77-1

East Place, 3CL21

Item No./Hodges Catalog

Vessel Form

AAS/HSU Digital Photo No.

Type

Decoration

Rim :: Body

Paste

Temper

Color, Core

Color, Exterior

Color, Interior

Overall Height cm

Weight g

Volume liters

Use/Wear/Condition

Shape / Description

Lip Treatment

Orifice Diameter $\mathrm{cm}$

Rim Height cm

Rim Thickness cm

Rim Surface Treatment

Rim Decorative Treatment

Rim/Neck Shape

Body Maximum Diameter cm

Body Height cm

Body Thickness cm

Body Surface Treatment

Body Decorative Treatment

Body Shape

Base Shape

Base Diameter cm

Base Height cm

Base Surface Treatment

Base Decorative Treatment Appendages

Notes

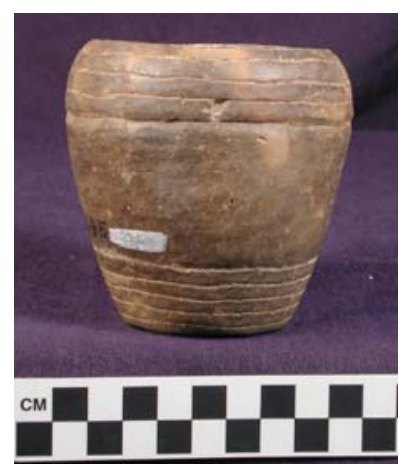

1-3, 2695

beaker

1769

East Incised

incised

Bates 16 (type) :: plain

HARD, FINE, SILTY, COMPACT

GROG \& GRIT

LIGHT GRAY

DARK GRAYISH BROWN, VERY PALE BROWN

VERY DARK GRAY

FIRECLOUDS

SMALL BEAKER - SMALL DIA. ROUND BASE, RIM SLANTS UP \& OUT W/

INSLANTED LIP

ROUNDED

6.9

8.4

.5

SMOOTHED \& BURNISHED \& INCISED

HORIZ. INCISED LINES W/ RED PIGMENT - 4 LINES TOP (.5 CM

SPACING), 5 LINES LOWER BODY (3CM SPACING)

CONVEX, INSLANTED

7.5

OVOID

CIRCULAR, FLAT

4.9

2 SUSPENSION HOLES

Huddleston Grave B, 11/21/1942 (with 1-3, 1-14), East phase; previous illustration Newell \& Krieger 1949: Fig. 65C; Suhm \& Jelks 1962: Plate $21 \mathrm{~L}$ 
JEC Hodges Collection, 77-1

East Place, 3CL21

Item No./Hodges Catalog

Vessel Form

AAS/HSU Digital Photo No.

Type

Decoration

Rim :: Body

Paste

Temper

Color, Core

Color, Exterior

Color, Interior

Overall Height $\mathrm{cm}$

Weight g

Volume liters

Use/Wear/Condition

Shape / Description

Lip Treatment

Orifice Diameter $\mathrm{cm}$

Rim Height cm

Rim Thickness cm

Rim Surface Treatment

Rim Decorative Treatment

Rim/Neck Shape

Body Maximum Diameter cm

Body Height cm

Body Thickness cm

Body Surface Treatment

Body Decorative Treatment

Body Shape

Base Shape

Base Diameter $\mathrm{cm}$

Base Height cm

Base Surface Treatment

Base Decorative Treatment

Appendages

Notes

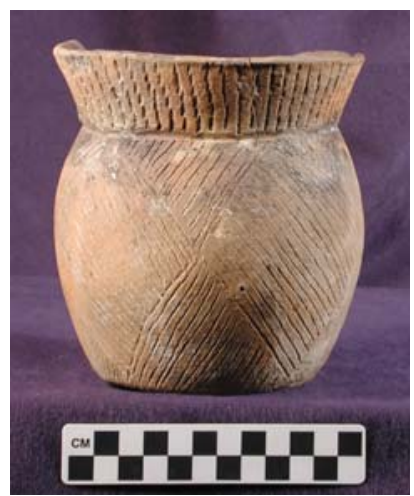

1-4, 2689

jar, tall rim

1765

Pease Brushed-Incised or Dunkin Incised ?

incised/punctated

Caldwell 15 :: Antioch 14 (type)

SOFT

GROG \& GRIT

REDDISH YELLOW

PINKISH GRAY, REDDISH YELLOW, VERY PALE BROWN

DARK BROWN, PALE BROWN

FIRECLOUDS

SQUAT, GLOBULAR JAR W/ TALL FLARING RIM, ROUND BASE, SLIGHTLY OVAL FROM TOP

ROUNDED

13.1

3.2

.5

SMOOTHED \& PUNCTATED

COLUMNS OF VERTICALLY ARRANGED PUNCTATES, EACH 6MM X 1.5

MM

STRAIGHT, OUTSLANTED

13.3

10.7

.5

SMOOTHED \& INCISED

DIAGONALLY ARRANGED INCISED LINES FORMING TRIANGLES \&

DIAMONDS

GLOBULAR, NARROWING TOWARDS BASE, SHARP CURVE TO RIM

CIRCULAR, FLAT

9.1

Huddleston Grave A', 11/14/1942 (with 1-19, 1-30, 1-31, 1-46?), East phase; previous illustration Newell \& Krieger 1949: Fig. 65J 
JEC Hodges Collection, 77-1

East Place, 3CL21

Item No./Hodges Catalog

Vessel Form

AAS/HSU Digital Photo No.

Type

Decoration

Rim :: Body

Paste

Temper

Color, Core

Color, Exterior

Color, Interior

Overall Height cm

Weight g

Volume liters

Use/Wear/Condition

Shape / Description

Lip Treatment

Orifice Diameter cm

Rim Height cm

Rim Thickness cm

Rim Surface Treatment

Rim Decorative Treatment

Rim/Neck Shape

Body Maximum Diameter cm

Body Height cm

Body Thickness cm

Body Surface Treatment

Body Decorative Treatment

Body Shape

Base Shape

Base Diameter $\mathrm{cm}$

Base Height cm

Base Surface Treatment

Base Decorative Treatment

Appendages

Notes

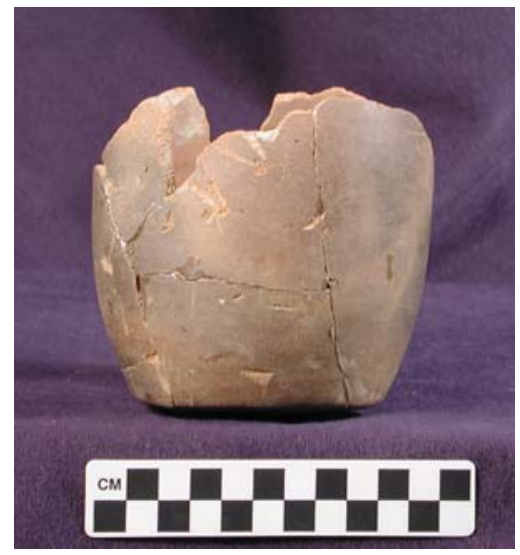

1-5, 2492

beaker

1764

plain

:: plain

MEDIUM, SILTY

GROG \& GRIT

GRAY, PINK

DARK GRAY, PALE BROWN

BROWN, REDDISH BROWN

FIRECLOUDS

BADLY BROKEN, CYLINDRICAL

9.9

.6

SMOOTHED \& BURNISHED

CYLINDRICAL

CIRCULAR, CONVEX

8.5

Huddleston Grave X, 5/9/1941 (with 1-1, 1-9, 1-28), East phase 
JEC Hodges Collection, 77-1 East Place, 3CL21

Item No./Hodges Catalog Vessel Form

AAS/HSU Digital Photo No.

Type

Decoration

Rim :: Body

Paste

Temper

Color, Core

Color, Exterior

Color, Interior

Overall Height cm

Weight g

Volume liters

Use/Wear/Condition

Shape / Description

Lip Treatment

Orifice Diameter cm

Rim Height cm

Rim Thickness cm

Rim Surface Treatment

Rim Decorative Treatment

Rim/Neck Shape

Body Maximum Diameter cm

Body Height cm

Body Thickness cm

Body Surface Treatment

Body Decorative Treatment

Body Shape

Base Shape

Base Diameter $\mathrm{cm}$

Base Height cm

Base Surface Treatment

Base Decorative Treatment Appendages

Notes

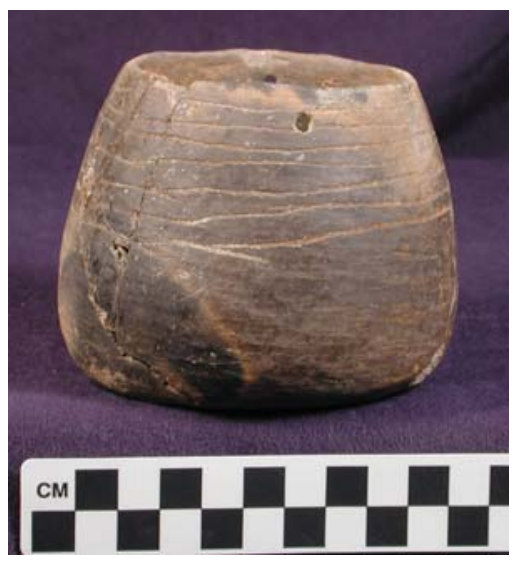

1-6, 2757

beaker

1768

East Incised?

engraved

Eckerd 2 (type) :: plain

HARD, COMPACT

GROG \& GRIT

GRAY

VERY DARK GRAY, VERY DARK GRAYISH BROWN

DARK GRAY

EXTERIOR SURFACE SHOWS SLIGHT UNDULATIONS FROM SMOOTHING

STONE

SQUAT BEAKER, RIM SLANTS IN DIRECTLY FROM BASE

ROUNDED, DIRECT

7.6

7.7

.6

BURNISHED \& ENGRAVED

7 LAZY IRREG ENGRAVED LINES, HORIZ, SPACED 1.5-6.5MM

CONVEX, INSLANTED

10.1

CONCAVE, ELONGATED

CIRCULAR \& FLAT

8.6

2 SUSPENSION HOLES

Huddleston Grave G, 1/16/1943 (with 1-37), East to Mid-Ouachita phase; previous illustration Newell \& Krieger 1949: Fig. 65B; Suhm \& Jelks 1962: Plate 21K 
JEC Hodges Collection, 77-1

East Place, 3CL21

Item No./Hodges Catalog

Vessel Form

AAS/HSU Digital Photo No.

Type

Decoration

Rim :: Body

Paste

Temper

Color, Core

Color, Exterior

Color, Interior

Overall Height cm

Weight g

Volume liters

Use/Wear/Condition

Shape / Description

Lip Treatment

Orifice Diameter $\mathrm{cm}$

Rim Height cm

Rim Thickness cm

Rim Surface Treatment

Rim Decorative Treatment

Rim/Neck Shape

Body Maximum Diameter cm

Body Height cm

Body Thickness cm

Body Surface Treatment

Body Decorative Treatment

Body Shape

Base Shape

Base Diameter cm

Base Height cm

Base Surface Treatment

Base Decorative Treatment

Appendages

Notes

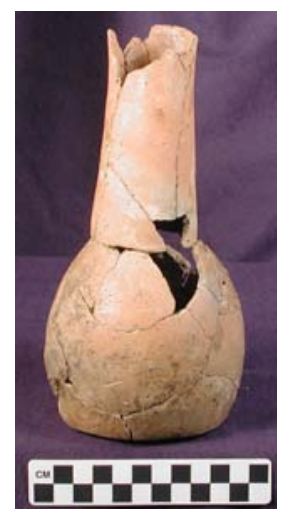

1-7, 2725

bottle

1787

Smithport Plain?

red slipped?

plain :: plain

SOFT, SILTY, COMPACT

GROG \& GRIT

LIGHT GRAY

LIGHT RED, LIGHT YELLOWISH BROWN, BROWN

LIGHT BROWN, LIGHT YELLOWISH RED

HEAVILY MENDED BOTTLE, FIRECLOUDS

GLOBULAR, TALL-NECKED BOTTLE W/ FLAT, ROUND BASE, BODY

SQUAT GLOBE, RIM SLIGHTLY FLARED

ROUNDED, DIRECT

11.2

.5

SMOOTHED \& SLIPPED

RED SLIPPED?

CARAFE, LONG NECKED

10.3

9.9

.4

SMOOTHED \& SLIPPED

RED SLIPPED?

OVOID

CIRCULAR, FLAT

9.1

Huddleston Grave D, 12/13/1942 (with 1-17), East phase; Huddleston cat. card, "Coles Creek ware" 
JEC Hodges Collection, 77-1

East Place, 3CL21

Item No./Hodges Catalog

Vessel Form

AAS/HSU Digital Photo No.

Type

Decoration

Rim :: Body

Paste

Temper

Color, Core

Color, Exterior

Color, Interior

Overall Height $\mathrm{cm}$

Weight g

Volume liters

Use/Wear/Condition

Shape / Description

Lip Treatment

Orifice Diameter cm

Rim Height cm

Rim Thickness cm

Rim Surface Treatment

Rim Decorative Treatment

Rim/Neck Shape

Body Maximum Diameter cm

Body Height cm

Body Thickness cm

Body Surface Treatment

Body Decorative Treatment

Body Shape

Base Shape

Base Diameter $\mathrm{cm}$

Base Height cm

Base Surface Treatment

Base Decorative Treatment

Appendages

Notes

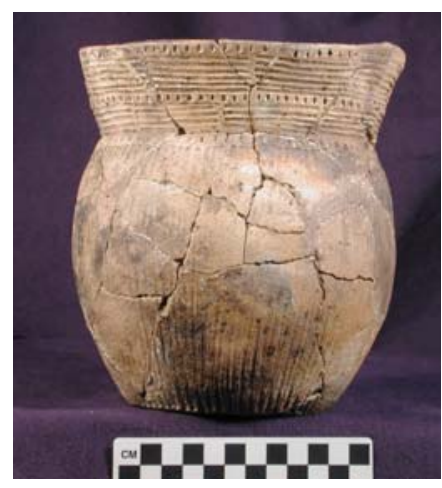

$1-8,2745$

jar, tall rim

1781

Pease Brushed-Incised or Karnack Brushed-Incised

incised/punctated

Case 8 (type) :: Claflin 8 (type)

SOFT, CRUMBLY

GROG

LIGHT GRAY

REDDISH YELLOW, GRAY, VERY PALE BROWN

DARK BROWN

\author{
BADLY BROKEN, HEAVILY MENDED \\ GLOBULAR, TALL-RIMMED JAR \\ ROUNDED, SLIGHTLY EVERTED \\ 16.1 \\ 4.3 \\ .7
}

SMOOTHED \& INCISED \& PUNCTATED

PUNCTATIONS/INCISING, FROM LIP DOWN HAS 1 ROW PUNCTATES, 6

INCISED LINES, 1ROW PUNCT, 5 INCIS LINES, DISCONTINUOUS

STRAIGHT, OUTSLANTED

15.8

13.5

.5

SMOOTHED \& INCISED \& PUNCTATED

ROW PUNCTATES AT SOULDER \& VERTICAL INCISING

SUB-GLOBULAR

CIRCULAR, FLAT

9.9

RIM TABS, 2 OPPOSABLE (RIM PEAKS?)

Huddleston Grave F, 1/1/1943 (with 1-24, 1-29, 1-43, 1-44?); previous illustration Newell \& Krieger 1949: Fig. 65L; Suhm \& Jelks 1962: Plate $60 \mathrm{G}$ 
JEC Hodges Collection, 77-1

East Place, 3CL21

Item No./Hodges Catalog

Vessel Form

AAS/HSU Digital Photo No.

Type

Decoration

Rim :: Body

Paste

Temper

Color, Core

Color, Exterior

Color, Interior

Overall Height cm

Weight g

Volume liters

Use/Wear/Condition

Shape / Description

Lip Treatment

Orifice Diameter $\mathrm{cm}$

Rim Height cm

Rim Thickness cm

Rim Surface Treatment

Rim Decorative Treatment

Rim/Neck Shape

Body Maximum Diameter cm

Body Height cm

Body Thickness cm

Body Surface Treatment

Body Decorative Treatment

Body Shape

Base Shape

Base Diameter cm

Base Height cm

Base Surface Treatment

Base Decorative Treatment Appendages

Notes

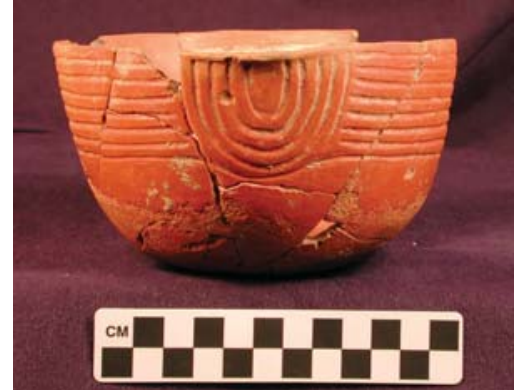

1-9, 2490

bowl, simple

1777

East Incised

red slipped/incised

Barrington 10 :: plain

SOFT, CRUMBLY

GRIT

VERY DARK GRAY

RED-SLIPPED

RED-SLIPPED

HIGH AMOUNT OF ABRASION ON BOTTOM OF VESSEL WHICH PERSISTS UP VESSEL FOR 3CM, RED SLIP HAS WORN AWAY IN PLACES. SOME ABRASION ON INSIDE OF VESSEL

BOWL WITH INCISED (TRAILED-4.28MM WIDE) RIM TABS

FLATTENED, NO ANGLE/DIRECT

15.5

8.3

.5

SMOOTHED

7 HORIZONTAL INCISED LINES ON 1/2 OF VESSEL, 8 HORIZONTAL LINES ON OTHER 1/2; 2 5-LINE INCISED FESTOONS UNDER RIM TAB, RED SLIP

STRAIGHT, OUTSLANTED

15.0

CONICAL

CIRCULAR, CONVEX

9.9

TAB HANDLES AT RIM, INCISED AREA ON TOP OF TAB Huddleston Grave X, 5/9/1941 (with 1-1, 1-5, 1-28), East phase; previous illustration Newell \& Krieger 1949: Fig. 65K; Suhm \& Jelks 1962: Plate 21A 
JEC Hodges Collection, 77-1

East Place, 3CL21

Item No./Hodges Catalog

Vessel Form

AAS/HSU Digital Photo No.

Type

Decoration

Rim :: Body

Paste

Temper

Color, Core

Color, Exterior

Color, Interior

Overall Height cm

Weight g

Volume liters

Use/Wear/Condition

Shape / Description

Lip Treatment

Orifice Diameter cm

Rim Height cm

Rim Thickness cm

Rim Surface Treatment

Rim Decorative Treatment

Rim/Neck Shape

Body Maximum Diameter $\mathrm{cm}$

Body Height cm

Body Thickness cm

Body Surface Treatment

Body Decorative Treatment

Body Shape

Base Shape

Base Diameter cm

Base Height cm

Base Surface Treatment

Base Decorative Treatment Appendages

Notes

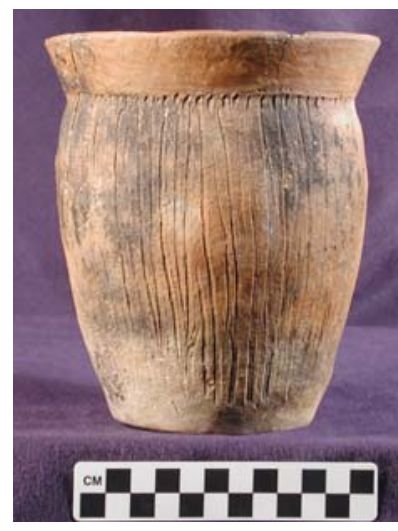

1-10

jar, short rim

1762

Karnack Brushed-Incised ?

incised

plain :: Antioch 3

HARD

GROG \& GRIT

LIGHT RED

BLACK, VERY PALE BROWN, LIGHT RED

DARK GRAY, LIGHT YELLOWISH BROWN

FIRECLOUDS

JAR W/ SHORT, FLARING RIM

ROUNDED

14.0

2.6

.5

SMOOTHED \& BURNISHED

STRAIGHT, OUTSLANTED

13.6

13.7

.5

SMOOTHED \& BURNISHED \& INCISED

VERTICAL INCISING, NOT VERY REGULAR, LINES DO NOT CONTINUE TO BASE

HIGH-WAISTED, ELONGATED

CIRCULAR, FLAT

7.9

Huddleston, 9/1942 (labeled "East Sept. 42" on base); previous illustration Suhm \& Jelks 1962: Plate 80M 
JEC Hodges Collection, 77-1

East Place, 3CL21

Item No./Hodges Catalog

Vessel Form

AAS/HSU Digital Photo No.

Type

Decoration

Rim :: Body

Paste

Temper

Color, Core

Color, Exterior

Color, Interior

Overall Height cm

Weight g

Volume liters

Use/Wear/Condition

Shape / Description

Lip Treatment

Orifice Diameter cm

Rim Height cm

Rim Thickness cm

Rim Surface Treatment

Rim Decorative Treatment

Rim/Neck Shape

Body Maximum Diameter cm

Body Height cm

Body Thickness cm

Body Surface Treatment

Body Decorative Treatment

Body Shape

Base Shape

Base Diameter cm

Base Height cm

Base Surface Treatment

Base Decorative Treatment

Appendages

Notes

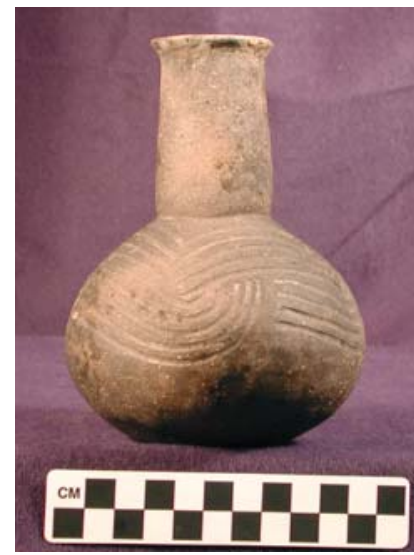

1-12, 1368 (Huddleston 200)

bottle

1791

Keno Trailed var. Red Hill

Incised/trailed

plain :: Belhaven 31 (type)

SOFT

SHELL (LEACHED)

GRAY

VERY DARK GRAY

DARK GRAY

PROBE HOLE AT SHOULDER, OVAL 3X4MM

SMALL, SQUAT GLOBULAR BOTTLE W/ CYLINDRICAL NECK, FLARED

LIP, ROUND CONCAVE BASE

ROUNDED, FLARED

4.5

6.1

.4

SMOOTHED \& BURNISHED

SPOOL

10.5

8.0

SMOOTHED \& INCISED

INCISING

SUB-GLOBULAR

CIRCULAR, CONCAVE

4.7

Huddleston Grave 1 or 2, 4/29/1939 (with 1-36, 1-48, 1-49), late Social Hill to Deceiper phase; Huddleston sketch in notebook; Phillips photo 3868 
JEC Hodges Collection, 77-1 East Place, 3CL21

\section{Item No./Hodges Catalog} Vessel Form

AAS/HSU Digital Photo No.

Type

Decoration

Rim :: Body

Paste

Temper

Color, Core

Color, Exterior

Color, Interior

Overall Height cm

Weight g

Volume liters

Use/Wear/Condition

Shape / Description

Lip Treatment

Orifice Diameter cm

Rim Height cm

Rim Thickness cm

Rim Surface Treatment

Rim Decorative Treatment

Rim/Neck Shape

Body Maximum Diameter cm

Body Height cm

Body Thickness cm

Body Surface Treatment

Body Decorative Treatment

Body Shape

Base Shape

Base Diameter $\mathrm{cm}$

Base Height cm

Base Surface Treatment

Base Decorative Treatment Appendages

Notes

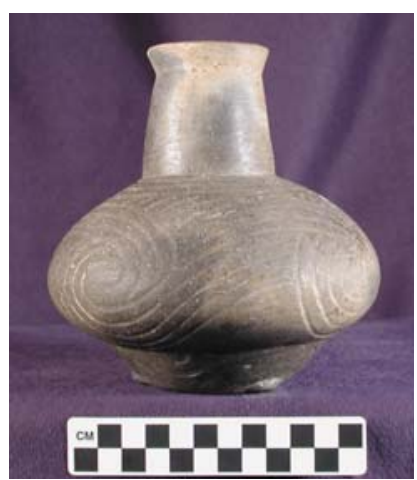

1-13, 1371 (Huddleston 207)

Bottle, pedestalled

1798

Keno Trailed

Incised/trailed

plain :: Belhaven 32 (type)

HARD, COMPACT

GROG \& GRIT

DARK GRAY FIRECLOUDS, WHITE, VERY PALE BROWN

VERY PALE BROWN

FIRE CLOUDS

SQUAT, PEDESTALLED BOTTLE WITH SHORT CYLINDRICAL NECK, FLARING RIM, 3 NODES IN PEDESTAL

FLATTENED, EVERTED

5.4

5.7

.2

SMOOTHED \& BURNISHED

SPOOL, INSLOPING

14.7

7.3

.5

SMOOTHED \& BURNISHED

TRAILING

SUB-GLOBULAR

CIRCULAR, FLAT, PEDESTAL

6.2

2.3

PEDESTAL-OUTSLANTING CYLINDRICAL WITH 3 NODES

Huddleston Grave 3, 4/29-5/5/1939 (with 1-32, 1-34, 1-41?, 1-50), late Social Hill to Deceiper phase; Huddleston sketch in notebook; Phillips photo 3858 
JEC Hodges Collection, 77-1 East Place, 3CL21

Item No./Hodges Catalog Vessel Form

AAS/HSU Digital Photo No.

Type

Decoration

Rim :: Body

Paste

Temper

Color, Core

Color, Exterior

Color, Interior

Overall Height cm

Weight g

Volume liters

Use/Wear/Condition

Shape / Description

Lip Treatment

Orifice Diameter $\mathrm{cm}$

Rim Height cm

Rim Thickness cm

Rim Surface Treatment

Rim Decorative Treatment

Rim/Neck Shape

Body Maximum Diameter cm

Body Height cm

Body Thickness cm

Body Surface Treatment

Body Decorative Treatment

Body Shape

Base Shape

Base Diameter cm

Base Height cm

Base Surface Treatment

Base Decorative Treatment Appendages

Notes

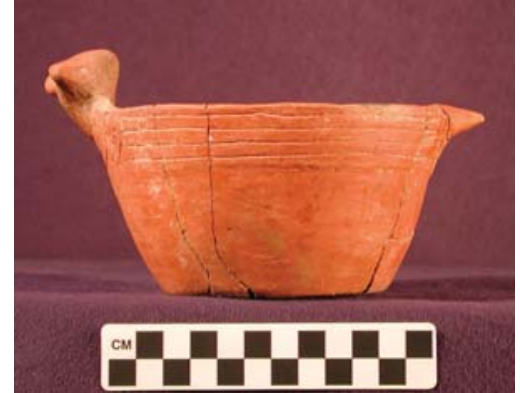

$1-14,2694$

effigy bowl

1201

East Incised

red slipped/incised/effigy

Bates 15 or Barrington 5 :: plain

SOFT, GRANULAR, COMPACT

GROG

RED (2.5YR4/8)

RED (2.5YR4/8)

7.7

326

VESSEL RECONSTRUCTED AND BADLY PLASTERED (TAIL TAB), NO

APPARENT WEAR, SLIP WORN OFF INTERIOR OF HEAD

SMALL EFFIGY VESSEL, SHALLOW BOWL WITH ANIMAL HEAD (FOX?)

RIDING ON RIM FACING UP; ABRUPT BREAK BETWEEN BASE AND

BODY

FLATTENED, DIRECT

13.9

2.6

.6

SMOOTHED \& BURNISHED \& SLIPPED

RED SLIPPED INT AND EXT AND ORANGE INCISED HORIZONTAL

LINES-PARTLY SMOOTHED OVER 4 INCISED LINES (0.1CM WIDE, .5-

.6CM APART), NO OVERHANGING-5 UNDER HEAD APPENDAGE

STRAIGHT, OUTSLANTED

11.6

4.8

6

SMOOTHED \& BURNISHED \& SLIPPED

CONICAL

CIRCULAR, FLAT; BASE RECONSTR WITH PLASTER

8.8

ANIMAL HEAD ON RIM-TAIL LUG RECONSTR WITH PLASTER

Huddleston Grave B, 11/21/1942 (with 1-2, 1-3) East phase 
JEC Hodges Collection, 77-1 East Place, 3CL21

tem No./Hodges Catalog Vessel Form

AAS/HSU Digital Photo No.

Type

Decoration

Rim :: Body

Paste

Temper

Color, Core

Color, Exterior

Color, Interior

Overall Height $\mathrm{cm}$

Weight g

Volume liters

Use/Wear/Condition

Shape / Description

Lip Treatment

Orifice Diameter $\mathrm{cm}$

Rim Height cm

Rim Thickness cm

Rim Surface Treatment

Rim Decorative Treatment

Rim/Neck Shape

Body Maximum Diameter cm

Body Height cm

Body Thickness cm

Body Surface Treatment

Body Decorative Treatment

Body Shape

Base Shape

Base Diameter cm

Base Height cm

Base Surface Treatment

Base Decorative Treatment Appendages

Notes

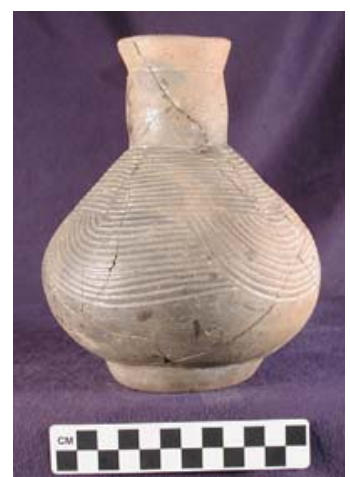

1-16, 2097 (Huddleston 245?)

Bottle, pedestalled

1817

Keno Trailed var. Red Hill

incised/trailed

plain :: Belhaven 33 (type)

SOFT, FINE, SILTY, COMPACT

SHELL (SOME LEACHED)

VERY DARK GRAYISH BROWN (10YR3/2)

REDDISH YELLOW (5YR6/6), YELLOWISH RED (5YR4/8), GRAY

(10YR5/1)

(10YR4/2)

17.9

514

NO USEWEAR APPARENT, VESSEL BROKEN,POORLY MENDED,

PLASTERED. BOTTLE IRREGULAR.

SHORT SQUAT BOTTLE WITH SHORT NECK AND FLARED RIM, PEDESTAL BASE

FLAT, EVERTED

5.8

5.4

.6

SMOOTHED \& BURNISHED

WIDE LINE (2-3MM) ENGRAVED AROUND BOTTLE NECK AT JUNCTION OF NECK AND BODY

SPOOL

14.3

10.8

.6

SMOOTHED \& BURNISHED

INCISED, VERY REGULAR LINES SPACED ABOUT 1-2MM APART

SUB-GLOBULAR

CIRCULAR, CONCAVE, PEDESTAL

8.7

1.6

Huddleston Grave 7, 8/5/1939 (with 1-33), late Social Hill to Deceiper phase 
JEC Hodges Collection, 77-1

East Place, 3CL21

Item No./Hodges Catalog

Vessel Form

AAS/HSU Digital Photo No.

Type

Decoration

Rim :: Body

Paste

Temper

Color, Core

Color, Exterior

Color, Interior

Overall Height cm

Weight g

Volume liters

Use/Wear/Condition

Shape / Description

Lip Treatment

Orifice Diameter cm

Rim Height cm

Rim Thickness cm

Rim Surface Treatment

Rim Decorative Treatment

Rim/Neck Shape

Body Maximum Diameter cm

Body Height cm

Body Thickness cm

Body Surface Treatment

Body Decorative Treatment

Body Shape

Base Shape

Base Diameter $\mathrm{cm}$

Base Height cm

Base Surface Treatment

Base Decorative Treatment

Appendages

Notes

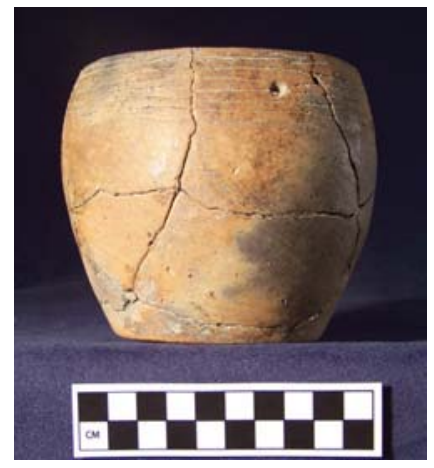

1-17, 2726

beaker

K5133

East Incised

incised

Barrington 1 :: plain

HARD, SMOOTH, COMPACT

GROG

5YR5/6, 10YR4/1, 7.5YR6/6

7.5YR5/4, 10YR6/1

11.1

376

0.775

BEAKER WITH INCISING AT RIM, 2 SUSPENSION HOLES

ROUNDED

10.7

0.43

INCISED LINES, 7 LINES 1MM THICK, 2-4MM APART, A LITTLE SLOPPY, PARTLY SMOOTHED OVER

CONVEX, INSLANTED

12.2

0.6

BURNISHED

PLAIN

OVOID

CIRCULAR, SLIGHTLY CONVEX

8

SUSPENSION HOLES 2 HOLES .3MM DRILLED FROM OUTSIDE AND INSIDE AFTER FIRING

Huddleston Grave D, 12/13/1942 (with 1-7), East phase; previous

illustration Newell \& Krieger 1949: Fig. 65D 
JEC Hodges Collection, 77-1 East Place, 3CL21

Item No./Hodges Catalog Vessel Form

AAS/HSU Digital Photo No.

Type

Decoration

Rim :: Body

Paste

Temper

Color, Core

Color, Exterior

Color, Interior

Overall Height cm

Weight g

Volume liters

Use/Wear/Condition

Shape / Description

Lip Treatment

Orifice Diameter $\mathrm{cm}$

Rim Height cm

Rim Thickness cm

Rim Surface Treatment

Rim Decorative Treatment

Rim/Neck Shape

Body Maximum Diameter cm

Body Height cm

Body Thickness cm

Body Surface Treatment

Body Decorative Treatment

Body Shape

Base Shape

Base Diameter $\mathrm{cm}$

Base Height cm

Base Surface Treatment

Base Decorative Treatment

Appendages

Notes

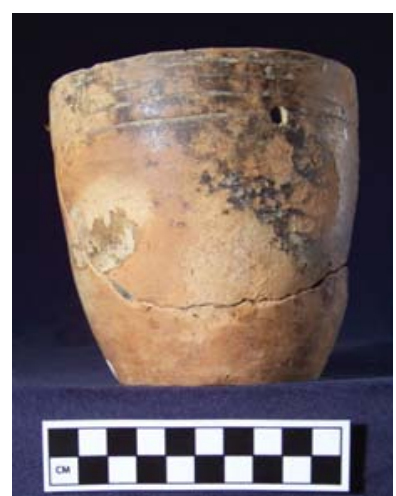

$1-18,2710$

beaker

K5165

East Incised

incised

Bates 3 :: plain

GROG

5YR5/6, 5YR4/4, 10YR6/3

11.8

438

0.7

FIRECLOUDS ON BODY

BEAKER WITH INCISED LINES AND SUSPENSION HOLES

ROUND FLATTENED

11.6

0.5

BURNISHED

INCISED LINES, 4 CONCENTRIC LINES 5-9MM APART, 1MM WIDE STRAIGHT, SLIGHTLY OUTSLANTED

11.2

0.5

BURNISHED

PLAIN

OVOID

CIRCULAR, FLAT

7.7

BURNISHED

SUSPENSION HOLES, 2, DRILLED FROM OUTSIDE, AT LEVEL OF INCISED LINES

Huddleston Grave C, 12/12/1942 (with 1-25), East phase 
JEC Hodges Collection, 77-1

East Place, 3CL21

Item No./Hodges Catalog

Vessel Form

AAS/HSU Digital Photo No.

Type

Decoration

Rim :: Body

Paste

Temper

Color, Core

Color, Exterior

Color, Interior

Overall Height cm

Weight g

Volume liters

Use/Wear/Condition

Shape / Description

Lip Treatment

Orifice Diameter $\mathrm{cm}$

Rim Height cm

Rim Thickness cm

Rim Surface Treatment

Rim Decorative Treatment

Rim/Neck Shape

Body Maximum Diameter cm

Body Height cm

Body Thickness cm

Body Surface Treatment

Body Decorative Treatment

Body Shape

Base Shape

Base Diameter cm

Base Height cm

Base Surface Treatment

Base Decorative Treatment Appendages

Notes

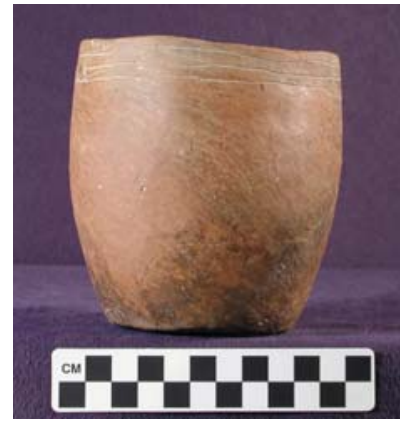

1-19, 2690

beaker

591

East Incised

red slipped/incised

Barrington 7 :: plain

GROG \& CLAYGRIT

RED, GRAY, REDDISH YELLOW

RED, GRAY, REDDISH YELLOW

FIRE CLOUDS

JAR-BEAKER

DIRECT

10.0

2.1

.7

SMOOTHED \& BURNISHED \& SLIPPED

INCISED

CONVEX, VERTICAL

10.9

10.2

.6

SMOOTHED \& BURNISHED \& SLIPPED

BARREL SHAPED

CIRCULAR, FLAT

7.5

SUSPENSION HOLES

Huddleston Grave A', 11/14/1942 (with 1-4, 1-30, 1-31, 1-46?), East phase 
JEC Hodges Collection, 77-1

East Place, 3CL21

Item No./Hodges Catalog

Vessel Form

AAS/HSU Digital Photo No.

Type

Decoration

Rim :: Body

Paste

Temper

Color, Core

Color, Exterior

Color, Interior

Overall Height cm

Weight g

Volume liters

Use/Wear/Condition

Shape / Description

Lip Treatment

Orifice Diameter cm

Rim Height cm

Rim Thickness cm

Rim Surface Treatment

Rim Decorative Treatment

Rim/Neck Shape

Body Maximum Diameter cm

Body Height cm

Body Thickness cm

Body Surface Treatment

Body Decorative Treatment

Body Shape

Base Shape

Base Diameter $\mathrm{cm}$

Base Height cm

Base Surface Treatment

Base Decorative Treatment

Appendages

Notes

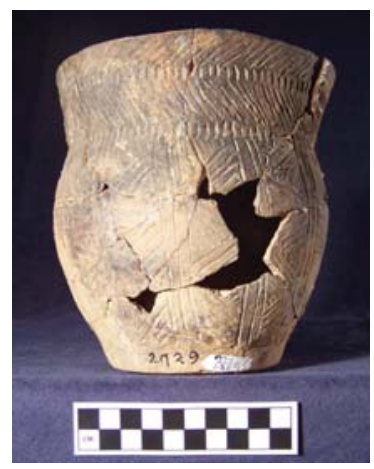

1-20, 2729

jar, tall rim

K5129

Pease Brushed-Incised

incised/punctated

Andes 10? :: Alma 3

HARD, SMOOTH, COMPACT

GROG

10YR8/4, 2.5YR6/8

5YR6/6, 5YR4/1, 7.5YR7/6

5YR6/6, 10YR4/1

17.4

767

1.8

NONE; MISSING PIECES OF RIM/LIP AND BODY

TALL RIM JAR, INCISED

ROUNDED

15.2

4.7

0.722

SMOOTHED

INCISED DIAGONAL LINES SEP. BY TOOL PUNCT.

SLIGHTLY CONCAVE, OUTSLANTED

16.6

15.2

0.756

SMOOTHED

WIDE INCISING, VERTICAL LINES SEPARATING NESTED TRIANGLES

OVOID

CIRCULAR, FLAT

9.236

SMOOTHED

Huddleston Grave E, 12/18/1942, East phase 
JEC Hodges Collection, 77-1

East Place, 3CL21

Item No./Hodges Catalog

Vessel Form

AAS/HSU Digital Photo No.

Type

Decoration

Rim :: Body

Paste

Temper

Color, Core

Color, Exterior

Color, Interior

Overall Height cm

Weight g

Volume liters

Use/Wear/Condition

Shape / Description

Lip Treatment

Orifice Diameter $\mathrm{cm}$

Rim Height cm

Rim Thickness cm

Rim Surface Treatment

Rim Decorative Treatment

Rim/Neck Shape

Body Maximum Diameter cm

Body Height cm

Body Thickness cm

Body Surface Treatment

Body Decorative Treatment

Body Shape

Base Shape

Base Diameter cm

Base Height cm

Base Surface Treatment

Base Decorative Treatment Appendages

Notes

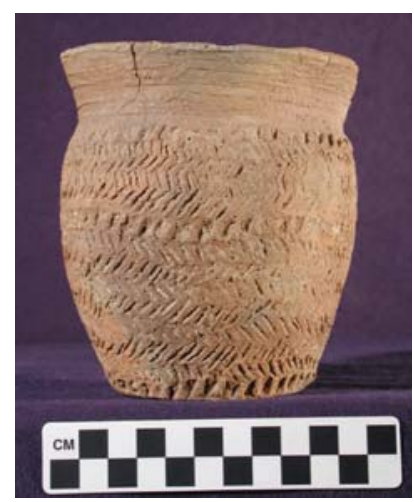

1-21, 2643

jar, short rim

1144

sim. to Military Road Incised

brushed/incised/punctated

Dana 4 :: Altus 4

MEDIUM-HARD, COARSE, CRUMBLY

GROG

5YR5/1, 5YR6/1

$5 Y R 5 / 4,5 Y R 4 / 3,5 Y R 4 / 1$

5YR6/6, 5YR5/6, 5YR6/2

12.9

352

NONE APPARENT, VESSEL INTACT EXCEPT FOR BROKEN RIM-ABOUT

HALF OF RIM MISSING WITH 2 SHERDS GLUED IN

SHORT RIM JAR, INCISED/PUNCTATED DECORATION

FLATTENED, SLIGHTLY BEVELED, SLIGHTLY EVERTED

11.0

2.9

.4

BRUSHED

STRAIGHT, OUTSLANTED

11.4

10

.5

SMOOTHED \& BURNISHED (INTERIOR)

BODY COVERED WITH INCISING (SHORT HERRINGBONE DESIGN) AND

PUNCTATIONS IN 3 LINES (LOOKS LIKE SQUARISH RATHER THAN 'C'-

ISH)

HIGH-WAISTED, ELONGATED

CIRCULAR, FLAT

7.0

Related to Sinner Linear Punctated? Huddleston Grave XX, 9/19/1942 (with 1-22), East to Mid-Ouachita phase 
JEC Hodges Collection, 77-1

East Place, 3CL21

Item No./Hodges Catalog

Vessel Form

AAS/HSU Digital Photo No.

Type

Decoration

Rim :: Body

Paste

Temper

Color, Core

Color, Exterior

Color, Interior

Overall Height cm

Weight g

Volume liters

Use/Wear/Condition

Shape / Description

Lip Treatment

Orifice Diameter $\mathrm{cm}$

Rim Height cm

Rim Thickness cm

Rim Surface Treatment

Rim Decorative Treatment

Rim/Neck Shape

Body Maximum Diameter cm

Body Height cm

Body Thickness cm

Body Surface Treatment

Body Decorative Treatment

Body Shape

Base Shape

Base Diameter $\mathrm{cm}$

Base Height cm

Base Surface Treatment

Base Decorative Treatment

Appendages

Notes

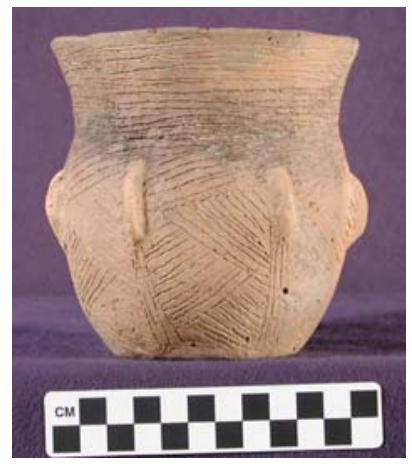

1-22, 2642

jar, tall rim

1167

Pease Brushed-Incised?

incised/applique

Butler 1 :: Alma 3?

MEDIUM-HARD, COMPACT

GROG

5YR6/4, 5YR6/2, 5YR5/6

5YR5/3, 5YR5/6, SOOTING

12.4

388

SOOTING ON VESSEL INTERIOR, INSIDE LIP, TRACE ON EXTERIOR

AROUND SHOULDER. CHIP OFF RIM

SMALL TALL RIM JAR - FLAT BOTTOMED, SUBGLOBULAR BODY -

FLARED RIM - INCISED AND NODED DECORATION

ROUNDED, SLIGHTLY EVERTED

12.3

3.9

.5

SMOOTHED

INCISED DECORATION - MULTIPLE HORIZONTAL LINES (13-14 LINES),

LINES <.1 WIDE - 2-3MM APART

STRAIGHT, OUTSLANTED

11.5

8.3

4

SMOOTHED

INCISED DECORATION-MULTIPLE INCISED LINES FORM DIAGONAL

PATTERNS - SEPARATED INTO PANELS WITH NODES AND VERTICAL

LINES (3-4)

SUBGLOBULAR, MAX DIA. 1/3 WAY FROM TOP OF BODY

CIRCULAR, FLAT

7.3

7 ELONGATED NODES APPLIQUED AROUND BODY AT MAX BODY DIAM. - NOT HANDLES OR TABS

Huddleston Grave XX, 9/19/1942 (with 1-21), East to Mid-Ouachita

phase; previous illustration Newell \& Krieger 1949: Fig. 65M 
JEC Hodges Collection, 77-1

East Place, 3CL21

Item No./Hodges Catalog

Vessel Form

AAS/HSU Digital Photo No.

Type

Decoration

Rim :: Body

Paste

Temper

Color, Core

Color, Exterior

Color, Interior

Overall Height cm

Weight g

Volume liters

Use/Wear/Condition

Shape / Description

Lip Treatment

Orifice Diameter $\mathrm{cm}$

Rim Height cm

Rim Thickness cm

Rim Surface Treatment

Rim Decorative Treatment

Rim/Neck Shape

Body Maximum Diameter cm

Body Height cm

Body Thickness cm

Body Surface Treatment

Body Decorative Treatment

Body Shape

Base Shape

Base Diameter cm

Base Height cm

Base Surface Treatment

Base Decorative Treatment

Appendages

Notes

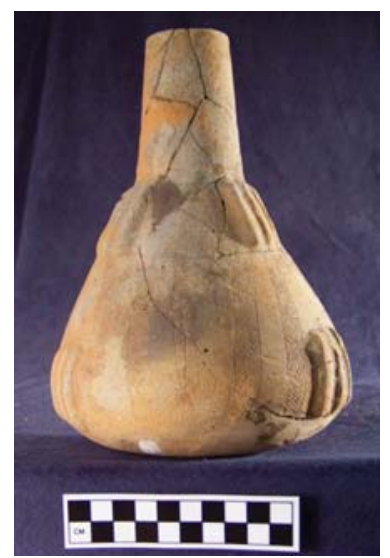

1-23, 2512

bottle

K5141

Adair Engraved

engraved/appliqued

Eagle 3 :: Eric 1

SOFT, SMOOTH, COMPACT

GROG

5YR5/6, 7.5YR5/2, 7.5YR3/1

22.4

640

1.4

NONE; SURFACE IS ERODED AND WORN

BOTTLE, ENGRAVED AND APPLIQUE

ROUNDED, SMOOTHED

4.3

7.7

0.52

ERODED

INCISED LINE AT JUNCTION OF NECK \& BODY

INSLOPING

14.5

14.9

ERODED

CONCENTRIC ENGR LINES, CROSSHATCHED, VERTICAL IRREGULAR

APPLIQUES

LOW-WAISTED

CIRCULAR

13

ERODED

VERTICAL APPLIQUED STRIPS ON BODY

Huddleston Grave X or Y, 12/6/1941 (with 1-47), Mid-Ouachita phase 
JEC Hodges Collection, 77-1

East Place, 3CL21

Item No./Hodges Catalog

Vessel Form

AAS/HSU Digital Photo No.

Type

Decoration

Rim :: Body

Paste

Temper

Color, Core

Color, Exterior

Color, Interior

Overall Height cm

Weight g

Volume liters

Use/Wear/Condition

Shape / Description

Lip Treatment

Orifice Diameter $\mathrm{cm}$

Rim Height cm

Rim Thickness cm

Rim Surface Treatment

Rim Decorative Treatment

Rim/Neck Shape

Body Maximum Diameter cm

Body Height cm

Body Thickness cm

Body Surface Treatment

Body Decorative Treatment

Body Shape

Base Shape

Base Diameter cm

Base Height cm

Base Surface Treatment

Base Decorative Treatment

Appendages

Notes

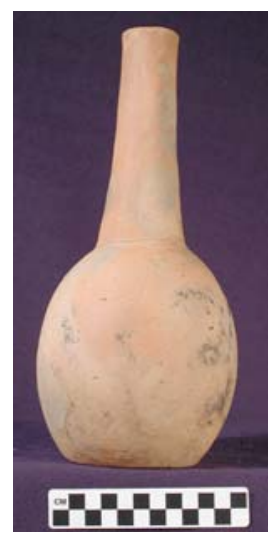

1-24, 2742

bottle

1408

Smithport Plain

plain

plain :: plain

GRANULAR, GRITTY

GROG \& CLAYGRIT

REDDISH YELLOW, BLACK FIRECLOUDS

29.9

710

FIRECLOUDS, BLACK RESIDUE ON BODY EXTERIOR

TALL, GLOBULAR BOTTLE WITH VERY TALL NECK. FLAT, CIRCULAR

BASE

ROUNDED

4.0

15.2

.3

SMOOTHED \& SLIPPED

INSLOPING, LONG NECKED

13.4

14.7

SMOOTHED \& SLIPPED

BARREL SHAPED

CIRCULAR, FLAT

8.5

Huddleston Grave F, 1/1/1943 (with 1-8, 1-29, 1-43, 1-44?), East phase 
JEC Hodges Collection, 77-1

East Place, 3CL21

Item No./Hodges Catalog

Vessel Form

AAS/HSU Digital Photo No.

Type

Decoration

Rim :: Body

Paste

Temper

Color, Core

Color, Exterior

Color, Interior

Overall Height cm

Weight g

Volume liters

Use/Wear/Condition

Shape / Description

Lip Treatment

Orifice Diameter cm

Rim Height cm

Rim Thickness cm

Rim Surface Treatment

Rim Decorative Treatment

Rim/Neck Shape

Body Maximum Diameter cm

Body Height cm

Body Thickness cm

Body Surface Treatment

Body Decorative Treatment

Body Shape

Base Shape

Base Diameter cm

Base Height cm

Base Surface Treatment

Base Decorative Treatment

Appendages

Notes

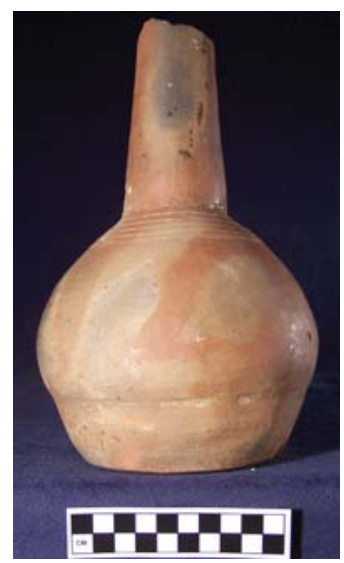

1-25, 2708

bottle

K5150

sim. to Hickory Fine Engraved

Incised (dry paste)

Bates 9 :: plain

HARD, SMOOTH, COMPACT

GROG

$7.5 \mathrm{YR} 5 / 3$

5YR4/6, 7.5YR5/2, 7.5YR3/1

25.5

890

1.3

FIRECLOUDING ON BODY \& NECK; SCUFFING ON SIDE AND BOTTOM

INCISED BOTTLE PEDESTAL BASE

11

0.455

BURNISHED

INSLOPING

15.5

10.5

BURNISHED

INCISED, 6 CONCENTRIC LINES BELOW NECK, 1MM WIDE, 5MM APART,

DRY PASTE INCISIING

SUBGLOBULAR

CIRCULAR, FLAT, PEDESTAL

11

4

Huddleston Grave C, 12/12/1942 (with 1-18), East phase 
JEC Hodges Collection, 77-1 East Place, 3CL21

Item No./Hodges Catalog Vessel Form

AAS/HSU Digital Photo No.

Type

Decoration

Rim :: Body

Paste

Temper

Color, Core

Color, Exterior

Color, Interior

Overall Height cm

Weight g

Volume liters

Use/Wear/Condition

Shape / Description

Lip Treatment

Orifice Diameter cm

Rim Height cm

Rim Thickness cm

Rim Surface Treatment

Rim Decorative Treatment

Rim/Neck Shape

Body Maximum Diameter cm

Body Height cm

Body Thickness cm

Body Surface Treatment

Body Decorative Treatment

Body Shape

Base Shape

Base Diameter cm

Base Height cm

Base Surface Treatment

Base Decorative Treatment Appendages

Notes

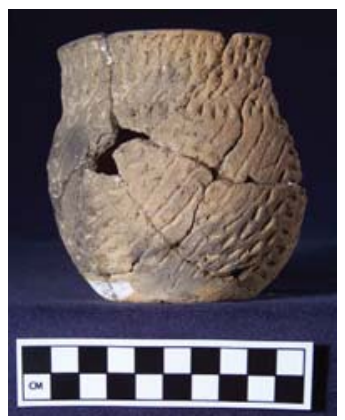

$1-28,2493$

jar, short rim

K5159

incised/punctated

Caldwell 3 ? :: Claflin new

HARD, SMOOTH, COMPACT

GROG

10YR6/2, 7.5YR4/2

2.5YR6/6, 7.5YR6/4, 10YR6/1

5YR6/6, 10YR6/2

9.9

246

0.3

NONE; MISSING MOST OF RIM/LIP, PART OF BODY

JAR, SHORT RIM, INCISED \& PUNCTATED

FLATTENED, SLIGHTLY EVERTED

9.6

2.4

0.535

SMOOTHED

2-3 ROW OF PUNCTATES UNDER LIP, ROW OF CURVED LINES

EXTENDING TO BODY

STRAIGHT, SLIGHTLY OUTSLANTED

10.5

8

0.582

SMOOTHED, ERODED

INCISED, PUNCTATED, INCISED SECTIONS FRAMED BY PUNCT DESIGN

HIGH WAISTED

CIRCULAR, FLAT

6.2

SMOOTHED, ERODED

Related to Sinner Linear-Punctated?; Huddleston Grave X, 5/9/1941

(with 1-1, 1-5, 1-9), East phase 
JEC Hodges Collection, 77-1

East Place, 3CL21

Item No./Hodges Catalog

Vessel Form

AAS/HSU Digital Photo No.

Type

Decoration

Rim :: Body

Paste

Temper

Color, Core

Color, Exterior

Color, Interior

Overall Height cm

Weight g

Volume liters

Use/Wear/Condition

Shape / Description

Lip Treatment

Orifice Diameter $\mathrm{cm}$

Rim Height $\mathrm{cm}$

Rim Thickness cm

Rim Surface Treatment

Rim Decorative Treatment

Rim/Neck Shape

Body Maximum Diameter cm

Body Height cm

Body Thickness cm

Body Surface Treatment

Body Decorative Treatment

Body Shape

Base Shape

Base Diameter cm

Base Height cm

Base Surface Treatment

Base Decorative Treatment

Appendages

Notes

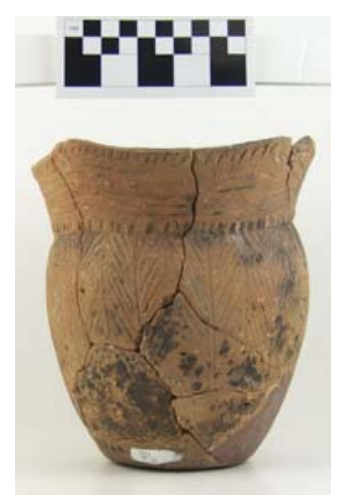

1-29, 2744

jar, tall rim

K8188

Pease Brushed-Incised

incised

Beloit 1 :: Alpha 2

HARD, SMOOTH, COMPACT

GROG

5YR5/8, 5YR7/4, 5YR6/3

$7.5 \mathrm{YR} 3 / 1$

19.5

989

2.1

WEAR ON BOTTOM; CARBONIZED ON INTERIOR (SPOTTY BLACK RESIDUE ON BASE \& EXT) PUBL SUHM \& JELKS 1962 PLATE 60E

JAR, TALL RIM, INCISED

BEVELED EXT

17.5

6

0.4

SMOOTHED

4 RIM PEAKS, ROW OF PUNCTATES, 5-6 HORIZ INCISED LINES, ROW

VERT PUNCT

STRAIGHT, OUTSLANTED

15

13.5

0.7

SMOOTHED

INCISED, VERT INCISED LINES DIVIDE CHEVRONS

HIGH-WAISTED

CIRCULAR, FLAT

9

Huddleston Grave F, 1/1/1943 (with 1-8, 1-24, 1-43, 1-44?), East phase; previous illustration Newell \& Krieger 1949: Fig. 65N; Suhm \& Jelks 1962: Plate 60E 
JEC Hodges Collection, 77-1 East Place, 3CL21

Item No./Hodges Catalog

Vessel Form

AAS/HSU Digital Photo No.

Type

Decoration

Rim :: Body

Paste

Temper

Color, Core

Color, Exterior

Color, Interior

Overall Height $\mathrm{cm}$

Weight g

Volume liters

Use/Wear/Condition

Shape / Description

Lip Treatment

Orifice Diameter cm

Rim Height cm

Rim Thickness cm

Rim Surface Treatment

Rim Decorative Treatment

Rim/Neck Shape

Body Maximum Diameter $\mathrm{cm}$

Body Height cm

Body Thickness cm

Body Surface Treatment

Body Decorative Treatment

Body Shape

Base Shape

Base Diameter $\mathrm{cm}$

Base Height cm

Base Surface Treatment

Base Decorative Treatment

Appendages

Notes

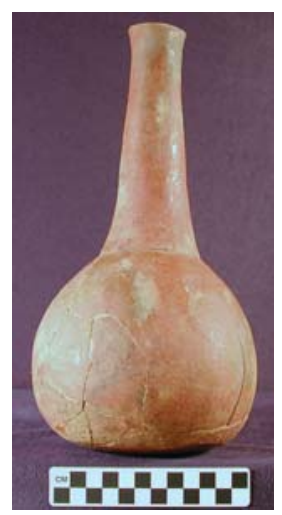

1-30, 2688

bottle

587

Smithport Plain

red slipped

plain :: plain

HARD, GRITTY, COMPACT

GROG \& CLAYGRIT

RED

FIRE CLOUDS

BOTTLE-GLOBULAR BODY AND LONG NECK; FLAT BASE

DIRECT

4.0

16.2

.4

SMOOTHED \& SLIPPED

INSLOPING, LONG NECK

14.9

12.7

SMOOTHED \& SLIPPED

GLOBULAR

CIRCULAR, FLAT

11.2

Huddleston Grave A', 11/14/1942 (with 1-4, 1-19, 1-31, 1-46?), East phase 
JEC Hodges Collection, 77-1

East Place, 3CL21

Item No./Hodges Catalog

Vessel Form

AAS/HSU Digital Photo No.

Type

Decoration

Rim :: Body

Paste

Temper

Color, Core

Color, Exterior

Color, Interior

Overall Height cm

Weight g

Volume liters

Use/Wear/Condition

Shape / Description

Lip Treatment

Orifice Diameter cm

Rim Height cm

Rim Thickness cm

Rim Surface Treatment

Rim Decorative Treatment

Rim/Neck Shape

Body Maximum Diameter cm

Body Height cm

Body Thickness cm

Body Surface Treatment

Body Decorative Treatment

Body Shape

Base Shape

Base Diameter cm

Base Height cm

Base Surface Treatment

Base Decorative Treatment

Appendages

Notes

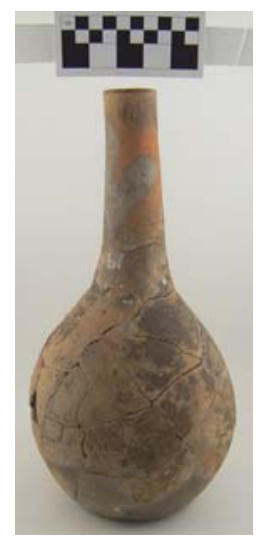

1-31, 2692

bottle

K8168

Hickory Fine Engraved

engraved

plain :: Erie 13

HARD, SMOOTH, COMPACT

GROG \& BONE

7.5YR7/6, 7.5YR8/3

34.5

904

FIRE CLOUDS ON NECK; MISSING SHERD ON NECK AND BODY, PATCHED

BOTTLE, LONG NECKED

FLAT

4

16

0.5

SMOOTHED

INSLOPING, LONG NECKED

17

18.5

SMOOTHED

5 ENGRAVED LINES UPPER BODY, THIN LINES 6MM APART

LOW WAISTED

CIRCULAR FLAT

9.5

SMOOTHED

Huddleston Grave A', 11/14/1942 (with 1-4, 1-19, 1-30, 1-46?), East phase 
JEC Hodges Collection, 77-1

East Place, 3CL21

Item No./Hodges Catalog

Vessel Form

AAS/HSU Digital Photo No.

Type

Decoration

Rim :: Body

Paste

Temper

Color, Core

Color, Exterior

Color, Interior

Overall Height cm

Weight g

Volume liters

Use/Wear/Condition

Shape / Description

Lip Treatment

Orifice Diameter cm

Rim Height cm

Rim Thickness cm

Rim Surface Treatment

Rim Decorative Treatment

Rim/Neck Shape

Body Maximum Diameter cm

Body Height cm

Body Thickness cm

Body Surface Treatment

Body Decorative Treatment

Body Shape

Base Shape

Base Diameter $\mathrm{cm}$

Base Height cm

Base Surface Treatment

Base Decorative Treatment

Appendages

Notes

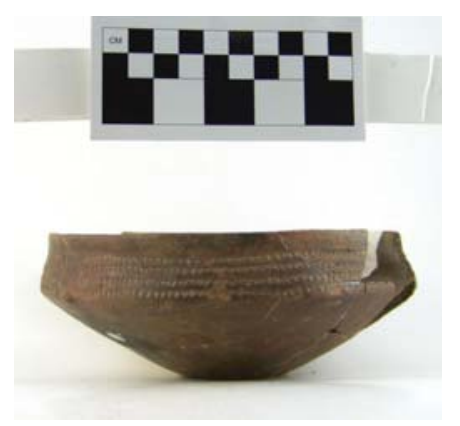

1-32, 1379 (Huddleston 204)

bowl, carinated

K8264

Means Engraved

engraved

Enos 15? 16 ? :: plain

HARD, SMOOTH, COMPACT

GROG \& SHELL (LEACHED)

$10 \mathrm{YR} 4 / 1$

10YR3/1, 10YR4/2, 7.5YR4/3

10YR4/2, 10YR2/1

7

234

FIRECLOUDING;PARTIAL, MISSING LG PIECES OF LIP, RIM, BODY

CARINATED BOWL

FLATTENED, SLIGHTLY EVERTED

17.3

3

0.5

BURNISHED

ENGRAVED, ALTERNATING PATTERN WITH TICKED LINES, NODES

STRAIGHT, INSLANTED

18

4

0.4

BURNISHED

CONICAL

CIRCULAR, SLIGHTLY CONCAVE

5

BURNISHED

2 SMALL NODES AT BASE OF RIM

Huddleston Grave 3, 4/29-5/5/1939 (with 1-13, 1-34, 1-41?, 1-50), late

Social Hill to Deceiper phase; Phillips photo 3927 
JEC Hodges Collection, 77-1

East Place, 3CL21

Item No./Hodges Catalog Vessel Form

AAS/HSU Digital Photo No.

Type

Decoration

Rim :: Body

Paste

Temper

Color, Core

Color, Exterior

Color, Interior

Overall Height cm

Weight g

Volume liters

Use/Wear/Condition

Shape / Description

Lip Treatment

Orifice Diameter $\mathrm{cm}$

Rim Height $\mathrm{cm}$

Rim Thickness cm

Rim Surface Treatment

Rim Decorative Treatment

Rim/Neck Shape

Body Maximum Diameter cm

Body Height cm

Body Thickness cm

Body Surface Treatment

Body Decorative Treatment

Body Shape

Base Shape

Base Diameter cm

Base Height cm

Base Surface Treatment

Base Decorative Treatment Appendages

Notes

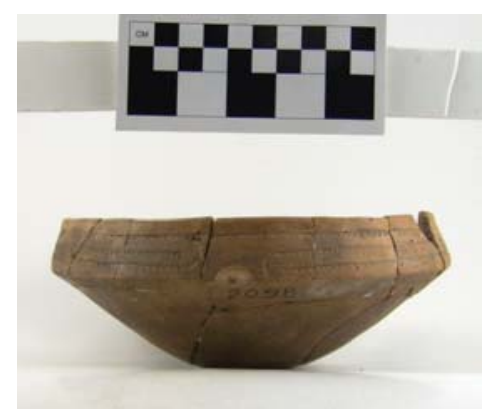

1-33, 2098 (Huddleston 244)

bowl, carinated

K8269

Means Engraved

engraved

Enos 14 :: plain

HARD, SMOOTH, COMPACT

SHELL (LEACHED) \& GROG

7.5YR4/1

5YR7/6, 5YR4/1, 7.5YR6/4

7.5YR7/3, 7.5YR4/1

7.2

256

A LITTLE FIRECLOUDING; PART OF BASE \& RIM MISSING

CARINATED BOWL

ROUNDED, SLIGHTLY EVERTED

17.4

2.4

0.5

BURNISHED

ENGRAVED; 3 TICKED LINES, HORIZ, REPEATS 2X

STRAIGHT, INSLANTED

18.8

4.8

0.6

BURNISHED

CONICAL

CIRCULAR, FLAT

4.5

BURNISHED

2 NODES AT RIM/BODY JUNCTURE WITH 'SUNRISE' DEC ABOVE Huddleston Grave 7, 8/5/1939 (with 1-16), late Social Hill to Deceiper phase 
JEC Hodges Collection, 77-1

East Place, 3CL21

Item No./Hodges Catalog

Vessel Form

AAS/HSU Digital Photo No.

Type

Decoration

Rim :: Body

Paste

Temper

Color, Core

Color, Exterior

Color, Interior

Overall Height $\mathrm{cm}$

Weight g

Volume liters

Use/Wear/Condition

Shape / Description

Lip Treatment

Orifice Diameter $\mathrm{cm}$

Rim Height cm

Rim Thickness cm

Rim Surface Treatment

Rim Decorative Treatment

Rim/Neck Shape

Body Maximum Diameter cm

Body Height cm

Body Thickness cm

Body Surface Treatment

Body Decorative Treatment

Body Shape

Base Shape

Base Diameter cm

Base Height cm

Base Surface Treatment

Base Decorative Treatment Appendages

Notes

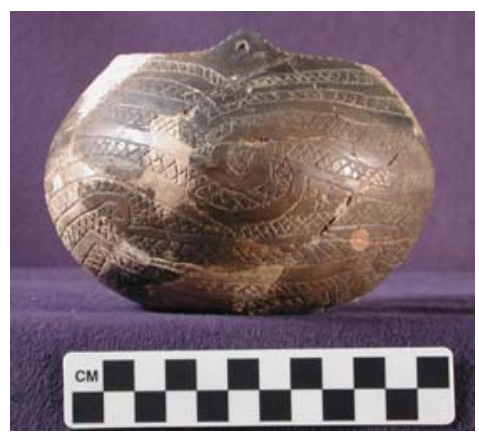

1-34, 1373 (Huddleston 202)

bowl

1348

Maddox Engraved

engraved/notched lip/slipped?

Cornell :: Elmira? Erasmus?

HARD, COMPACT

NONE VISIBLE

BLACK, BROWN, REDDISH BROWN

YELLOWISH BROWN

9.0

270

SQUAT, GLOBULAR BOWL WITH SUSPENSION HOLE TABS ON RIM, POORLY DEFINED FLAT BASE

INCURVED, PUNCTATED

8.9

CONVEX, INSLANTED

13.3

8.6

.4

SMOOTHED \& SLIPPED \& BURNISHED

ENGRAVING

SUB-GLOBULAR

CIRCULAR, FLAT

4.3

2 OPPOSING RIM TABS WITH SUSPENSION HOLES

Huddleston Grave 3, 4/29-5/5/1939 (with 1-13, 1-32, 1-41?, 1-50), late Social Hill to Deceiper phase; Phillips photo 3869 
JEC Hodges Collection, 77-1

East Place, 3CL21

Item No./Hodges Catalog Vessel Form

AAS/HSU Digital Photo No.

Type

Decoration

Rim :: Body

Paste

Temper

Color, Core

Color, Exterior

Color, Interior

Overall Height cm

Weight g

Volume liters

Use/Wear/Condition

Shape / Description

Lip Treatment

Orifice Diameter cm

Rim Height cm

Rim Thickness cm

Rim Surface Treatment

Rim Decorative Treatment

Rim/Neck Shape

Body Maximum Diameter cm

Body Height cm

Body Thickness cm

Body Surface Treatment

Body Decorative Treatment

Body Shape

Base Shape

Base Diameter $\mathrm{cm}$

Base Height cm

Base Surface Treatment

Base Decorative Treatment

Appendages

Notes

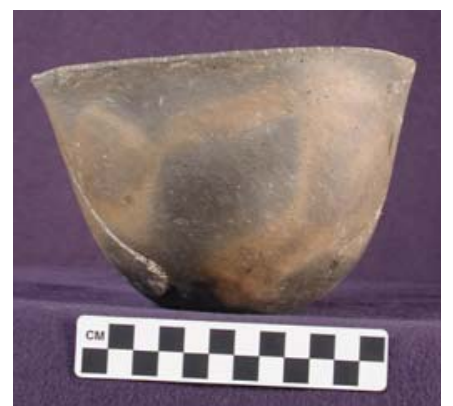

1-35, 1388 (Huddleston 226?)

bowl, simple

1113

notched lip

Cornell :: plain

HARD, FINE, COMPACT

GROG

10YR3/2, 10YR2/1, 10YR4/3

10.7

474

SOME SCRATCHES ON INSIDE ON LOWER EDGES, RIM IS A LITTLE ERODED. HAS REMNANTS OF OLD RED TAG ON INSIDE VESSEL IN 3 PIECES AND HAD BEEN GLUED TOGETHER

OPEN BOWL-SEMIROUNDED BASE- FLARED WALLS-SLIGHTLY OUTFLARED RIM

ROUNDED, SLIGHTLY EVERTED, NOTCHING ON LIP, 3-7MM APART

16.7

.5

STRAIGHT, OUTSLANTED

16.7

10.7

.5

SMOOTHED \& BURNISHED

PLAIN

CONICAL

UNDISTINGUISHED, CONVEX

sim. To Hardman Engraved in shape, lip notching; Huddleston Grave 4, 5/27/1939 (with 1-38, 1-39, 1-42), late Mid-Ouachita to Social Hill phase 
JEC Hodges Collection, 77-1 East Place, 3CL21

Item No./Hodges Catalog Vessel Form

AAS/HSU Digital Photo No.

Type

Decoration

Rim :: Body

Paste

Temper

Color, Core

Color, Exterior

Color, Interior

Overall Height $\mathrm{cm}$

Weight g

Volume liters

Use/Wear/Condition

Shape / Description

Lip Treatment

Orifice Diameter cm

Rim Height cm

Rim Thickness cm

Rim Surface Treatment

Rim Decorative Treatment

Rim/Neck Shape

Body Maximum Diameter cm

Body Height cm

Body Thickness cm

Body Surface Treatment

Body Decorative Treatment

Body Shape

Base Shape

Base Diameter cm

Base Height cm

Base Surface Treatment

Base Decorative Treatment Appendages

Notes

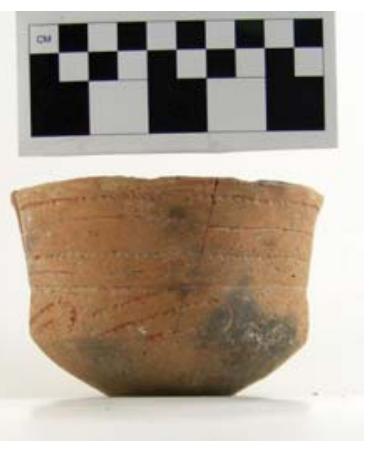

1-36, 1376 (Huddleston 199)

bowl, carinated, tall rim

K8437

Means Engraved?

engraved

Elgin 12 :: Enos new

HARD, SMOOTH, COMPACT

GROG \& SHELL (LEACHED)

5YR5/2, 5YR3/1, 5YR6/4

5YR6/4, 5YR3/1

7.8

142

0.4

SOME INT/EXT PITTING, PROB POST-DEP; 1/4 OF RIM MISSING,

RECONST W RED PLASTER

CARINATED BOWL W TALL RIM

ROUNDED, THINNED

12

3.8

0.3

BURNISHED

ENGRAVED, 4 HORIZ LINES, TICKED \& PLAIN

STRAIGHT, OUTSLANTED

10.2

4

0.4

BURNISHED

ENGRAVED, DIAGONAL TICKED LIINES ON UPPER BODY, RED PIGMENT

IN LINES

COMPOUND, CONICAL/CYLINDRICAL

CIRCULAR, FLAT

4.5

BURNISHED

Huddleston Grave 1 or 2, 4/29/1939 (with 1-12, 1-48, 1-49), late Social Hill to Deceiper phase, Phillips photo 3870 
JEC Hodges Collection, 77-1

East Place, 3CL21

Item No./Hodges Catalog

Vessel Form

AAS/HSU Digital Photo No.

Type

Decoration

Rim :: Body

Paste

Temper

Color, Core

Color, Exterior

Color, Interior

Overall Height cm

Weight g

Volume liters

Use/Wear/Condition

Shape / Description

Lip Treatment

Orifice Diameter $\mathrm{cm}$

Rim Height cm

Rim Thickness cm

Rim Surface Treatment

Rim Decorative Treatment

Rim/Neck Shape

Body Maximum Diameter cm

Body Height cm

Body Thickness cm

Body Surface Treatment

Body Decorative Treatment

Body Shape

Base Shape

Base Diameter cm

Base Height cm

Base Surface Treatment

Base Decorative Treatment

Appendages

Notes

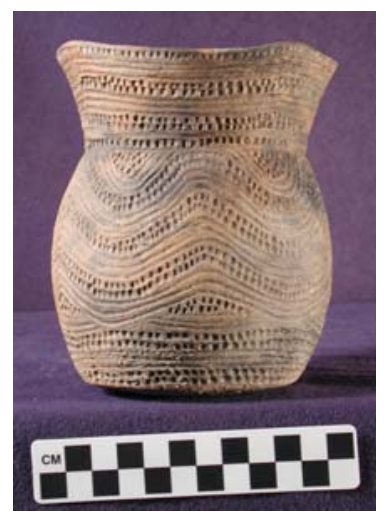

1-37, 2756

jar, short rim

1345

Military Road Incised (early variant?)

incised/punctated

Beloit 2 (type) :: Clinton 12 (type), Bard 2?

GROG \& CLAYGRIT

REDDISH YELLOW, RED, LIGHT RED

DARK GRAY, RED

14.4

476

FIRE CLOUD

JAR; GLOBULAR BODY; ROUNDED BASE; FLARED RIM; SLIGHTLY

CASTELATED RIM

CASTELATED

11.7

4.1

.6

SMOOTHED

PUNCTATED, INCISED

STRAIGHT, OUTSLANTED

11.3

9.7

.5

SMOOTHED

PUNCTATED, INCISED

SUB-GLOBULAR

CIRCULAR, FLAT

8.7

Huddleston Grave G, 1/16/1943 (with 1-6), East to Mid-Ouachita phase 
JEC Hodges Collection, 77-1 East Place, 3CL21

Item No./Hodges Catalog Vessel Form

AAS/HSU Digital Photo No.

Type

Decoration

Rim :: Body

Paste

Temper

Color, Core

Color, Exterior

Color, Interior

Overall Height $\mathrm{cm}$

Weight g

Volume liters

Use/Wear/Condition

Shape / Description

Lip Treatment

Orifice Diameter $\mathrm{cm}$

Rim Height cm

Rim Thickness cm

Rim Surface Treatment

Rim Decorative Treatment

Rim/Neck Shape

Body Maximum Diameter cm

Body Height cm

Body Thickness $\mathrm{cm}$

Body Surface Treatment

Body Decorative Treatment

Body Shape

Base Shape

Base Diameter cm

Base Height cm

Base Surface Treatment

Base Decorative Treatment Appendages

Notes

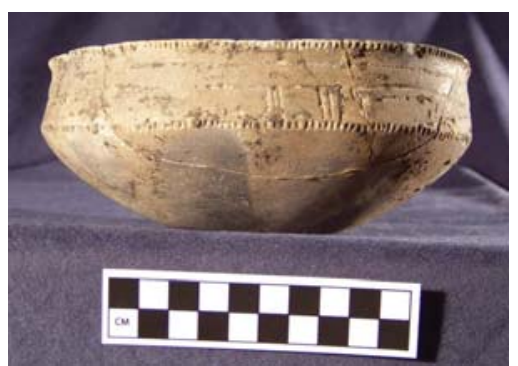

1-38, 1387 (Huddleston 229?)

bowl, carinated

K5280

Glassell Engraved ?

engraved/punctated

Enos 10? 11? 12? :: plain

SOFT, SMOOTH, COMPACT

SHELL (LEACHED) \& GROG

7.5YR5/1

7.5YR2.5/1, 7.5YR6/1, 7.5YR5/1

7.5YR5/1

6.6

266

1

SOME WEAR ON BASE; SECTION OF RIM/NECK MISSING

CONICAL-CARINATED BOWL

ROUNDED, EVERTED

17.4

3

0.6

BURNISHED

PUNCTATES AND ENGRAVED CONC LINES

STRAIGHT, INSLANTED

17.6

3.6

0.4

BURNISHED

CONVEX

CIRCULAR, FLAT

6

BURNISHED

Huddleston Grave 4, 5/27/1939 (with 1-35, 1-39, 1-42), late MidOuachita to Social Hill phase 
JEC Hodges Collection, 77-1

East Place, 3CL21

Item No./Hodges Catalog Vessel Form

AAS/HSU Digital Photo No.

Type

Decoration

Rim :: Body

Paste

Temper

Color, Core

Color, Exterior

Color, Interior

Overall Height cm

Weight g

Volume liters

Use/Wear/Condition

Shape / Description

Lip Treatment

Orifice Diameter $\mathrm{cm}$

Rim Height cm

Rim Thickness cm

Rim Surface Treatment

Rim Decorative Treatment

Rim/Neck Shape

Body Maximum Diameter cm

Body Height cm

Body Thickness cm

Body Surface Treatment

Body Decorative Treatment

Body Shape

Base Shape

Base Diameter cm

Base Height cm

Base Surface Treatment

Base Decorative Treatment

Appendages

Notes

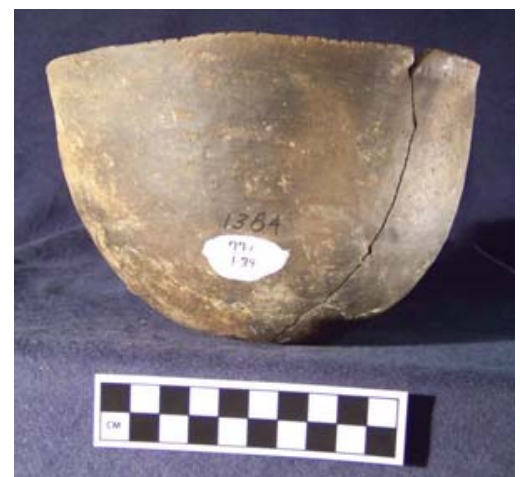

1-39, 1384 (Huddleston 227?)

bowl, simple

K5329

notched lip

Cornell 7 :: plain

HARD, SMOOTH, COMPACT

GROG \& SHELL (LEACHED)

5YR2.5/1

5YR5/4, 5YR3/1

5YR3/1

11

334

NONE SEEN; ABOUT 2/3 OF VESSEL MISSING

BOWL, SIMPLE

ROUNDED, PUNCTATED/NOTCHED ON TOP OF LIP

20

11

0.52

BURNISHED

STRAIGHT, OUTSLANTED

20

0.7

BURNISHED

CONICAL

UNDISTINGUISHED, FLAT

6

BURNISHED

Huddleston Grave 4, 5/27/1939 (with 1-35, 1-38, 1-42), late MidOuachita to Social Hill phase 
JEC Hodges Collection, 77-1

East Place, 3CL21

Item No./Hodges Catalog
Vessel Form
AAS/HSU Digital Photo No.
Type
Decoration
Rim :: Body
Paste
Temper
Color, Core
Color, Exterior
Color, Interior
Overall Height cm
Weight g
Volume liters
Use/Wear/Condition
Shape / Description
Lip Treatment
Orifice Diameter cm
Rim Height cm
Rim Thickness cm
Rim Surface Treatment
Rim Decorative Treatment
Rim/Neck Shape
Body Maximum Diameter cm
Body Height cm
Body Thickness cm
Body Surface Treatment
Body Decorative Treatment
Body Shape
Base Shape
Base Diameter cm
Base Height cm
Base Surface Treatment
Base Decorative Treatment
Notes

\section{$\mathrm{HW}$}

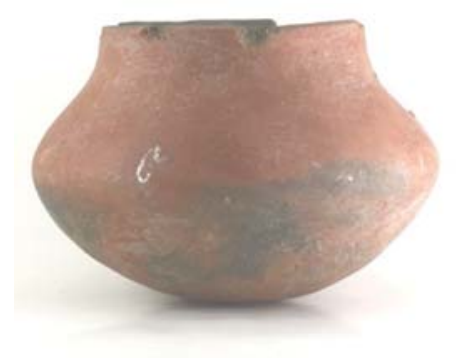

1-40

jar, short rim

N2494

sim to Smithport Plain

plain :: plain

HARD, SMOOTH, COMPACT

GROG \& GRIT (MICA, ABUNDANT)

5YR3/1

2.5YR5/6, 5YR5/4, 2.5YR2.5/1

2.5YR2.5/1

13

678

1.5

ABRASION ON BASE, BLACKENED INT BUT NO APPARENT SOOTING; FIRE CLOUDS ON EXT

JAR, SHORT RIM

FLAT, SLIGHTLY EVERTED

12.1

2.5

0.5

BURNISHED

RED COLORING LOOKS LIKE FIRING, NOT SLIP, BUT POSS RED OCHRE RUBBED

CONCAVE, INSLANTED

18.2

10.5

0.6

BURNISHED

RED COLOR LOOKS LIKE FIRING OR OCHRE RUBBED

SUBGLOBULAR

UNDISTINGUISHED, CONVEX

BURNISHED

PLAIN, TRACE RED COLOR

ASSOCIATED VESSEL - human bone found inside jar, no info on context 
JEC Hodges Collection, 77-1

East Place, 3CL21

Item No./Hodges Catalog

Vessel Form

AAS/HSU Digital Photo No.

Type

Decoration

Rim :: Body

Paste

Temper

Color, Core

Color, Exterior

Color, Interior

Overall Height cm

Weight g

Volume liters

Use/Wear/Condition

Shape / Description

Lip Treatment

Orifice Diameter cm

Rim Height cm

Rim Thickness cm

Rim Surface Treatment

Rim Decorative Treatment

Rim/Neck Shape

Body Maximum Diameter cm

Body Height cm

Body Thickness cm

Body Surface Treatment

Body Decorative Treatment

Body Shape

Base Shape

Base Diameter $\mathrm{cm}$

Base Height cm

Base Surface Treatment

Base Decorative Treatment Appendages

Notes

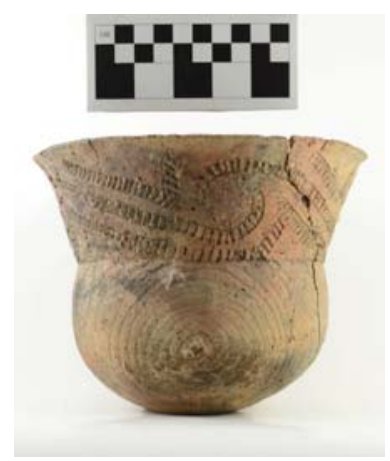

1-41, 1380 (Huddleston 201)

jar, tall rim

N2856

Cowhide/Foster Trailed-Incised

incised/punctated

Chatham 9 :: Baker 16? 21?

SOFT, SMOOTH, CRUMBLY

SHELL (LEACHED)

5 YR6/4

7.5YR6/4, 7.5YR4/1, 5YR5/6

5YR6/6, 5YR4/2, 5YR4/1

14.5

399

NONE; SOOTING INT RIM, EXT BODY; MISSING PC OF RIM, FILLED WITH PLASTER

JAR, TALL RIM

ROUNDED

19

8

0.4

SMOOTHED

INCISED, PUNCTATED (LADDER PUNCT)

STRAIGHT, OUTSLANTED

14.5

8

0.4

SMOOTHED

INCISED, NODES; CONCENTRIC CIRCLES WITH CENTRAL NODES,

TRAILED LINES

SUBGLOBULAR

CIRCULAR, FLAT/SLIGHTLY CONCAVE

5

SMOOTHED

NODES AS PART OF BODY DESIGN

Huddleston Grave 3?, 5/1939 (201=1380?), late Social Hill to Deceiper phase 
JEC Hodges Collection, 77-1

East Place, 3CL21

Item No./Hodges Catalog

Vessel Form

AAS/HSU Digital Photo No.

Type

Decoration

Rim :: Body

Paste

Temper

Color, Core

Color, Exterior

Color, Interior

Overall Height cm

Weight g

Volume liters

Use/Wear/Condition

Shape / Description

Lip Treatment

Orifice Diameter cm

Rim Height cm

Rim Thickness cm

Rim Surface Treatment

Rim Decorative Treatment

Rim/Neck Shape

Body Maximum Diameter $\mathrm{cm}$

Body Height cm

Body Thickness cm

Body Surface Treatment

Body Decorative Treatment

Body Shape

Base Shape

Base Diameter $\mathrm{cm}$

Base Height cm

Base Surface Treatment

Base Decorative Treatment Appendages

Notes

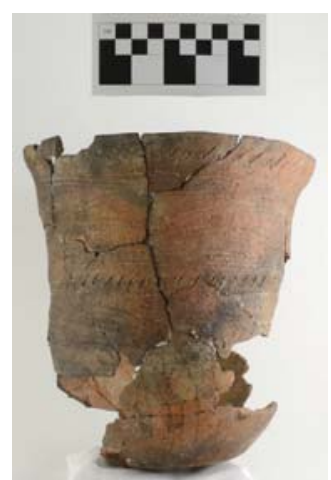

1-42, 1412 (Huddleston 224?) jar, tall rim

N3280

brushed/punctated

Dana 14 :: Danbury 2?

HARD, SMOOTH, COMPACT

SHELL (LEACHED)

7.5YR $4 / 1$

2.5YR5/6, 5YR3/1, 5YR6/6

5YR3/1, 5YR7/6, 7.5YR5/3

22

682

NONE NOTED; SOOTING RIM INT/EXT, FIRE CLOUDING; SHERD LOT RECONSTR., MISSING PC OF RIM \& ABOUT 1/3 OF BODY

JAR, TALL RIM

FLAT, SLIGHTLY EVERTED

21.4

9.8

SMOOTHED

BRUSHED \& PUNCTATED

CONCAVE, OUTSLANTED

18.4

12.2

0.5

SMOOTHED

BRUSHED

SUB-GLOBULAR

UNDISTINGUISHED, FLAT

8.5

SMOOTHED

Huddleston Grave 4, 5/27/1939 (with 1-35, 1-38, 1-39), late Mid-

Ouachita to Social Hill phase 
JEC Hodges Collection, 77-1

East Place, 3CL21

Item No./Hodges Catalog Vessel Form

AAS/HSU Digital Photo No.

Type

Decoration

Rim :: Body

Paste

Temper

Color, Core

Color, Exterior

Color, Interior

Overall Height cm

Weight g

Volume liters

Use/Wear/Condition

Shape / Description

Lip Treatment

Orifice Diameter $\mathrm{cm}$

Rim Height cm

Rim Thickness cm

Rim Surface Treatment

Rim Decorative Treatment

Rim/Neck Shape

Body Maximum Diameter cm

Body Height cm

Body Thickness cm

Body Surface Treatment

Body Decorative Treatment

Body Shape

Base Shape

Base Diameter cm

Base Height cm

Base Surface Treatment

Base Decorative Treatment

Appendages

Notes

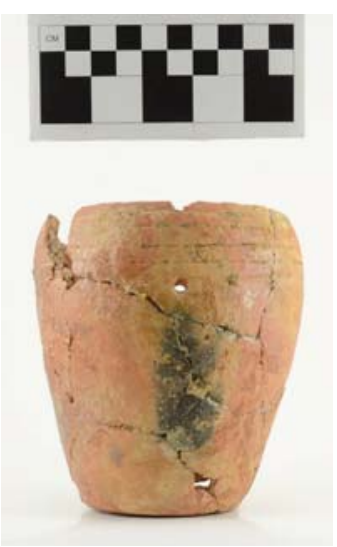

1-43, 2747

beaker

N3034

East Incised

incised

Bates 17? :: plain

HARD, SMOOTH, COMPACT

GROG

7.5YR2.5/1, 2.5YR5/8

2.5YR5/6, 7.5YR7/4, 10YR3/1

$2.5 \mathrm{YR} 5 / 6$

13

403

FIRE CLOUDING; MISSING MORE THAN 1/2 RIM AND SHERDS FROM RIM \& BODY

BEAKER

ROUNDED

11.5

3

0.5

BURNISHED

INCISED \& RED SLIP; 5 INCISED LINES BELOW LIP, 5-8MM APART, SUSPENSION HOLE

PARTLY SMOOTHED OVER, SOMEWHAT MEANDERING

CONVEX, INSLANTED

11.5

10

0.5

BURNISHED

RED SLIP

HIGH WAISTED

CIRCULAR, FLAT?

7.1

BURNISHED

RED SLIP

Huddleston Grave F, 1/1/1943 (with 1-8, 1-24, 1-29, 1-44?), East phase 
JEC Hodges Collection, 77-1 East Place, 3CL21

Item No./Hodges Catalog Vessel Form

AAS/HSU Digital Photo No.

Type

Decoration

Rim :: Body

Paste

Temper

Color, Core

Color, Exterior

Color, Interior

Overall Height cm

Weight g

Volume liters

Use/Wear/Condition

Shape / Description

Lip Treatment

Orifice Diameter $\mathrm{cm}$

Rim Height cm

Rim Thickness cm

Rim Surface Treatment

Rim Decorative Treatment

Rim/Neck Shape

Body Maximum Diameter cm

Body Height cm

Body Thickness cm

Body Surface Treatment

Body Decorative Treatment

Body Shape

Base Shape

Base Diameter cm

Base Height cm

Base Surface Treatment

Base Decorative Treatment Appendages

Notes

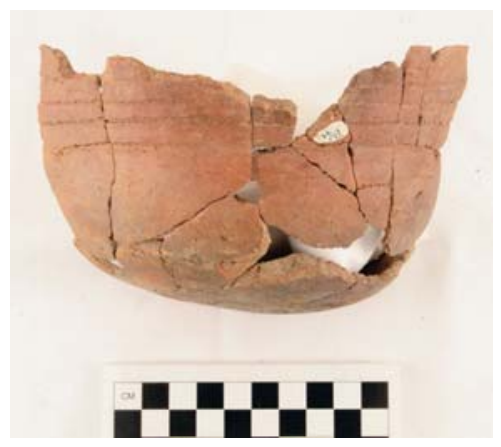

1-44, 2746

bowl

N4840

East Incised

incised

Bates 3 or Barrington 1 :: plain

HARD, SMOOTH, COMPACT

GROG, MEDIUM, ABUNDANT

7.5YR4/1

7.5YR4/2, 7.5YR3/2

7.5YR4/2, 7.5YR2.5/1, 7.5YR5/3

9.5

156

SOME ROGHENING BASE INT/EXT, SOME SOOTING OR BLACK RESIDUE ON BASE INT/EXT, SHERD LOT WAS PARTIALLY RECONSTR., ABOUT 25\% PRESENT

BOWL, OUTSLANTED RIM

SMOOTHED, FLAT LIP, THINNED

14 (est., 25\%)

3.4

0.3

BURNISHED

5 HORIZONTAL LINES, INCISED, SMOOTHED OVER, 6-8mm APART STRAIGHT, OUTSLANTED

6.1

0.3

BURNISHED

PLAIN

CONVEX

UNDISTINGUISHED

BURNISHED/ERODED

Huddleston Grave F, 1/1/1943 (with 1-8, 1-24, 1-29, 1-43), East phase 
JEC Hodges Collection, 77-1

East Place, 3CL21

Item No./Hodges Catalog

Vessel Form

AAS/HSU Digital Photo No.

Type

Decoration

Rim :: Body

Paste

Temper

Color, Core

Color, Exterior

Color, Interior

Overall Height cm

Weight g

Volume liters

Use/Wear/Condition

Shape / Description

Lip Treatment

Orifice Diameter $\mathrm{cm}$

Rim Height cm

Rim Thickness cm

Rim Surface Treatment

Rim Decorative Treatment

Rim/Neck Shape

Body Maximum Diameter cm

Body Height cm

Body Thickness cm

Body Surface Treatment

Body Decorative Treatment

Body Shape

Base Shape

Base Diameter cm

Base Height cm

Base Surface Treatment

Base Decorative Treatment

Appendages

Notes

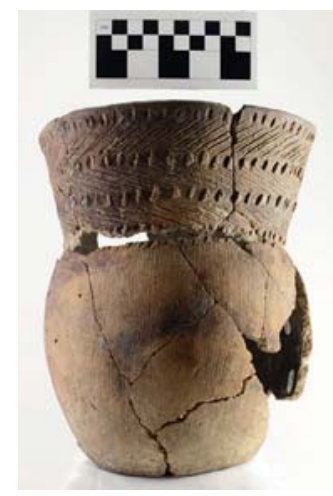

1-46, 2691

jar, tall rim

N4800

punctated/brushed

Andes? :: Danbury 1

HARD, SMOOTH, COMPACT

GROG, MEDIUM, ABUNDANT

$7.5 \mathrm{YR} 5 / 2$

7.5YR5/2, 7.5YR2.5/1, 7.5YR5/6

7.5YR2.5/1, 7.5YR6/3

21.1

1092

FIRECLOUDING, SOME SOOTING ON BODY EXT \& INT, RECONSTR FROM SHERD LOT, PARTIAL VESSEL

JAR, TALL RIM

SMOOTHED, FLAT/BEVELED EXT. LIP, SLIGHTLY EVERTED

17.8

7.1

0.7

SMOOTHED

ROWS OF FINGERNAIL PUNCTATES W/ DIAG. INCISING IN BETWEEN

STRAIGHT, OUTSLANTED

17.3

14

0.8

SMOOTHED

VERTICAL BRUSHING OR COMBING, NOT OVERLAPPING, REGULAR

CLOSESPACED VERT LINES

SUBGLOBULAR

CIRCULAR, FLAT

10

SMOOTHED

Huddleston Grave A', 11/14/1942 (with 1-4, 1-19, 1-30, 1-31), East phase 
JEC Hodges Collection, 77-1

East Place, 3CL21

Item No./Hodges Catalog

Vessel Form

AAS/HSU Digital Photo No.

Type

Decoration

Rim :: Body

Paste

Temper

Color, Core

Color, Exterior

Color, Interior

Overall Height cm

Weight g

Volume liters

Use/Wear/Condition

Shape / Description

Lip Treatment

Orifice Diameter cm

Rim Height cm

Rim Thickness cm

Rim Surface Treatment

Rim Decorative Treatment

Rim/Neck Shape

Body Maximum Diameter cm

Body Height cm

Body Thickness cm

Body Surface Treatment

Body Decorative Treatment

Body Shape

Base Shape

Base Diameter cm

Base Height cm

Base Surface Treatment

Base Decorative Treatment

Appendages

Notes

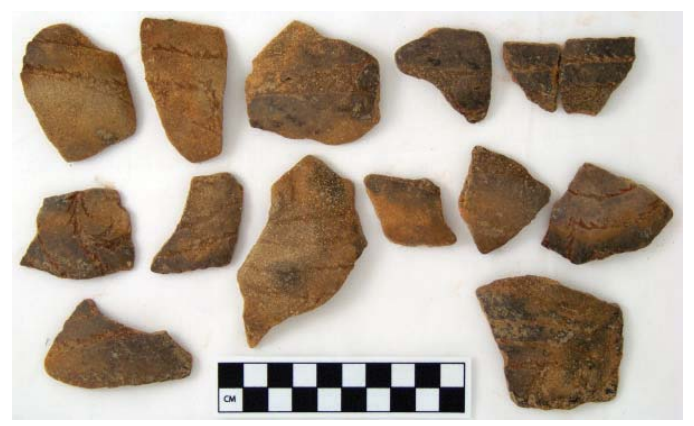

$1-47,2513$

bottle

K7166

engraved

plain :: Elmira 60? Elmhurst 9?

SOFT, GRITTY, CRUMBLY

GROG

$5 \mathrm{YR} 6 / 6$

5YR6/6, 5YR4/1, 5YR5/6

5YR6/6, 5YR5/6

SHERD LOT, NOT RECONSTRUCTED

BOTTLE, SHORT WIDE NECK - SHERD LOT, NOT RECONSTRUCTED

ROUNDED

5.4

5.7

0.3

ERODED

INSLOPING

0.4

ENGRAVED, RED PIGMENT IN LINES

ERODED

Huddleston Grave X or Y, 12/6/1941 (with 1-23), Mid-Ouachita phase 
JEC Hodges Collection, 77-1

East Place, 3CL21

Item No./Hodges Catalog

Vessel Form

AAS/HSU Digital Photo No.

Type

Decoration

Rim :: Body

Paste

Temper

Color, Core

Color, Exterior

Color, Interior

Overall Height cm

Weight g

Volume liters

Use/Wear/Condition

Shape / Description

Lip Treatment

Orifice Diameter $\mathrm{cm}$

Rim Height cm

Rim Thickness cm

Rim Surface Treatment

Rim Decorative Treatment

Rim/Neck Shape

Body Maximum Diameter cm

Body Height cm

Body Thickness cm

Body Surface Treatment

Body Decorative Treatment

Body Shape

Base Shape

Base Diameter cm

Base Height cm

Base Surface Treatment

Base Decorative Treatment

Appendages

Notes

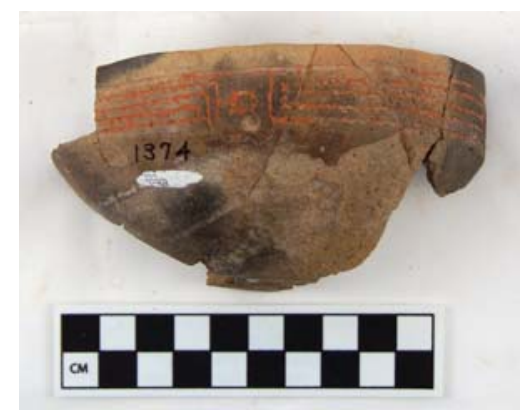

1-48, 1374 (Huddleston 197)

bowl, carinated

K7170

Means Engraved

engraved

Erie 1 :: Enos 9?

HARD, SMOOTH, COMPACT

SHELL (LEACHED) \& GROG

10YR3/1, 10YR6/2, 5YR7/6

10YR8/3, 10YR3/1

5.5

SPALLING ON BODY; FIRECLOUDING; WAS SHERD LOT, MISSING ABOUT 1/2 RIM AND MORE THAN 1/2 BODY AND BASE

CARINATED BOWL

ROUNDED

12.6

2

0.3

BURNISHED

ENGRAVED W/ RED PIGMENT, RECT. DESIGN OF SPURRED LINES

STRAIGHT, VERTICAL

3.5

0.35

BURNISHED

CONVEX

CIRCULAR, FLAT

\section{ENGRAVED CONCENTRIC CIRCLES}

Huddleston Grave 1 or 2, 4/29/1939 (with 1-12, 1-36, 1-49), late Social Hill to Deceiper phase; Phillips photo 3886 
JEC Hodges Collection, 77-1

East Place, 3CL21

Item No./Hodges Catalog

Vessel Form

AAS/HSU Digital Photo No.

Type

Decoration

Rim :: Body

Paste

Temper

Color, Core

Color, Exterior

Color, Interior

Overall Height $\mathrm{cm}$

Weight g

Volume liters

Use/Wear/Condition

Shape / Description

Lip Treatment

Orifice Diameter cm

Rim Height cm

Rim Thickness cm

Rim Surface Treatment

Rim Decorative Treatment

Rim/Neck Shape

Body Maximum Diameter cm

Body Height cm

Body Thickness cm

Body Surface Treatment

Body Decorative Treatment

Body Shape

Base Shape

Base Diameter cm

Base Height cm

Base Surface Treatment

Base Decorative Treatment Appendages

Notes

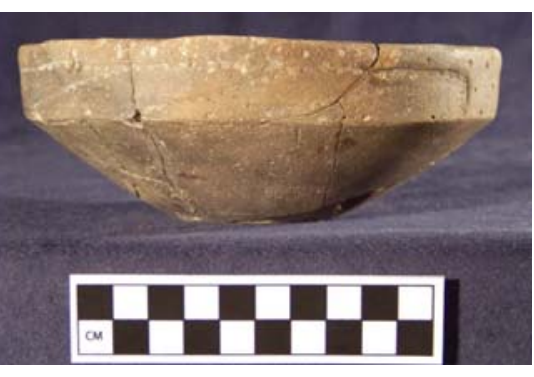

1-49, 1375 (Huddleston 198)

bowl, carinated

K5219

Means Engraved

engraved

Enos 4? 5? :: plain

HARD, SMOOTH, COMPACT

GROG \& SHELL (LEACHED)

7.5YR4/2

$7.5 \mathrm{YR} 4 / 2$

6

281

0.6

LARGE CHIP ON LIP

CARINATED BOWL

ROUNDED

16.6

2.4

0.582

BURNISHED

ENGRAVED WITH PUNCTATES

STRAIGHT, VERTICAL

6.5

3.6

0.5

BURNISHED

CONVEX

CIRCULAR, CONCAVE

5

BURNISHED

Huddleston Grave 1 or 2, 4/29/1939 (with 1-12, 1-36, 1-48), late Social Hill to Deceiper phase; Phillips photo 3871 
JEC Hodges Collection, 77-1

East Place, 3CL21

Item No./Hodges Catalog

Vessel Form

AAS/HSU Digital Photo No.

Type

Decoration

Rim :: Body

Paste

Temper

Color, Core

Color, Exterior

Color, Interior

Overall Height cm

Weight g

Volume liters

Use/Wear/Condition

Shape / Description

Lip Treatment

Orifice Diameter $\mathrm{cm}$

Rim Height cm

Rim Thickness cm

Rim Surface Treatment

Rim Decorative Treatment

Rim/Neck Shape

Body Maximum Diameter cm

Body Height cm

Body Thickness cm

Body Surface Treatment

Body Decorative Treatment

Body Shape

Base Shape

Base Diameter cm

Base Height cm

Base Surface Treatment

Base Decorative Treatment

Appendages

Notes

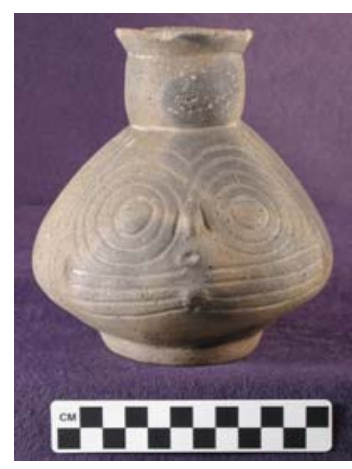

1-50, 1372 (Huddleston 208)

effigy bottle, pedestalled

427

Keno Trailed

incised/trailed/modeled/effigy

plain :: Baker 27?

SOFT, COMPACT

SHELL (LEACHED)

LIGHT GRAY (10YR8/1)

GRAY-SOME FIRECLOUDING (10YR4/2)

GRAY (10YR4/1)

14.7

412.2

SOME LIP DAMAGE, PROBABLY POST-DEPOSITIONAL

BOTTLE, HUMAN FACE EFFIGY, PEDESTAL

FLARED

6.2

4.2

.5

SMOOTHED

SPOOL

13.7

9.7

SMOOTHED

WIDE LINE INCISING/TRAILING AND SURFACE MODELING (NODES)

2 HUMAN FACE EFFIGIES ON 2 PANELS WITH VERTICAL LINES IN

BETWEEN

SUB-GLOBULAR-MAXIMUM WIDTH IS LOW

CIRCULAR, FLAT, PEDESTAL

7.0

.8

Huddleston Grave 3, 4/29-5/5/1939 (with 1-13, 1-32, 1-34, 1-41?), late Social Hill to Deceiper phase; Huddleston sketch in notebook; Phillips photo 3857; previous illustration Suhm \& Jelks 1962: Plate 44K 